SJ Quinney College of Law, University of Utah Utah Law Digital Commons

Utah Law Faculty Scholarship

Utah Law Scholarship

$10-2016$

\title{
2016 Trying Times: Important Lessons to Be Learned from Recent Federal Tax Cases
}

Nancy McLaughlin

S.J. Quinney College of Law, University of Utah, nancy.mclaughlin@law.utah.edu

Follow this and additional works at: http://dc.law.utah.edu/scholarship

Part of the Property Law and Real Estate Commons, Taxation-Federal Estate and Gift Commons, and the Tax Law Commons

\section{Recommended Citation}

McLaughlin, Nancy, "2016 Trying Times: Important Lessons to Be Learned from Recent Federal Tax Cases" (2016). Utah Law Faculty Scholarship. 50.

http://dc.law.utah.edu/scholarship/50

This Article is brought to you for free and open access by the Utah Law Scholarship at Utah Law Digital Commons. It has been accepted for inclusion in Utah Law Faculty Scholarship by an authorized administrator of Utah Law Digital Commons. For more information, please contact

valeri.craigle@law.utah.edu. 


\title{
TRYING TIMES
}

\section{IMPORTANT LESSONS TO BE LEARNED FROM FEDERAL TAX CASES InVOLVING CONSERVATION EASEMENT DONATIONS}

\author{
ACTEC 2016 Fall MeEting \\ Belmond Charleston Place Hotel \\ State LaWs CoMmitTEe \\ OCTOBER 20, 2016
}

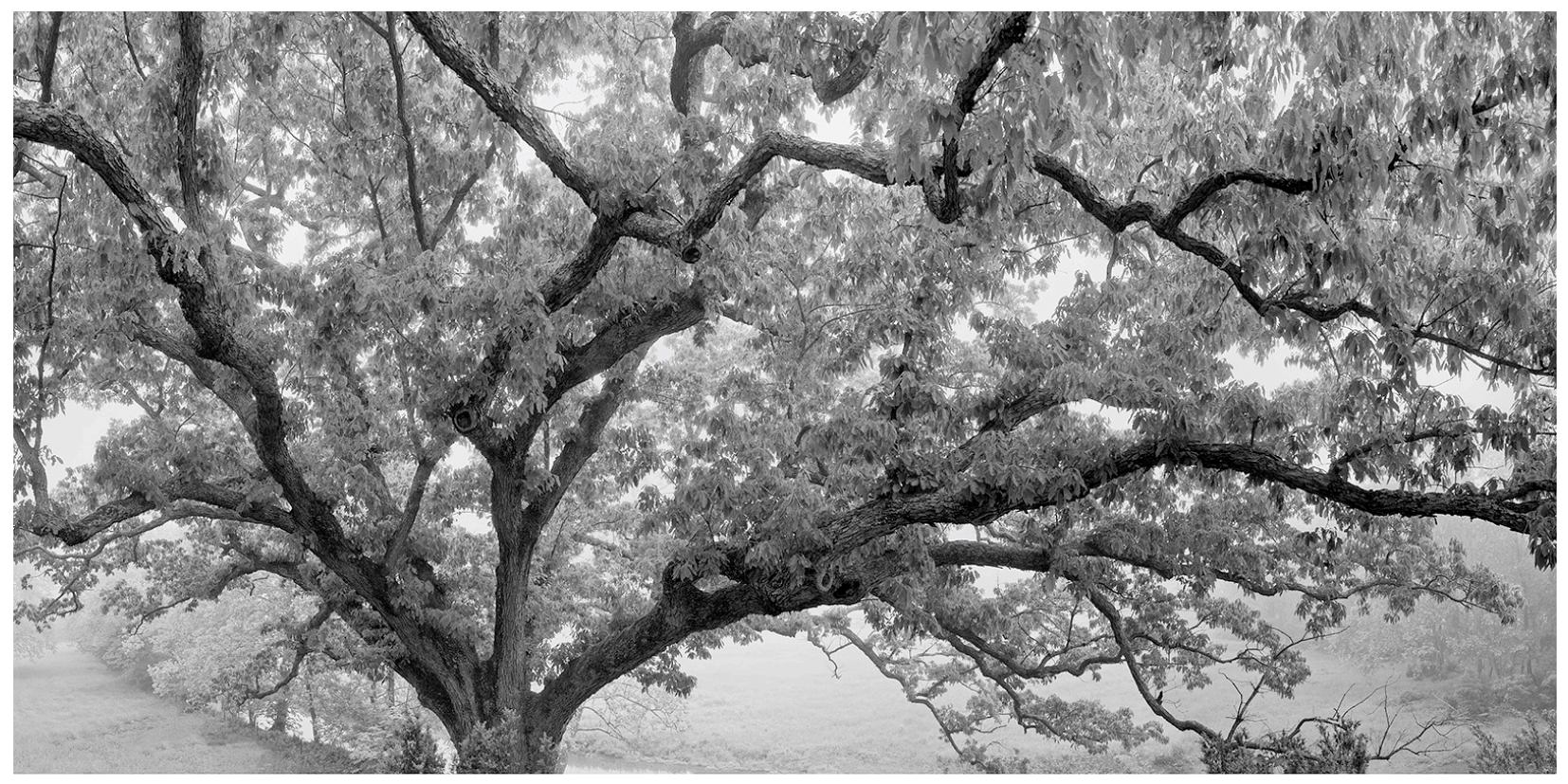

by

Nancy A. McLaughlin

Robert W. Swenson Professor of Law

University of Utah S.J. Quinney College of Law

Salt Lake City, Utah 84108

nancy.mclaughlin@law.utah.edu

This outline is a version of the outline prepared by Nancy A. McLaughlin and Stephen J. Small for presentations at the Land Trust Alliance annual national conferences. This outline intended for educational and informational purposes only. Nothing in this outline is to be considered the rendering of legal advice. Readers are responsible for obtaining legal advice from their own legal counsel.

(C2016 by Nancy A. McLaughlin \& Stephen J. Small, All Rights Reserved. 


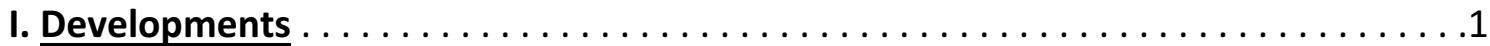

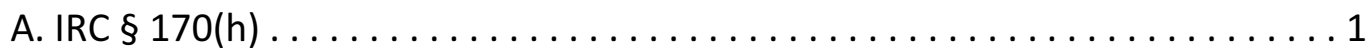

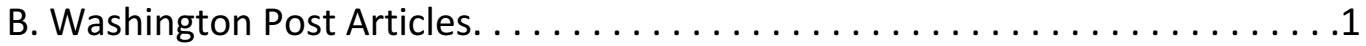

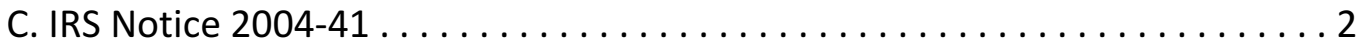

D. 2005 Joint Committee on Taxation Report. . . . . . . . . . . . . . . . 2

E. Proposal to Penalize Charities that Remove or Fail to Enforce Easements. . . .2

F. 2005 Senate Finance Committee Report. . . . . . . . . . . . . . . . . . . 3

G. 2005 IRS Testimony Before Senate Finance Committee . . . . . . . . . . . 4

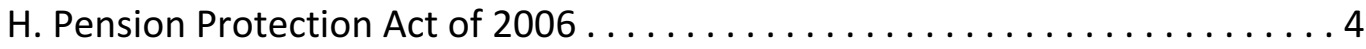

I. DOJ Suit Against Trust for Architectural Easements. . . . . . . . . . . . . .4

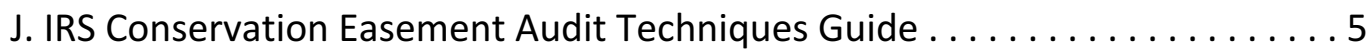

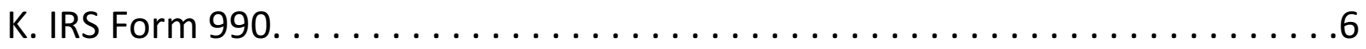

L. Administration's Fiscal Year 2013 Revenue Proposals . . . . . . . . . . . . . . 6

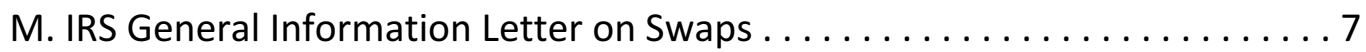

N. IRS General Information Letter on Extinguishment . . . . . . . . . . . . .7

O. DOJ Suit Against Façade Easement Appraiser. . . . . . . . . . . . . . . . . .7

P. Administration's Fiscal Year 2014 Revenue Proposals. . . . . . . . . . . . . . 8

Q. IRS Chief Counsel Advice on Conservation Easement Valuation. . . . . . . . .8

R. Administration's Fiscal Year 2015 Revenue Proposals. . . . . . . . . . . . . . . 9

S. IRS Bars Appraisers From Valuing Easements for Five Years. . . . . . . . . . . 9

T. Administration's Fiscal Year 2016 Revenue Proposals . . . . . . . . . . . . . . 10

U. Enhanced Incentives Made Permanent Without Modifications . . . . . . . . . 10

V. Administration's Fiscal Year 2017 Revenue Proposals. . . . . . . . . . . . . . 11

W. Broad IRS Summons Served on Appraiser and CPA . . . . . . . . . . . 11

X. Treasury's 2016-2017 Priority Guidance Plan. . . . . . . . . . . . . . . . 12

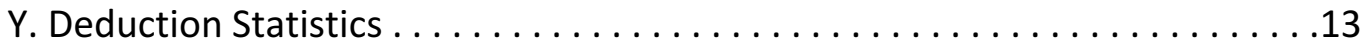

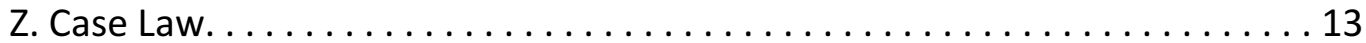

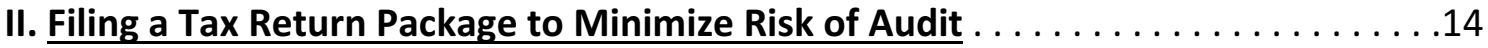

A. Correctly Drafted Conservation Easement Deed. . . . . . . . . . . . . . . . . 14

1. Copy of Final Conservation Easement Deed

2. Extensive Recitals

3. "Exclusively for Conservation Purposes"

4. Reserved Rights

5. The Conservation Purposes Test

6. Extinguishment Requires Judicial Proceeding

7. Swaps Are Prohibited

8. State Law Can Render Conservation Easements Nondeductible

9. Interaction Between Federal and State Law

10. Benefits of Restricted Gift Status

11. Sample Restriction on Transfer and Extinguishment Clauses

12. "Greater of" Proceeds Formula 
13. Noncompliant "Proceeds" Clause

14. Reimbursement of Funders on Extinguishment

B. Qualified Appraisal and IRS Form 8283 (Appraisal Summary)

1. Short History

2. Form 8283, Section B

3. Supplemental Statement

4. Special Rules for Façade Easement Donations

C. Qualified Appraisal Requirements

1. General Requirements

2. Conservation Easement-Specific Valuation Rules

3. File Qualified Appraisal with Income Tax Return

D. Contemporaneous Written Acknowledgment. . . . . . . . . . . . . . 55

E. Compelling and Timely Baseline Documentation . . . . . . . . . . . . . 56

F. Correct and Timely Lender Agreement (if applicable). . . . . . . . . . . . . 58

1. Full Subordination is Advisable

2. Mortgages Must be Subordinated at Time of Donation

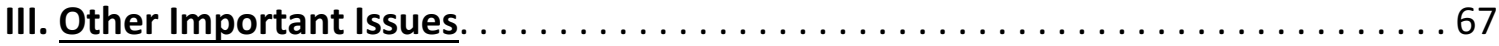

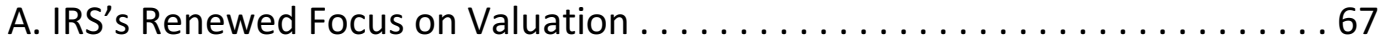

1. Penalty Provisions

2. Battle of the Appraisers

3. Valuation Case Law

B. IRS's Focus on Partnerships/Syndicated Deals.

1. IRS Weapons

2. Land Trust Alliance on Syndicated Deals

C. Date of Donation and Recordation Date.

1. IRS's Position on Recordation

2. Case Law

3. The Finer Points of Delivery and Recording

D. Quid Pro Quo.......................................... 80

1. Pollard

2. Seventeen Seventy Sherman Street

3. Costello

4. Pesky

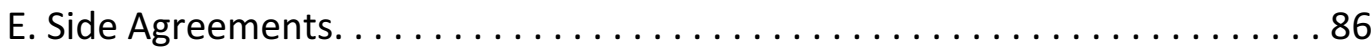

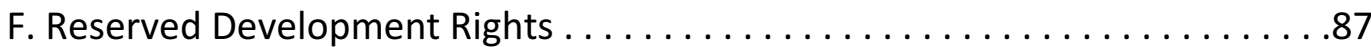

G. PLRs Recommending Revocation of Tax-Exempt Status. . . . . . . . . . . 90

H. State Tax Credits . . . . . . . . . . . . . . . . . . . . . . . 91

1. Tax Treatment of Sale of State Tax Credits

2. Nonpro rata Allocation of State Tax Credits was Disguised Sale

Appendices

Appendix A: IRC § 170(h)

Appendix B: Treasury Regulation $\S 1.170 \mathrm{~A}-14$ 
Appendix C: Table of Deduction Cases

Appendix D: Treasury Regulation $\S 1.170 \mathrm{~A}-13(\mathrm{c})$

Appendix E: IRC \& 170(f)(11)

Appendix F: Form 8283 Examples

Appendix G: Form 8283 Supplemental Statement Example

Appendix H: Blog Posts 


\section{Developments}

\section{A. IRC § 170(h)}

1. IRC $\S 170(\mathrm{~h})$ (attached as Appendix A), which authorizes a federal charitable income tax deduction for the donation of a conservation easement meeting specific requirements, was enacted in 1980.

2. Treasury Regulations interpreting $\S 170(\mathrm{~h})$ (attached as Appendix B) were issued in $1986 .^{1}$

3. The Treasury Regulations are based, in large part, on the Senate Report describing $\S 170(\mathrm{~h})$ (referred to as legislative history). ${ }^{2}$

\section{B. Washington Post Articles}

In May 2003, the Washington Post published a series of articles questioning some of the practices of The Nature Conservancy. ${ }^{3}$ In December of that same year, the Washington Post published a follow-up article describing allegedly abusive conservation easement donation transactions involving "wildly exaggerated" easement appraisals and developers who received "shocking" tax deductions for donating conservation easements encumbering golf course fairways or otherwise undevelopable land. ${ }^{4}$

In December 2004, the Washington Post published a second series of articles alleging abuses in the facade easement donation context. ${ }^{5}$ The articles described a surge in facade easement donations that coincided with the emergence of for-profit facilitators and nonprofit organizations that have "taken in millions of dollars for processing paperwork and monitoring the easements." The articles also noted that facade easements often merely duplicate restrictions already imposed by local law and fail to decrease the value of the buildings they encumber, making the tax deductions based on a $10 \%$ to $15 \%$ reduction in the value of the properties unwarranted. One promoter reportedly told property owners they would receive tax breaks for a drop in their property values, but stressed that there would be no actual decline; that "[i]t's a paper concept." 6

\footnotetext{
${ }^{1}$ Treas. Reg. § 1.170A-14.

${ }^{2}$ S. Rep. No. 96-1007 (1980).

${ }^{3}$ See David B. Ottaway \& Joe Stephens, Nonprofit Land Bank Amasses Billions, WASH. Post, May 4, 2003, at A1; Joe Stephens \& David B. Ottaway, How a Bid to Save a Species Came to Grief, WASH. Post, May 5, 2003, at A1; Joe Stephens \& David B. Ottaway, Nonprofit Sells Scenic Acreage to Allies at a Loss; Buyers Gain Tax Breaks with Few Curbs on Land Use, WASH. POST, May 6, 2003, at A1.

4 Joe Stephens \& David B. Ottaway, Developers Find Payoff in Preservation, WASH. Post, Dec. 21, 2003, at A1.

${ }^{5}$ See Joe Stephens, For Owners of Upscale Homes, Loophole Pays; Pledging to Retain the Facade Affords a Charitable Deduction, WASH. POST, Dec. 12, 2004, at A1 [Loophole Pays]; Joe Stephens, Local Laws Already Bar Alterations; Intervention by Trusts Is Rare for Preservation, WASH. POST, Dec. 12, 2004, at A15; Joe Stephens, Tax Break Turns Into Big Business, WASH. Post, Dec. 13, 2004, at A1.

${ }^{6}$ See Loophole Pays, supra note 5.
} 


\section{IRS Notice 2004-41}

In June 2004, the IRS issued Notice 2004-41 stating that the IRS is aware that taxpayers who transfer conservation easements to charitable organizations or make payments to charitable organizations in connection with a purchase of real property from the organization may be improperly claiming charitable deductions under $\S 170{ }^{7}$ The Notice warned that the IRS intends to disallow improper deductions and impose penalties and excise taxes on taxpayers, promoters, and appraisers involved in such transactions.

\section{2005 Joint Committee on Taxation Report}

In January 2005, the Joint Committee on Taxation issued a report to Congress recommending, among other things, that

1. the federal charitable income tax deduction offered to conservation easement donors be eliminated with respect to easements encumbering property on which the donor maintains a personal residence,

2. the deduction be substantially reduced in all other cases, and

3. new standards be imposed on appraisers and appraisals with regard to the valuation of easements. ${ }^{8}$

\section{E. Proposal to Penalize Charities that Remove or Fail to Enforce Easements}

In March 2005, the Joint Committee on Taxation published a Description of Revenue Provisions Contained in the President's Fiscal Year 2006 Budget Proposal, one of which was to impose significant penalties on any charity that removes or fails to enforce a conservation easement, or transfers such an easement without ensuring that the conservation purposes will be protected in perpetuity. ${ }^{9}$ The proposal was intended to address the concern that charitable contributions of conservation easements, which are required to be in perpetuity, are being removed, or are being transferred without securing the conservation purpose.

\footnotetext{
${ }^{7}$ IRS Notice 2004-41 is available at http://www.irs.gov/irb/2004-28_IRB/ar09.html.

${ }^{8}$ See Options to Improve Tax Compliance and Reform Tax Expenditures, prepared by the JCT, JCS-2-05, 281 (Jan. 27, 2005), available at http://www.jct.gov/publications.html?func=showdown\&id=1524.

${ }^{9}$ See Description of Revenue Provisions Contained in the President's Fiscal Year 2006 Budget Proposal, prepared by the JCT, JCS-3-05, 239-41 (March 2005), available at https://www.jct.gov/publications.html?func=startdown\&id=1523.
} 


\section{F. 2005 Senate Finance Committee Report}

In June 2005, the Senate Finance Committee held a hearing on the federal tax incentives available with respect to conservation easement donations. In connection with that hearing, the Senate Finance Committee issued a report in which it recommended numerous reforms, including:

1. revocation of the tax-exempt status of conservation organizations that regularly and continuously fail to monitor the conservation easements they hold (or the suspension of the ability of such organizations to accept tax-deductible contributions),

2. implementation of an accreditation program for conservation organizations acquiring easements,

3. limiting charitable contribution deductions for certain small easement donations and providing the IRS with the authority to pre-approve deductions for such donations, and

4. IRS issuance of guidance regarding how a conservation organization can establish that it is appropriately monitoring the easements it holds. ${ }^{10}$

The Senate Finance Committee report also expresses concern regarding amendments to conservation easements. The report explains that "[m]odifications to an easement held by a conservation organization may diminish or negate the intended conservation benefits, and violate the present law requirements that a conservation restriction remain in perpetuity." ${ }^{11}$ The report notes that modifications made to correct ministerial or administrative errors are permitted under present federal tax law. ${ }^{12}$ But the report expresses concern with regard to "trade-off" amendments, which both negatively impact and further the conservation purpose of an easement, but on balance are arguably either neutral with respect to or enhance such purpose. ${ }^{13}$ The report provides, as an example, an amendment to an easement that would permit the owner of the encumbered land to construct a larger home in exchange for restrictions further limiting the use of the land for agricultural purposes. ${ }^{14}$ The report explains that trade-off amendments "may be difficult to measure from a conservation perspective," and that the "weighing of increases and decreases [in conservation benefits] is difficult to perform by [the holder] and to assess by the IRS." 15

\footnotetext{
${ }^{10}$ See Report of Staff Investigation of The Nature Conservancy (Volume I), U.S. Senate Committee on Finance, Executive Summary 10-11 (June 2005), available under "Library," then "Committee Prints" at http://finance.senate.gov/.

${ }^{11}$ Id., Executive Summary 9.

${ }^{12}$ Id., Executive Summary 9, n. 20.

${ }^{13}$ See id. at Pt. II 5.

${ }^{14}$ See id.

${ }^{15}$ Id.
} 


\section{G. 2005 IRS Testimony Before Senate Finance Committee}

In his testimony before the Senate Finance Committee in June 2005, then IRS Commissioner of the Tax-Exempt and Government Entities Division, Steven T. Miller, discussed the steps the IRS was taking to enforce the law in this area. Such steps included

1. modifications to IRS Forms 1023,990 , and 8283 ,

2. the formation of a special cross-functional team to "attack all aspects of the problem of conservation easements," and

3. increased audits of easement donors. ${ }^{16}$

\section{H. Pension Protection Act of $\mathbf{2 0 0 6}$}

To combat abuses, the Pension Protection Act of 2006, ${ }^{17}$ among other things,

1. revised the rules in $\S 170(\mathrm{~h})$ with respect to contributions of façade easements,

2. provided statutory definitions of the terms "qualified appraiser" and "qualified appraisal" in IRC § 170(f)(11), and

3. lowered the thresholds for accuracy-related penalties and made the gross valuation misstatement penalty with regard to charitable contributions a strict liability penalty (see Part III.A below).

At the same time, the Pension Protection Act increased the tax benefits offered to conservation easement donors for donations made in 2006 and 2007 by making the percentage limitations on the resulting charitable deductions more favorable. ${ }^{18}$ These enhanced incentives were repeatedly temporarily extended and then made permanent in 2015 (see Part I.U below).

\section{DOJ Suit Against Trust For Architectural Easements}

In June 2011, the Department of Justice filed a lawsuit against the Trust for Architectural Easements ("TAE"). ${ }^{19}$ The lawsuit alleged, among other things, that TAE made false and fraudulent statements to prospective donors about the tax benefits available for donating façade easements, steered donors to appraisers who had been coached by it to go along with its questionable practices, helped donors to claim deductions before donations were final, and allowed donors to terminate easements they had already

\footnotetext{
${ }^{16}$ The testimony is available at http://www.finance.senate.gov/hearings/hearing/?id=e821cece-d9eb-1c66-4b9eb4a6602a54f4.

${ }^{17}$ Pub. L. No. 109-280, 120 Stat. 780.

${ }^{18}$ For an explanation of these changes, see Technical Explanation Of H.R. 4, The "Pension Protection Act Of 2006," prepared by the JCT, JCX-38-06 (August 3, 2006), available at

https://www.jct.gov/publications.html?func=select\&id=20.

${ }^{19}$ Complaint for Permanent Injunction and Other Relief, U.S. v. McClain, Civ. No. 11-1087 (U.S. Dist. Ct. D.C. June 14, 2011). TAE was formerly known as the National Architectural Trust or "NAT."
} 
granted. ${ }^{20}$ In July 2011, a U.S. District Court Judge issued a permanent injunction against TAE settling the case. ${ }^{21}$ The injunction permanently prohibits TAE from engaging in what the federal government said were abusive and illegal practices. The injunction bars TAE from, among other things:

1. representing to prospective donors and others that the IRS has established a "safe harbor" for the value of a donated façade easement equal to 10 to $15 \%$ of the subject building's value,

2. participating in the appraisal process for a conservation easement in any regard, including recommending or referring donors to an appraiser or TAE's preferred list of appraisers,

3. accepting easements that lack a conservation purpose or do not satisfy the "protected in perpetuity" requirement of $\S 170(\mathrm{~h})$, and

4. requesting fees or cash donations tied to a percentage of the estimated value of the easement or the deduction to be claimed with regard to the easement's donation.

TAE was also ordered to pay an independent monitor for two years to ensure that it complied with the injunction. The injunction did not preclude the IRS from assessing penalties against TAE for violations of the Internal Revenue Code. The injunction also did not address whether TAE was entitled to retain its tax-exempt status. ${ }^{22}$

\section{J. IRS Conservation Easement Audit Techniques Guide}

The IRS has issued a Conservation Easement Audit Techniques Guide. ${ }^{23}$ The Guide provides that it is not an official pronouncement of the law or the position of the IRS, and it cannot be used, cited, or relied upon as such. The Guide nonetheless provides a summary of many of the requirements that must be met to be eligible for a federal charitable income tax deduction for the donation of a conservation easement under $\S 170(\mathrm{~h})$. The Guide also alerts readers to issues that may be considered and raised on audit. The IRS has informally indicated that the Guide will be periodically updated to reflect case law and other developments.

\footnotetext{
${ }^{20}$ Id. See also Janet Novack, Feds Sue Trust Over Historic Easement Tax Breaks, Taxing Matters, FoRBES, June 16, 2011.

${ }^{21}$ Stipulated Order of Permanent Injunction, U.S. v. McClain, Civ. No. 11-1087 (U.S. Dist. Ct. D.C. July, 15, 2011) (TAE agreed to the settlement without admitting any wrongdoing).

${ }^{22}$ Id. See also D.C. Federal Court Bars Company from Promoting Alleged Tax Scheme Involving Improper Easements on Historic Buildings, Department of Justice Press Release (July 18, 2011), available at http://www.justice.gov/opa/pr/2011/July/11-tax-933.html; Joe Stephens, Judge bars D.C. charity from promoting 'façade easement' tax deductions, WASH. POST, July 19, 2011.

${ }^{23}$ See http://www.irs.gov/Businesses/Small-Businesses-\&-Self-Employed/Conservation-Easement-Audit-TechniquesGuide [hereinafter IRS CE Audit Techniques Guide].
} 


\section{K. IRS Form 990}

IRC $\S 501(c)(3)$ organizations-as most land trusts are-must file an IRS Form 990 (Return of Organization Exempt From Income Tax) each year. ${ }^{24}$ Schedule D to IRS Form 990 requires a charitable organization holding a conservation easement to provide certain information, including:

1. the total number of conservation easements held at the end of the year;

2. the total acreage restricted by such easements;

3. the number of easements modified, transferred, released, or extinguished, by the organization during the taxable year;

4. whether the organization has a written policy regarding the monitoring and enforcement of easements;

5. the total number of hours devoted to monitoring, enforcing, and inspecting conservation easements during the tax year; and

6. the expenses incurred during the tax year to monitor, inspect, and enforce easements.

For each easement modified, transferred, released, or extinguished, in whole or in part, the organization must explain the changes in a Supplemental Statement to Schedule D. The Instructions for Schedule D explain:

1. an easement is released, extinguished, or terminated when, among other things, all or part of the property subject to the easement is removed from the protection of the easement in exchange for cash or the protection of some other property,

2. the use of synonyms does not avoid the application of the reporting requirement (e.g., calling an action a "swap" or a "boundary line adjustment" does not mean the action is not also a modification, transfer, or extinguishment), and

3. "[t]ax exemption may be undermined by the modification, transfer, release, extinguishment, or termination of an easement." ${ }^{25}$

\section{Administration's Fiscal Year 2013 Revenue Proposals}

In February 2012, the Treasury Department published General Explanations of the Administration's Fiscal Year 2013 Revenue Proposals. These proposals included a proposal to eliminate the charitable deduction for contributions of conservation easements on golf courses. ${ }^{26}$

\footnotetext{
${ }^{24}$ IRS Form 990 is available at http://www.irs.gov/uac/Form-990,-Return-of-Organization-Exempt-From-Income-Tax-.

${ }^{25}$ Instructions for Schedule D (Form 990) are available at http://www.irs.gov/uac/Form-990,-Return-of-OrganizationExempt-From-Income-Tax-.

${ }^{26}$ See General Explanations of the Administration's Fiscal Year 2013 Revenue Proposals, Treas. Dep't 140 (February 2012), available at http://www.treasury.gov/resource-center/tax-policy/Documents/General-ExplanationsFY2013.pdf.
} 


\section{IRS General Information Letter on Swaps}

In a March 2012 Information Letter, the IRS advised that conservation easements that are subject to swaps other than in the very limited situation of a swap that meets the extinguishment and proceeds requirements of Treasury Regulation $\S 1.170 \mathrm{~A}-14(\mathrm{~g})(6)$ are not deductible. ${ }^{27} \mathrm{~A}$ "swap" is defined as the removal of some or all of the originally protected property from the terms of the original deed of conservation easement in exchange for either the protection of some other property or the payment of cash.

\section{N. IRS General Information Letter on Extinguishment}

In a September 2012 Information Letter, the IRS advised that, while state law may provide a means for extinguishing a conservation easement for state law purposes, the requirements of $\S 170(\mathrm{~h})$ and the Treasury Regulations, including Treasury Regulation $\S 1.170 \mathrm{~A}-14(\mathrm{~g})(6)$ (the judicial extinguishment and division of proceeds regulation), must nevertheless be satisfied for a contribution to be deductible for federal income tax purposes. $^{28}$

\section{O. DOJ Suit Against Façade Easement Appraiser}

In January 2013, the United States filed a complaint in District Court against an appraiser and the company he owned with his wife. ${ }^{29}$ The complaint alleged, among other things, that the appraiser had appraised more than ninety conservation easements for purposes of the deduction under $\S 170(\mathrm{~h})$ and had repeatedly and continually made material and substantive errors, distorted data, and provided misinformation and unsupported personal opinions in the appraisals to significantly inflate the value of the easements for federal deduction purposes. The complaint also alleged that the appraiser attempted to obstruct IRS enforcement efforts by claiming not to have any work files for his appraisal reports, which professional standards require that an appraiser maintain. "This sort of abuse of a high-dollar charitable contribution deduction," stated the complaint, "inspires contempt for the system of honest, voluntary income tax reporting."

In February 2013, the District Court issued an Agreed Order of Permanent Injunction that, among other things, (i) barred the appraiser (who was 70 years old and had retired) and the company from preparing any kind of appraisal report or otherwise participating in the appraisal process for any property relating to federal taxes and (ii) ordered the appraiser and the company to provide to counsel for the United States a list

\footnotetext{
${ }^{27}$ Information Letter from Karin Goldsmith Gross, Senior Technician Reviewer, IRS (March 5, 2012), available at http://www.irs.gov/pub/irs-wd/12-0017.pdf.

${ }^{28}$ Information Letter from Karin Goldsmith Gross, Senior Technician Reviewer, IRS (Sept. 18, 2012), available at http://bit.ly/1VMfimR.

${ }^{29}$ Complaint for Permanent Injunction and Other Relief, U.S. v. Ehrmann et al., Civ. No. 1:13-cv-214 (N.D. Ohio, Jan. 30, 2013).
} 
of clients for whom they prepared appraisal reports for tax purposes on or since November 1, 2009. ${ }^{30}$

\section{P. Administration's Fiscal Year 2014 Revenue Proposals}

In April 2013, the Treasury Department published General Explanations of the Administration's Fiscal Year 2014 Revenue Proposals, one of which was the same proposal to eliminate the deduction for contributions of conservation easements on golf courses that was included in the Administration's 2013 proposals. ${ }^{31} \mathrm{~A}$ second proposal called for (i) disallowing the deduction for the value of a façade easement associated with forgone upward development above a historic building and (ii) requiring that contributions of façade easements on buildings listed in the National Register comply with Internal Revenue Code rules applicable to façade easements on buildings located in a registered historic district. The Treasury Department explained, in part:

The value of [a façade] easement may be zero if it does not restrict future development more than the restrictions already imposed on the building, for example, by local zoning or historic preservation authorities. Some taxpayers, however, have taken large deductions for contributions of easements restricting the upward development of historic urban buildings even though such development was already restricted by local authorities. Because of the difficulty of determining the value of the contributed easement, it is difficult and costly for the Internal Revenue Service to challenge deductions for historic preservation easements. To prevent abuses, no deduction should be allowed for the value associated with forgone upward development above an historic building.

\section{Q. IRS Chief Counsel Advice on Conservation Easement Valuation}

In August 2012, the IRS Office of Chief Counsel published helpful guidance on valuing conservation easements in accordance with some of the more technical requirements of Treasury Regulation $\S 1.170 \mathrm{~A}-14(\mathrm{~h})(3)(\mathrm{i}) .{ }^{32}$ The Chief Counsel Advice specifically addresses the "contiguous parcel" and "enhancement" rules, and provides twelve examples illustrating the application of those rules.

\footnotetext{
${ }^{30}$ Agreed Order of Permanent Injunction, U.S. v. Ehrmann, Civ. No. 1:13-cv-00214-DAP (N.D. Ohio Feb. 12, 2013) (the appraiser and company agreed to the settlement without admitting any wrongdoing). See also Ohio Federal Court Bars Appraiser of Historic-Preservation Easements, Department of Justice Press Release (Feb. 13, 2013), available at http://www.justice.gov/opa/pr/2013/February/13-tax-192.html.

${ }^{31}$ See General Explanations of the Administration's Fiscal Year 2014 Revenue Proposals, Treas. Dep't 161-162 (April 2013), available at http://www.treasury.gov/resource-center/tax-policy/Documents/General-ExplanationsFY2014.pdf.

32 IRS Chief Counsel Advice 201334039 (released Aug. 23, 2012), available at http://www.irs.gov/pub/irswd/1334039.pdf. See also IRS on Conservation Easement Valuation, at

http://lawprofessors.typepad.com/nonprofit/2014/09/irs-on-conservation-easement-appraisals.html.
} 


\section{R. Administration's Fiscal Year 2015 Revenue Proposals}

In March 2014, the Treasury Department published General Explanations of the Administration's Fiscal Year 2015 Revenue Proposals. ${ }^{33}$ In addition to eliminating the deduction for contributions of conservation easements on golf courses and restricting the deduction and harmonizing the rules for contributions of façade easements (both of which were part of the Administration's 2014 proposals), the Administration's 2015 proposals also called for making permanent the enhanced incentives for conservation easement donations that had expired on December 31, 2013.

\section{S. IRS Bars Appraisers from Valuing Easements for Five Years}

In March 2014, the IRS issued a press release announcing that its Office of Professional Responsibility (OPR) had entered into a settlement agreement with a group of appraisers from the same firm accused of aiding in the understatement of federal tax liabilities by overvaluing facade easements for charitable donation purposes. ${ }^{34}$ To value the facade easements, the appraisers had simply multiplied the "before" value of the property by a fixed percentage, generally $15 \%$.

Under the settlement agreement, the appraisers admitted to violating relevant sections of Circular 230. According to Karen L. Hawkins, Director of OPR:

Appraisers need to understand that they are subject to Circular 230, and must exercise due diligence in the preparation of documents relating to federal tax matters. Taxpayers expect advice rendered with competence and diligence that goes beyond the mere mechanical application of a rule of thumb based on conjecture and unsupported conclusions.

The appraisers agreed to a five-year suspension of valuing facade easements and undertaking any appraisal services that could subject them to penalties under the Internal Revenue Code. The appraisers also agreed to abide by all applicable provisions of Circular 230.

\footnotetext{
${ }^{33}$ See General Explanations of the Administration's Fiscal Year 2015 Revenue Proposals, Treas. Dep't $193-196$ (March 2014), available at http://www.treasury.gov/resource-center/tax-policy/Documents/General-ExplanationsFY2015.pdf.

${ }^{34}$ IRS, IRS Bars Appraisers from Valuing Facade Easements for Federal Tax Purposes for Five Years, IR-2014-31 (March 19, 2014), available at http://www.irs.gov/uac/Newsroom/IRS-Bars-Appraisers-from-Valuing-Facade-Easements-forFederal-Tax-Purposes-for-Five-Years.
} 


\section{T. Administration's Fiscal Year 2016 Revenue Proposals}

In February 2015, the Treasury Department published General Explanations of the Administration's Fiscal Year 2016 Revenue Proposals. ${ }^{35}$ As in the Administration's 2014 and 2015 proposals, the 2016 proposals called for (i) eliminating the deduction for contributions of conservation easements on golf courses and (ii) restricting the deduction and harmonizing the rules for contributions of the two types of façade easements. The Administration's 2016 proposals also included two new conservation easement-related proposals.

First, the Administration proposed to make permanent the enhanced incentives for conservation easement donations that expired on December 31, 2014. However, because of concerns regarding abuse, the Administration also proposed a number of reforms to $\S 170(\mathrm{~h})$, including:

- requiring all conservation easements to further a clearly delineated Federal or authorized state or tribal governmental policy and yield a significant public benefit;

- requiring donors to provide detailed information about the conservation purposes and public benefit of contributed easements;

- requiring donees to meet minimum standards, attest to the accuracy of donor representations to the IRS, and electronically report information about donated easements, and

- subjecting donees to loss of "eligible donee" status and donees and their managers to penalties for overvalued easements or easements that do not further eligible conservation purposes.

The Administration also proposed to pilot a new tax credit for conservation easement donations "as an alternative" to the $\S 170(\mathrm{~h})$ deduction. A Federal interagency board would allocate $\$ 100$ million of credits to "expert" donees that would then allocate the credits to donors. The proposal called for a report to Congress from the Secretaries of the Treasury, Agriculture, and the Interior on the relative merits of the credit versus the deduction.

\section{U. Enhanced Incentives Made Permanent Without Modifications}

On December 18, 2015, President Obama signed into law the Protecting Americans from Tax Hikes Act of 2015 (the PATH Act). ${ }^{36}$ Before the PATH Act, as a general rule, a property owner could claim the deduction generated by an easement donation to the

\footnotetext{
${ }^{35}$ See General Explanations of the Administration's Fiscal Year 2016 Revenue Proposals, Treas. Dep't 188-192 (Feb. 2015), available at http://www.treasury.gov/resource-center/tax-policy/Documents/General-ExplanationsFY2016.pdf.

${ }^{36}$ See Technical Explanation of the Protecting Americans From Tax Hikes Act of 2015, prepared by the JCT, JCX-144-15 (Dec. 17, 2015), available at https://www.jct.gov/publications.html?func=startdown\&id=4861.
} 
extent of $30 \%$ of the property owner's adjusted gross income (AGI) in each of the year of the donation and the following five years. Based on changes made in 2006, which were temporary and repeatedly extended temporarily, easement donors were permitted to claim the resulting deduction to the extent of $50 \%$ of the donor's AGI in the year of the donation and the following 15 years, or, for qualifying farmer and rancher donations, $100 \%$ of the donor's AGI for the 16-year period. The PATH Act made these favorable rules for easement donations permanent. In addition, beginning in 2016, the Act allows an Alaska Native Corporation donating a conservation easement with respect to certain lands to claim the resulting deduction to the extent of $100 \%$ of taxable income in the year of the donation and the following 15 years. Accordingly, farmers, ranchers, and Alaska Native Corporations that make qualifying easement donations could potentially avoid paying any income tax for up to 16 years.

The PATH Act made the enhanced incentives permanent without implementing any reforms proposed by the Treasury or others to curb abuses. ${ }^{37}$

\section{Administration's Fiscal Year 2017 Revenue Proposals}

In February 2016, the Treasury Department published General Explanations of the Administration's Fiscal Year 2017 Revenue Proposals. ${ }^{38}$ The 2017 proposals repeated the 2016 reform proposals regarding conservation and façade easements, and also made clear that the Treasury is proposing to replace the $\S 170(\mathrm{~h})$ deduction with a tax credit program. $^{39}$

\section{W. Broad IRS Summons Served on Appraiser and CPA}

In April 2016, a U.S. District Judge for the Northern District of Georgia granted the IRS's petition to enforce a summons served on an appraiser. ${ }^{40}$ In the summons, the IRS requested: (i) all of the appraiser's marketing documents for the valuation of conservation easements; (ii) all documents reflecting the customers for whom the appraiser prepared or approved conservation or historic easement appraisals during the

\footnotetext{
${ }^{37}$ See, e.g., Roger Colinvaux, Conservation Easements: Design Flaws, Enforcement Challenges, and Reform, 2013 UTAH LAW Review 755, available at http://bit.ly/29K2Ual; Wendy C. Gerzog, Alms to the Rich: The Façade Easement Deduction, 34 VA. TAX REV. 229 (2014), available at http://papers.ssrn.com/sol3/papers.cfm?abstract_id=2447975; Daniel Halperin, Incentives for Conservation Easements: The Charitable Deduction or a Better Way, 74 LAW \& CONTEMP. PROBS. 29 (2011), available at http://bit.ly/29wYOS3; Nancy A. McLaughlin, Conservation Easements and the Valuation Conundrum, 19 Fla. TAX REv. 225 (2016), available at http://bit.ly/29pyA0y; Nancy A. McLaughlin, Extinguishing and Amending Tax-Deductible Conservation Easements: Protecting the Federal Investment After Carpenter, Simmons, and Kaufman, 13 Fla. TaX Rev. 217 (2012), available at http://bit.ly/29x01Zq; Jeff Pidot, ReInVEnting Conservation EASEMENTS: A CRITICAL EXAMINATION ANd IDEAS FOR RefORM (LINCOLn INSTITUTE OF LAND Policy 2005), http://bit.ly/29FWoPx.

38 See General Explanations of the Administration's Fiscal Year 2017 Revenue Proposals, available at https://www.treasury.gov/resource-center/tax-policy/Documents/General-Explanations-FY2017.pdf.

${ }^{39}$ See id. At 213-216 ("If the [tax credit pilot program] is successful, replacement of the deduction with a conservation easement credit of $\$ 475$ million annually, indexed for inflation, is estimated to be budget neutral").

${ }^{40}$ U.S. v. Clower, 2016 WL 3144048 (N.D. Ga. Apr. 29, 2016), adopting Judge's Report and Recommendation in U.S. v. Clower, 2016 WL 3129451 (N.D. Ga. March 22, 2016).
} 
period beginning January 1, 2010, through the present, (iii) all appraisal work files for such appraisals; (iv) copies of all 8283 Forms that were signed, reviewed, approved, or executed by the appraiser; and (v) all correspondence, including e-mails, related to conservation or historic easement appraisals noted in item (ii). The District Judge found that the summons had a legitimate purpose (to determine whether the appraiser had improperly appraised conservation easements), the summons was not overbroad, and the IRS was not acting in bad faith.

In June 2016, a U.S. District Judge for the Northern District of Georgia granted the IRS'S petition to enforce a summons served on a certified public accountant. ${ }^{41}$ The CPA had prepared or filed approximately eight to ten conservation-easement partnership federal tax returns for each of the years 2010, 2011, and 2012; participated as an investor in at least one conservation-easement partnership; and formed at least one conservationeasement partnership, serving as the tax-matters partner. Among other things, the IRS was seeking client files, tax returns, and supporting documentation for federal tax returns prepared by the CPA for tax years 2010-2012 that were either conservationeasement partnership returns or federal income-tax returns where the client claimed a charitable deduction arising from a conservation easement. Quoting the Eleventh Circuit, which was quoting the Supreme Court, the judge explained, in part, that:

"[T]he Government depends upon the good faith and integrity of each potential taxpayer to disclose honestly all information relevant to tax liability.... The purpose of ... [a summons] is not to accuse, but to inquire. Although such investigations unquestionably involve some invasion of privacy, they are essential to our self-reporting system, and the alternatives could well involve far less agreeable invasions of house, business, and records."

\section{Treasury's 2016-2017 Priority Guidance Plan}

The Treasury's 2016-2017 Priority Guidance Plan contains 281 projects that are priorities for allocation of the resources of its offices from July 2016 through June $2017 .^{42}$ The plan represents projects the Treasury intends to work on actively during the plan year and does not place any deadline on completion of projects. One of the listed projects is "[g]uidance under $\$ 170$ regarding charitable contributions of conservation easements."

\footnotetext{
${ }^{41}$ U.S. v. Greenberger, 2016 WL 3912060 (N.D. Ga. June 21, 2016), adopting Judge's Report and Recommendation in U.S. v. Greenberger, 2016 WL 391206 (N.D. Ga. Jan. 11, 2016).

42 Department of the Treasury, 2016-2017 Priority Guidance Plan, available at https://www.irs.gov/pub/irs-utl/20162017_pgp_initial.pdf.
} 


\section{Y. Deduction Statistics}

The following chart indicates estimates of the number of easement donations reported on individual income tax returns in the year designated and the average donation amount per return. ${ }^{43}$

$\begin{array}{ccc}\frac{\text { Year }}{2003} & \text { Number Donations }^{44} & \text { Avg. Donation Amount Per Return } \\ 2004 & 2,407(\mathrm{~L} \& \mathrm{~F}) & \$ 684,733 \\ 2005 & 3,365(\mathrm{~L} \& \mathrm{~F}) & \$ 487,785 \\ 2005 & 2,307(\mathrm{~L}) & \$ 830,481 \\ 2006 & 1,132(\mathrm{~F}) & \$ 299,080 \\ 2006 & 3,529(\mathrm{~L}) & \$ 437,895 \\ 2007 & 1,145(\mathrm{~F}) & \$ 231,572 \\ 2007 & 2,405(\mathrm{~L}) & \$ 875,891 \\ 2008 & 242(\mathrm{~F}) & \$ 974,779 \\ 2008 & 3,158(\mathrm{~L}) & \$ 380,541 \\ 2009 & 1,396(\mathrm{~F}) & \$ 32,462 \\ 2009 & 2,102(\mathrm{~L}) & \$ 483,522 \\ 2010 & 103(\mathrm{~F}) & \$ 477,225 \\ 2011 & 3,241(\mathrm{~L} \& \mathrm{~F}) & \$ 261,027 \\ 2012 & 2,202(\mathrm{~L} \& \mathrm{~F}) & \$ 383,179 \\ & 1,238(\mathrm{~L} \& \mathrm{~F}) & \$ 872,250\end{array}$

\section{Z. Case Law}

Appendix $C$ lists the cases involving challenges to deductions claimed with respect to easement donations as of October 4, 2016. The cases are referred to in this outline by case name and numerical designation only (e.g., Belk III, Carpenter I, Palmer Ranch II). Appendix $\mathrm{H}$ includes blog posts discussing the more recent cases and other select developments. The blog posts include live links to the cases and other source materials.

\footnotetext{
${ }^{43}$ See Pearson Liddell \& Janette Wilson, Individual Noncash Contributions, 2012, Stat. of Income Bull., Spring 2015, at 1; Pearson Liddell \& Janette Wilson, Individual Noncash Contributions, 2011, Stat. of Income Bull., Spring 2014, at 111; Pearson Liddell \& Janette Wilson, Individual Noncash Contributions, 2010, Stat. of Income Bull., Winter 2013, at 64; Pearson Liddell \& Janette Wilson, Individual Noncash Contributions, 2009, Stat. of Income Bull., Spring 2012, at 63; Pearson Liddell \& Janette Wilson, Individual Noncash Contributions, 2008, Stat. of Income Bull., Winter 2011, at 77; Pearson Liddell \& Janette Wilson, Individual Noncash Contributions, 2007, Stat. of Income Bull., Spring 2010, at 53; Pearson Liddell \& Janette Wilson, Individual Noncash Contributions, 2006, Stat. of Income Bull., Summer 2009, at 68; Janette Wilson, Individual Noncash Contributions, 2005, Stat. of Income Bull., Spring 2008, at 69; Janette Wilson \& Michael Strudler, Individual Noncash Contributions, 2004, Stat. of Income Bull., Spring 2007, at 78; Janette Wilson \& Michael Strudler, Individual Noncash Contributions, 2003, Stat. of Income Bull., Spring 2008, at 69 (2003 was the first year detailed information was collected from individual income tax returns with noncash charitable contributions greater than $\$ 500$ and the statistics are based on a sample of individual income tax returns).

44 " $\mathrm{L}$ " refers to conservation easements encumbering land and " $F$ " refers to façade easements. In some years the statistics for the two types of easements were combined in the Statistics of Income Bulletin.
} 


\section{Filing a Tax Return Package to Minimize Risk of Audit}

- Correctly Drafted Conservation Easement

- IRS Form 8283 \& Supplemental Statement

- Qualified Appraisal

- Contemporaneous Written Acknowledgment

- Compelling and Timely Baseline Documentation

- Correct and Timely Lender Agreement (if applicable)

\section{A. Correctly Drafted Conservation Easement Deed}

1. Copy of Final Conservation Easement Deed. A copy of the correctly drafted and recorded conservation easement deed should be either (i) filed with IRS Form 8283, section B (the appraisal summary) or (ii) if the easement is valued at more than $\$ 500,000$, included in the qualified appraisal filed with IRS Form 8283.

a. Best practice is to either (i) file the date stamped copy of the recorded easement deed with the Form 8283 or (ii) have the appraiser include the date stamped copy of the recorded easement deed in the appraisal. It is imperative that the appraiser values the restrictions as they appear in the final recorded easement deed rather than in an earlier draft.

b. As noted in the discussion of IRS Form 8283 in Part II.B below, the IRS has informally suggested that a copy of the qualified appraisal be included in the package filed with the income tax return on which a deduction for the easement donation is first claimed even if the appraised value of the easement is $\$ 500,000$ or less.

Façade easements on buildings in registered historic districts are subject to special rules. The taxpayer must include with the taxpayer's return for the year of the contribution, in addition to the Form 8283: (i) a qualified appraisal, (ii) photos of the entire exterior of the building, and (iii) a description of all restrictions on the development of the building. ${ }^{45} \mathrm{~A}$ date stamped copy of the recorded easement deed should be included with these items. If the deduction claimed is more than $\$ 10,000$, it will be allowed only if the taxpayer also includes a $\$ 500$ filing fee. ${ }^{46}$

2. Extensive Recitals. The conservation easement deed should include extensive recitals clearly indicating the conservation or historic values of the property worthy of protection.

\footnotetext{
${ }^{45}$ See IRC $\S 170(\mathrm{~h})(4)(\mathrm{B})(\mathrm{iii})$.

${ }^{46}$ See IRC § 170(f)(13); IRS Form 8283-V, available at http://www.irs.gov/pub/irs-pdf/f8283v.pdf.
} 
3. "Exclusively for Conservation Purposes." To be eligible for a deduction, the donation of a conservation easement must, among other things, be a contribution made "exclusively" for one of more of the four "conservation purposes" enumerated in $\S 170(\mathrm{~h}) .{ }^{47}$ The contribution will not be treated as made exclusively for conservation purposes unless the conservation purpose is "protected in perpetuity." ${ }^{48}$ Satisfying the "protected in perpetuity" requirement requires satisfying all of the following requirements: ${ }^{49}$

a. the eligible donee requirement, ${ }^{50}$

b. the restriction on transfer requirement, ${ }^{51}$

c. the no inconsistent uses requirement, ${ }^{52}$

d. the general enforceable in perpetuity requirement, ${ }^{53}$

e. the mortgage subordination requirement, ${ }^{54}$

$\mathrm{f}$. the mineral extraction restrictions requirement, ${ }^{55}$

g. the baseline documentation, donee notice, donee access, and donee enforcement requirements, ${ }^{56}$ and

h. the extinguishment and division of proceeds requirements. ${ }^{57}$

Analysis by the IRS and the courts of satisfaction of the "exclusively for conservation purposes" requirement generally has not been systematic, making the cases somewhat difficult to categorize. Areas of focus have included whether the purpose is "protected in perpetuity" despite reserved rights or inconsistent uses, satisfaction of the conservation purposes test generally, whether the extinguishment and division of proceeds requirements were satisfied, and whether the mortgage subordination requirement was satisfied.

\footnotetext{
${ }^{47}$ IRC § 170(h)(4); Treas. Reg. § 1.170A-14(d). The four conservation purposes are protection of habitat, protection of open space, historic preservation, and preservation of land for outdoor recreation by or education of the general public. Id. § $170(\mathrm{~h})(4)(\mathrm{A})$.

${ }^{48}$ IRC $\S 170(h)(1)(C),(5)(A)$.

${ }^{49}$ See IRC $\S 170(\mathrm{~h})(5)(\mathrm{B})$ (addressing surface mining); Treas. Reg. § 1.170A-14(e)(1) ("To meet the requirements of this section, a donation must be exclusively for conservation purposes. See paragraphs (c)(1) and (g)(1) through (g)(6)(ii) of this section."). In addition, in explaining the "protected in perpetuity" requirement, the Senate Finance Committee provided instructions that were incorporated into the regulations as the restriction on transfer and no inconsistent use requirements of regulation sections 1.170A-14(c)(2) and -14(e)(2). See S. Rep. No. 96-1007, 1980-2 C.B.

${ }^{50}$ Treas. Reg. § 1.170A-14(c)(1).

${ }^{51}$ Id. $\S 1.170 \mathrm{~A}-14(\mathrm{c})(2)$.

52 Id. $\S 1.170 \mathrm{~A}-14(\mathrm{e})(2),(3)$.

53 Id. $\S 1.170 \mathrm{~A}-14(\mathrm{~g})(1)$.

${ }^{54}$ Id. $\S 1.170 \mathrm{~A}-14(\mathrm{~g})(2)$ (applicable only if the property is subject to a mortgage at the time of the donation).

${ }^{55}$ IRC § 170(h)(5)(B); Treas. Reg. § 1.170A-14(g)(4).

${ }^{56}$ Id. $\S 1.170 \mathrm{~A}-14(\mathrm{~g})(5)(\mathrm{i})$ and (ii). These requirements are applicable only if the "donor reserves rights the exercise of which may impair the conservation interests associated with the property." However, that will almost always be the case. Moreover, it is common practice and recommended that these requirements be satisfied with regard to every conservation easement donation because they help to ensure the holder will have the information as well as the notice, access, and enforcement rights needed to properly enforce the easement.

57 Treas. Reg. § 1.170A-14(g)(6)(i) and (ii).
} 
4. Reserved Rights. In two cases, Glass and Butler, the IRS argued unsuccessfully that, at full exercise of all reserved rights, the conservation purposes of the easements would not be protected in perpetuity.

a. Glass. In Glass, the 6th Circuit affirmed the Tax Court's holding that two conservation easements protecting small portions of a ten-acre parcel located along the shoreline of Lake Michigan satisfied the "exclusively" for habitat protection "conservation purposes" requirement. The IRS argued, among other things, that the easements failed to satisfy this requirement because (i) the protected properties were too small, (ii) the taxpayers reserved too many rights in the easements, and (iii) there were no limits on building on neighboring properties. The 6th Circuit rejected those arguments, finding that (i) neither $\S 170(\mathrm{~h})$ nor the Treasury Regulations require that the subject property be a minimum size, ${ }^{58}$ (ii) although the easements reserved various use rights to the taxpayers, both also contained an overarching restriction prohibiting "[a]ny activity on or use of the Property that is inconsistent with the purpose of this Conservation Easement," and provided that the easement "shall be liberally construed in favor of the purpose of [the easement, the land trust holder, and the state conservation easement enabling statute]," and (iii) neither $\S 170(\mathrm{~h})$ nor the Treasury Regulations require consideration of neighboring property owners' building rights when assessing the deductibility of a conservation easement. The taxpayers in Glass also provided credible testimony at trial indicating that exercise of the reserved rights would not be inconsistent with the habitat protection conservation purposes of the conservation easements, while the IRS failed to provide any evidence to the contrary. See also Part II.A.5.b below.

The 6th Circuit concluded that the habitat protection conservation purpose of the easements was "protected in perpetuity" because the requirements of Treasury Regulation 1.170A-14(c)(1), -14(e)(2) and (3), and $-14 g(1)$ through (6) were satisfied.

b. Butler. In Butler, the IRS asserted that the rights retained by the landowners in the conservation easement deeds meant that the habitat and open space protection conservation purposes of the easements were not "protected in perpetuity." The Tax Court disagreed, finding that the habitat protection conservation purpose test would still be satisfied even if the properties were developed to the fullest extent permitted by the

${ }^{58}$ For a critique of the 6th Circuit's holding on this point, see Jonathan M. Burke, A Critical Analysis of Glass $v$. Commissioner: Why Size Should Matter for Conservation Easements, 61 TAX LAWYER 599 (2008). 
easement deeds. ${ }^{59}$ However, the holding in Butler should not be viewed as a green light for retaining extensive development and use rights in a conservation easement deed for a number of reasons.

- The burden of proof regarding satisfaction of the conservation purposes test, which normally falls on the taxpayer, had shifted to the IRS.

- The parties disagreed about whether the conservation easement deeds restricted the location of the building sites. The donors argued that the deeds incorporated the baseline documentation by reference, and the baseline included a map stipulating the placement of the building sites in locations consistent with the preservation of the conservation purposes. The court found that, under Georgia law, reference in the recorded deeds to the baseline effectively made the baseline (including the map) part of the recorded deeds, and the restrictions on the location of the lots in the map were therefore binding.

- The donors offered some (albeit "sparse") evidence in the form of testimony of environmental consultants to support their contention that the reserved rights were not inconsistent with the conservation purposes of the easements and, as in Glass, the IRS failed to introduce any evidence to the contrary.

- After Butler was decided, the IRS informally indicated that in future cases it intends to hire its own environmental experts to testify as to whether the conservation purpose of an easement would be preserved upon full exercise of all reserved rights. As discussed in Part II.A.5.e. below, the IRS hired its own environmental expert in Atkinson and, as a result, was able to establish that the easements at issue did not satisfy habitat protection conservation purpose test due, in part, to the reserved rights in the deeds.

c. Overarching Restriction. To prevent uses inconsistent with the conservation purposes of the donation, a conservation easement should (1) specifically reserve to the grantor (and the grantor's successors) only those rights that, even if fully exercised, would allow the conservation purpose of the easement to be accomplished, (2) specifically prohibit activities that are inconsistent with the conservation purpose of the

${ }^{59}$ Because the court found that the easements satisfied the habitat protection conservation purposes test it did not address the open space conservation purposes test. 
easement (such as subdivision, mining, and industrial uses), and (3) because it is impossible at the time of conveyance to specify in the deed every conceivable variation of use, activity, or practice that in the future might have an adverse impact on the conservation purpose of the easement, include an overarching restriction prohibiting any activities that are inconsistent with the conservation purpose of the easement or the perpetual protection of the property's conservation values. The overarching restriction is necessary to prevent the present or a future landowner from claiming that she has the right to do anything not specifically prohibited by the easement even if it would be inconsistent with the purpose of the easement or continued protection of the property's conservation values. $^{60}$

d. Liberal Construction Provision. A conservation easement should also include a clause stating that the parties to the easement (and their successors) affirmatively agree and intend that, notwithstanding any general rule of construction to the contrary, the easement shall be liberally construed in favor of permanently protecting the property's conservation values and carrying out the conservation purposes of the easement. ${ }^{61}$ In the absence of such a provision, there is a danger that ambiguous terms in the easement will be construed in favor of free use of land and that the conservation purposes of the easement may not be deemed "protected in perpetuity" as required by $\S 170(\mathrm{~h}){ }^{62}$

Some state conservation easement enabling statutes mandate that conservation easements be liberally construed in favor of effecting their conservation purposes. ${ }^{63}$ However, given that statutes are subject to

${ }^{60}$ See Glass; Priv. Ltr. Rul. 200836014.

${ }^{61}$ See, e.g., Byers \& Ponte, The Conservation Easement Handbook 376, 466-67 (2d ed. 2005).

${ }^{62}$ See Wetlands America Trust v. White Cloud Nine Ventures, _ S.E.2d _ (Va. 2016), 2016 WL 550339 (holding that the common law rule of construction requiring land use restrictions to be interpreted in favor of free use of land applied to the conservation easement at issue and the enabling statutes in Virginia do not abrogate that rule of construction). There was a strong dissent:

Contrary to the majority's conclusion, the common law principle of strict construction in favor of free use of land no longer applies to conservation easements. The strict construction principle was applied under the common law because easements in gross, including negative easements in gross, were disfavored as a matter of public policy. Today, and for at least the last four decades, Virginia public policy strongly favors the conservation of land and open spaces.... The oft-stated policy of the Commonwealth in favor of conservation easements such as the type at issue here could not be a clearer rejection of the common law strict construction principle.

See id. See also Nancy A. McLaughlin, Interpreting Conservation Easements, 29 PROB. \& Prop. 30 (2015) (explaining why conservation easements should be interpreted in favor of carrying out their public-benefiting conservation purposes rather than in favor of free use of land), available at http://bit.ly/1KSyi2U.

${ }^{63}$ See 32 PA. CONS. STAT. § 5055(c)(2) ("Any general rule of construction to the contrary notwithstanding, conservation or preservation easements shall be liberally construed in favor of the grants contained therein to effect the purposes of those easements and the policy and purpose of this act"); W. VA. CODE § 20-12-5(b) ("Notwithstanding provision of law to the contrary, conservation and preservation easements shall be liberally construed in favor of the grants contained therein to effect the purposes of those easements and the policy and purpose of this article"). 
change at any time, every conservation easement deed should nonetheless include a liberal-construction-in-favor-of-conservationpurposes provision.

e. Reserved Development Rights. For a discussion of Treasury Regulation requirements regarding permissible and impermissible reserved development rights, see Part III.F. below.

5. The Conservation Purposes Test. Satisfaction of the conservation purposes test was an issue in Turner, Glass, Herman I, RP Golf, LLC, Atkinson, and Carroll.

a. Turner. In Turner, the Tax Court held that the IRS properly disallowed deductions claimed with respect to the donation of a conservation easement because the donation did not satisfy either the open space or historic preservation conservation purposes tests. Turner involved a purported donation to Fairfax County, Virginia, of a conservation easement encumbering a 29.3-acre parcel located in a historic overlay district. ${ }^{64}$ The subject property is in the general vicinity of Mount Vernon, President George Washington's 500-acre residential estate; adjacent to President Washington's Grist Mill; and in close proximity to the Woodlawn Plantation, which was built in 1805 on land owned by President Washington. In obtaining an appraisal of the easement, the donor (an attorney whose practice concentrated on real estate transactions) represented that 60 residences could be built on the 29.3acre parcel and that the easement reduced the number of permitted residences to 30 . In reality, however, zoning regulations already limited development to 30 residences because slightly more than half of the parcel (15.04 acres) was situated within a designated 100-year floodplain. ${ }^{65}$

The Tax Court held that the easement did not satisfy the open space conservation purpose test because it did not limit the size of the residences that could be built on the 15 acres (either in square footage or height) and did not contain any provisions to protect the views from the nearby historic sites. The easement also did not satisfy the historic preservation conservation purpose test because it did not preserve a historic structure or historically important land area. The court explained:

Here there has been no preservation of open space. Nor [has the donor] preserved anything that is historically unique about the

\footnotetext{
${ }^{64}$ The donation is referred to as "purported" because Fairfax County did not sign or acknowledge the conservation easement deed or sign the Form 8283.

${ }^{65}$ Although the donor could have attempted to obtain approval to rezone the parcel, the court noted that obtaining such approval would have been time-consuming and costly and success was not guaranteed.
} 
property or the surrounding historical areas. [The donor] simply developed the property to its maximum yield within the property's zoning classification. ${ }^{66}$

b. Glass. In Glass, the 6th Circuit affirmed the Tax Court's holding that two conservation easements protecting small portions of a ten-acre parcel located along the shoreline of Lake Michigan satisfied the habitat protection "conservation purposes" test. The IRS argued that the easements failed to satisfy this test because, among other things, ${ }^{67}$ threatened species had not actually been sighted living on the properties. The 6th Circuit rejected that argument, finding that (i) the habitat protection conservation purposes test can be satisfied if the easement protects property that is potential habitat for rare, threatened, or endangered species, and (ii) one of the taxpayers and the executive director of the land trust holder credibly testified that the property was a "famous roosting spot" for bald eagles and there were threatened plant species on the properties.

c. Herman I. In Herman I the Tax Court sustained the IRS's disallowance of a \$21.8 million deduction for the conveyance of a facade easement to the National Architectural Trust. The easement encumbered 10,000 unspecified square feet of the approximately 22,000 square feet of unused development rights (UDRs) above a certified historic structure (or 45 percent of the UDRs). ${ }^{68}$ The easement did not, however, prevent alteration or demolition of the structure or prohibit the building of six stories over any half (front, back, or side) of the structure. Accordingly, the court found that the easement did not protect either the structure or the historic significance of the underlying land and, thus, did not satisfy the historic preservation conservation purposes test. Section 170 (h) has since been amended to expressly require that, to be deductible, a façade easement with respect to a building in a registered historic district must preserve the entire exterior of the building, including the space above the building, the sides, the rear, and the front of the building. ${ }^{69}$

\footnotetext{
${ }^{66}$ See also Joe Stephens, IRS Gets 'First Big Win' in Push to Stem Abuse of Conservation Tool, WASH. Post A01 (June 4, 2006) (describing the transaction as a $\$ 3.1$ million donation that promised not to overdevelop scenic land once owned by George Washington and located down the road from Mount Vernon, but developers clear-cut acres of trees on the property and erected 29 sprawling homes that preservationists today deride as 'McMansions.'").

${ }^{67}$ See also discussion of reserved rights in Part II.A.4.

${ }^{68}$ The certified historic structure was an eleven-story apartment building located on Fifth Avenue in New York City that had been designed by the late Henry Otis Chapman in 1923 in the neo-Italianate Renaissance style of architecture.

${ }^{69}$ See IRC $\S 170(\mathrm{~h})(4)(\mathrm{B})(\mathrm{i})$. See also Technical Explanation Of H.R. 4, The "Pension Protection Act Of 2006," prepared by the JCT, JCX-38-06 at 294-95 (August 3, 2006), available at https://www.jct.gov/publications.html?func=select\&id=20.
} 
d. RP Golf, LLC. In RP Golf, LLC, the IRS asserted that the conservation easement donation at issue was not made "exclusively for conservation purposes," in part because the Missouri conservation policy the taxpayer referenced in the easement deed was limited to certain areas of the state and there was no evidence that the subject property was located in such an area on the date of the donation. The taxpayer was forced to concede that the easement was not made pursuant to a "clearly delineated governmental conservation policy," and the Tax Court granted the IRS's motion for summary judgment on that issue. ${ }^{70}$

e. Atkinson. In Atkinson, the Tax Court denied $\$ 7.88$ million of deductions claimed with regard to the conveyance of conservation easements encumbering land on and adjacent to golf courses located in a gated residential community west of Southport, North Carolina. The court determined that the easements, which were conveyed to the North American Land Trust (NALT), did not satisfy either the habitat or open space protection conservation purposes tests. The properties subject to the easements consisted of noncontiguous tracts (i.e., fairways, greens, teeing grounds, ranges, roughs, ponds, and wetland areas); residential lots bordered most of the tracts; and a concrete golf cart path winded its way through the tracts. The taxpayers argued that each of the subject properties had independent conservation significance and contributed to the ecological viability of surrounding conservation areas. The IRS focused on the operation of the golf courses and argued that the rights retained in the easements negated any purported conservation purpose. Although the taxpayer generally has the burden of proving that an asserted deficiency is incorrect, the burden of proof regarding satisfaction of the habitat (but not open space) protection conservation purpose test shifted to the IRS under IRC $\S 7491$.

Unlike in Glass and Butler, in Atkinson both the taxpayers and the IRS presented expert environmental testimony to establish their respective positions regarding the habitat protection conservation purposes test. In holding that the conservation easements did not satisfy this test, the Tax Court noted, among other things, that the most significant ecological features on the subject properties - the longleaf pine "remnants" -were not maintained in a relatively natural state worthy of conservation and were not protected in any event because the easements permitted cutting and removal of the trees; very few of the ponds had a natural edge and the few edges that existed were regularly sprayed with

\footnotetext{
${ }^{70}$ The court found that material facts regarding the easement's preservation of a natural habitat continued to be in dispute and thus denied the IRS's motion for summary judgment on that issue. The court ultimately did not rule on that issue because it sustained the IRS's disallowance of the deduction on the ground that the taxpayer failed to obtain mortgage subordination agreements at the time of the easement's donation. See Part II.F.2 below.
} 
pesticides; there were no natural fruits and seeds for foraging on the properties; the properties provided no cover for animals; and animal migration was deterred by the residential development surrounding each of the noncontiguous tracts, the level of human activity, and the frequent watering. In addition, the only birds the IRS's environmental expert observed on one of the properties were geese, which the community attempted to "control" (i.e., eliminate) using a border collie. The court also found that the use of pesticides and other chemicals in the operation of the golf course injured the ecosystems on the subject properties and, thus, violated the "no inconsistent use" requirement of Treasury Regulation $\S 1.170 \mathrm{~A}-14(\mathrm{e})(2)$. The court concluded that wildlife and plants were not "most likely" to be found and did not "normally live" on the properties subject to the easements, but declined to decide whether operating a golf course is inherently inconsistent with the conservation purpose of protecting relatively natural habitat.

With regard to the open space conservation purposes test, the Tax Court noted that the taxpayers did not mention or provide any analysis of governmental conservation policies in their briefs, and the court deemed that argument abandoned. The taxpayers also failed to establish that preservation of the subject properties was for the scenic enjoyment of the general public. Since the golf courses were in a guarded gated community and ringed by houses, the court found that the general public did not have visual access to the properties. The taxpayers argued that the general public had visual access because most of the population of the Town of St. James lived within the gated community. The court, however, did not deem the population of one town to constitute "the general public" and dismissed that argument. ${ }^{71}$

f. Carroll. In Carroll, the Tax Court sustained the IRS's disallowance of deductions claimed with regard to the donation of a conservation because the easement contained a noncompliant "proceeds" clause. ${ }^{72}$ However, the court also held that the easement satisfied the open space conservation purpose test under IRC $\S 170(\mathrm{~h})(4)(\mathrm{A})(\mathrm{iii})(\mathrm{II})$, which requires that preservation of the property be "pursuant to a clearly delineated Federal, State, or local governmental conservation policy" and "yield a significant public benefit." The easement, which encumbers a 21-acre property located in a historic district in Maryland, was granted to the Maryland Environmental Trust (MET) and the Land Preservation Trust (LPT), as joint holders. MET is a quasi-public entity that the Maryland legislature established in 1967 to conserve the environment; it is both a

\footnotetext{
${ }^{71}$ For media coverage of the case, see Richard Rubin, IRS Tees Off on Golf Courses' Green Tax Claims, WALL STREET JOURNAL (Jan. 14, 2016), at http://www.wsj.com/articles/irs-tees-off-on-golf-courses-green-tax-claims-1451959008.

${ }^{72}$ See Part II.A.13.
} 
unit of the Maryland Department of Natural Resources and governed by a board of trustees. LPT is a charitable conservation organization.

In interpreting the governmental conservation policy requirement, Treasury Regulation $\S 1.170 \mathrm{~A}-14(\mathrm{~d})(4)(\mathrm{iii})(\mathrm{B})$ provides that

Acceptance of an easement by an agency of the Federal Government or by an agency of a state or local government (or by a commission, authority, or similar body duly constituted by the state or local government and acting on behalf of the state or local government) tends to establish the requisite clearly delineated governmental policy, although such acceptance, without more, is not sufficient. The more rigorous the review process by the governmental agency, the more the acceptance of the easement tends to establish the requisite clearly delineated governmental policy. For example, in a state where the legislature has established an Environmental Trust to accept gifts to the state which meet certain conservation purposes and to submit the gifts to a review that requires the approval of the state's highest officials, acceptance of a gift by the Trust tends to establish the requisite clearly delineated governmental policy. However, if the Trust merely accepts such gifts without a review process, the requisite clearly delineated governmental policy is not established.

In finding that the easement in Carroll satisfied the open space conservation purpose test, the Tax Court explained that the thoroughness of MET's easement-review process, combined with the fact that Maryland's highest officials (the Governor, the Comptroller, and the Treasurer of Maryland) approved the easement, established that the easement preserves open space pursuant to a clearly delineated governmental conservation policy. The Tax Court also determined that preservation of the 21-acre property yielded a significant public benefit because (i) the property was in a highly desirable area under development pressure, (ii) the property was subject to a restrictive type of zoning established to foster and protect agricultural lands in certain areas, (iii) the valley in which the property was located was specifically designated in the County's Master Plan as an agricultural preservation area, and (iv) four properties adjacent to the property were encumbered by conservation easements held by MET or a state agency.

6. Extinguishment Requires Judicial Proceeding. The conservation easement deed should include provisions satisfying the restriction on transfer, 
extinguishment, division of proceeds requirements of Treasury Regulation $\S \S$ 1.170A-14(c)(2) and -14(g)(6). See Part II.A.11 below for sample provisions.

a. Carpenter I. In Carpenter I, the Tax Court held that conservation easements extinguishable by mutual agreement of the parties, even if subject to a standard such as "impossibility," fail as a matter of law to satisfy the judicial extinguishment requirements in Treasury Regulation $\S$ $1.170 \mathrm{~A}-14(\mathrm{~g})(6)(\mathrm{i})$.

(i) In support of its holding, the Tax Court explained:

Extinguishment by mutual consent of the parties does not guarantee that the conservation purpose of the donated property will continue to be protected in perpetuity. As at least one commentator has noted, the "restrictions [in a deed] are supposed to be perpetual in the first place, and the decision to terminate them should not be [made] solely by interested parties. With the decision-making process pushed into a court of law, the legal tension created by such judicial review will generally tend to create a fair result." Small, Federal Tax Law of Conservation Easements 16-4 (1986).

The court referenced this passage again in reaffirming and supplementing its opinion in Carpenter II.

(ii) With regard to federal and state law interaction, the court in Carpenter I explained:

To determine whether the conservation easement deeds comply with requirements for the ... deduction under Federal tax law, we must look to State law to determine the effect of the deeds. State law determines the nature of the property rights, and Federal law determines the appropriate tax treatment of those rights. ${ }^{73}$

(iii) The court in Carpenter I also held that the "so-remote-as-tobe- negligible" standard of Treasury Regulation $\S 1.170 \mathrm{~A}-14(\mathrm{~g})(3)$ does not modify the extinguishment requirements of Treasury Regulation $\S 1.170 \mathrm{~A}-14(\mathrm{~g})(6)(\mathrm{i})$. Accordingly, failure to comply with the extinguishment requirements cannot be cured by a

\footnotetext{
${ }^{73}$ See also Patel v. Comm'r, 138 T.C. 395 (2012) (State law determines only which sticks are in a person's bundle. ... Once property rights are determined under State law, as announced by the highest court of the State, the tax consequences are decided under Federal law).
} 
showing that the possibility of extinguishment is so remote as to be negligible.

b. Carpenter II. In Carpenter II, the Tax Court confirmed that "extinguishment by judicial proceedings is mandatory." The court specifically rejected the taxpayers' arguments that the Treasury Regulations contemplate alternatives to judicial extinguishment and the judicial proceeding requirement is "merely a safe harbor."

(i) In Carpenter II, the Tax Court also rejected the taxpayers' argument that the 1st Circuit's decision in Kaufman III was an intervening change in the law that required the court to reconsider its holding in Carpenter I. The court explained that, not only is Kaufman III not binding in the 10th Circuit (to which Carpenter would have been appealed), Kaufman III addressed legal issues different from those present in Carpenter. ${ }^{74}$ The court also noted that it does not read Kaufman III as sanctioning "putting into the hands of the parties to a conservation agreement the authority to determine when to extinguish the conservation easement so long as the donee organization gets its shares of the proceeds of a subsequent sale."

c. Mitchell II. In Mitchell II, the Tax Court similarly rejected the argument that Kaufman III was an intervening change in the law requiring it to reconsider its holding in Mitchell $I .{ }^{75}$ The court explained that, not only is Kaufman III not binding in the 10th Circuit (to which Mitchell was appealed and affirmed), Kaufman III addressed legal issues different from those present in Mitchell. ${ }^{76}$ The court reiterated that Treasury Regulation 1.170A-14(g)(6) is not "merely ... a safe harbor," and the specific provisions of Treasury Regulation $\S 1.170 \mathrm{~A}-14(\mathrm{~g})(1)$ through $(\mathrm{g})(6)$ "are mandatory and may not be ignored." The court further rejected the taxpayer's argument that the court should "draw a general rule" with respect to the in-perpetuity requirement of $\S 170(\mathrm{~h})(5)(A)$ and Treasury Regulation $\$ 1.170 \mathrm{~A}-14(\mathrm{~g})$ from the analysis in Kaufman III. The taxpayer asserted: "The regulation emphasizes perpetuating an easement's purpose as opposed to the conservation easement itself. The proceeds are protected which is the goal of the law." The Tax Court disagreed,

\footnotetext{
${ }^{74}$ Kaufman III involved interpretation of Treasury Regulation $\S 1.170 \mathrm{~A}-14(\mathrm{~g})(1)$ (the "general enforceable in perpetuity" requirement) and Treasury Regulation $\S 1.170 \mathrm{~A}-14(\mathrm{~g})(6)(\mathrm{ii})$ (the "division of proceeds" requirement). Carpenter, on the other hand, involved interpretation of Treasury Regulation $\S 1.170 \mathrm{~A}-14(\mathrm{~g})(6)(\mathrm{i})$ (the "extinguishment" requirement)).

${ }^{75}$ In Mitchell I the Tax Court sustained the IRS's disallowance of a deduction for an easement donation because the taxpayer failed to obtain a mortgage subordination agreement at the time of the gift.

${ }^{76}$ Mitchell involved interpretation of Treasury Regulation $\S 1.170 \mathrm{~A}-14(\mathrm{~g})(2)$ (the "mortgage subordination" requirement).
} 
stating: "Nowhere in Kaufman III did the Court of Appeals for the 1st Circuit state a general rule that protecting the proceeds from an extinguishment of a conservation easement would satisfy the inperpetuity requirements of section $\S 1.170 \mathrm{~A}-14(\mathrm{~g})$... generally." In other words, the court held that $\S 170(\mathrm{~h})$ requires perpetuation of the conservation easement itself, not conservation purposes generally.

d. The holdings in Carpenter I and // and Mitchell // are consistent with:

(i) IRS General Information Letter on extinguishment, ${ }^{77}$ and

(ii) the Land Trust Alliance's 2007 amendment report, which instructs:

If the conservation easement was the subject of a federal income tax deduction, then Internal Revenue Code Section $170(\mathrm{~h})$ and the Treasury Regulations Section 1.170A-14 apply.... The easement must be transferable only to another government entity or qualified charitable organization that agrees to continue to enforce the easement. The easement can only be extinguished by the holder through a judicial proceeding, upon a finding that continued use of the encumbered land for conservation purposes has become "impossible or impractical," and with the payment to the holder of a share of proceeds from a subsequent sale or development of the land to be used for similar conservation purposes. To the extent an amendment amounts to an extinguishment, the land trust must satisfy these requirements. ${ }^{78}$

e. The time for appeal of Carpenter has run. Mitchell was appealed to the 10th Circuit, which affirmed the Tax Court (see Part II.F.2 below).

\section{Swaps Are Prohibited.}

a. Belk. In Belk III, the 4th Circuit affirmed the Tax Court in holding that a conservation easement that authorizes the parties to agree to "substitutions" or "swaps" (i.e., to remove some or all of the original protected land from the easement, or unencumber that land, in exchange for the protection of similar contiguous land upon the approval of the donee land trust) is not eligible for a deduction. The 4th Circuit

\footnotetext{
${ }_{78}^{77}$ See supra note 28 and accompanying text.

${ }^{78}$ Land Tr. Alliance, Amending Conservation Easements: Evolving Practices and Legal Principles 24 (2007).
} 
explained that such an easement is not "a restriction (granted in perpetuity) on the use which may be made of the real property" as required under $\S 170(h)(2)(C)$. The 4 th Circuit agreed with the Tax Court that, to be eligible for a deduction under $\S 170(\mathrm{~h})$, a donor must grant an easement with regard to a "single, immutable" or "defined and static" parcel.

(i) The Easement. The easement at issue in Belk encumbers a 184acre semi-private golf course located in a high-end residential development near Charlotte, North Carolina. The Belks donated the easement to the Smoky Mountain National Land Trust and claimed a \$10.5 million deduction. ${ }^{79}$ The easement deed authorizes the landowner to remove land from the easement in exchange for adding an equal or greater amount of contiguous land, provided that, in the opinion of the grantee:

- the substitute property is of the same or better ecological stability,

- the substitution will have no adverse effect on the conservation purposes of the easement, and

- the fair market value of the "easement interest" placed on the substitute land will be at least equal to or greater than the fair market value of the "easement interest" extinguished with regard to the land removed from the easement.

(ii) Single Narrow Exception to Perpetuity. In affirming the Tax Court's holding that the Belks were not eligible for a deduction, the 4th Circuit explained that the "Treasury Regulations offer a single-and exceedingly narrow-exception to the requirement that a conservation easement impose a perpetual use restriction"-i.e.:

[if a] subsequent unexpected change in the conditions surrounding the property ... make[s] impossible or impractical the continued use of the property for conservation purposes, the conservation purpose can nonetheless be treated as protected in perpetuity if the restrictions are extinguished by judicial proceeding and all of the donee's proceeds ... from a subsequent sale or exchange of the property are used by the donee organization in a manner consistent with the conservation purposes of the original contribution. Treas. Reg. $\S 1.170 \mathrm{~A}-14(\mathrm{~g})(6)(\mathrm{i})$ (emphasis added by the court).

\footnotetext{
${ }^{79}$ The Smoky Mountain National Land Trust has since changed its name to Southwest Regional Land Conservancy.
} 
"[A]bsent these 'unexpected' and extraordinary circumstances," explained the 4th Circuit, "real property placed under easement must remain there in perpetuity in order for the donor of the easement to claim a charitable deduction."

(iii) Critical Requirements. The 4th Circuit explained that permitting a deduction for the donation of the Belk easement would enable taxpayers to bypass several requirements critical to the statutory and regulatory schemes governing deductions for charitable contributions.

- For example, permitting the Belks to change the boundaries of the easement would render "meaningless" the requirement that an easement donor obtain a qualified appraisal because the appraisal would no longer be an accurate reflection of the value of the easement, parts of which could be clawed back. "It matters not," said the court, "that the Easement requires that the removed property be replaced with property of 'equal or greater value,' because the purpose of the appraisal requirement is to enable the Commissioner, not the donee or donor, to verify the value of a donation. The Easement's substitution provision places the Belks beyond the reach of the Commissioner in this regard."

- Similarly, the baseline documentation requirement "would also be skirted if the borders of an easement could shift." "Not only does this regulation confirm that a conservation easement must govern a defined and static parcel," explained the court, "it also makes clear that holding otherwise would deprive donees of the ability to ensure protection of conservation interests by, for instance, examination of maps and photographs of 'the protected property."'

(iv) Kaufman and Simmons Distinguishable. The Belks argued that Kaufman III and Simmons II support the notion that § 170(h) does not require that easement restrictions attach to a single, defined parcel. The 4th Circuit rejected that argument, explaining that those "out-of-circuit" cases:

plausibly stand only for the proposition that a donation will not be rendered ineligible simply because the donee reserves 
its right not to enforce the easement. They do not support the Belks' view that the grant of a conservation easement qualifies for a charitable deduction even if the easement may be relocated. Indeed, as we have explained, such a holding would violate the plain meaning of $\S 170(\mathrm{~h})(2)(\mathrm{C}) .^{80}$

(v) Federal Law Controls. The Belks argued that, because North Carolina law permits parties to amend or swap easements, like a right-of-way easement between neighbors, not permitting swaps would render all conservation easements in North Carolina ineligible for a deduction under $\S 170(\mathrm{~h})$. The 4th Circuit found this argument "unpersuasive," explaining:

whether state property and contract law permits a substitution in an easement is irrelevant to the question of whether federal tax law permits a charitable deduction for the donation of such an easement ... $\S 170(\mathrm{~h})(2)(\mathrm{C})$ requires that the gift of a conservation easement on a specific parcel of land be granted in perpetuity to qualify for a federal charitable deduction, notwithstanding the fact that state law may permit an easement to govern for some shorter period of time. Thus, an easement that, like the one at hand, grants a restriction for less than a perpetual term, may be a valid conveyance under state law, but is still ineligible for a charitable deduction under federal law.

With the exception of North Dakota, which limits the duration of any easement created in the State to 99 years, it appears that the parties to a conservation easement can include provisions in the deed to comply with the federal tax law perpetuity requirements and, provided the easement is drafted appropriately, those provisions will be legally binding on both the landowner and the holder even though they impose conditions on the transfer or extinguishment of the easement that may be different or more restrictive than those imposed by state law (see Part II.A. 8 and 9 below).

\footnotetext{
${ }^{80}$ In Simmons II, the D.C. Circuit implicitly rejected the argument of the amici curiae (the National Trust for Historic Preservation et al.) that land trusts should be permitted to agree with developers to extinguish perpetual easements on some properties (to allow development) in exchange for easements on other properties. The D.C. Circuit held, in part, that an "eligible donee" must have a "commitment to protect the conservation purposes of the donation" and "the resources to enforce the restrictions" and that a tax-exempt organization would fail to enforce a conservation easement "at its peril." The D.C. Circuit also concluded that the donated easements at issue in Simmons II "will prevent in perpetuity any changes to the properties inconsistent with conservation purposes."
} 
(vi) Savings Clause Did Not Save Deduction. The substitution provision in the Belk conservation easement provided that substitutions become final when they are reflected in a formal recorded "amendment." The amendment provision in the easement provided that the land trust could not agree to any amendment that would result in the easement failing to qualify for a deduction under $\S 170(\mathrm{~h}) .{ }^{81}$ The Belks referred to this latter provision as a "savings clause." They argued that, if the 4th Circuit found that the substitution provision violated the requirements of $\S 170(\mathrm{~h})$, the savings clause would render the substitution provision inoperable, thus making the easement eligible for the deduction. In other words, the Belks argued that the savings clause would operate to negate a right clearly articulated in the easement (the right to substitute property), but only if triggered by an adverse determination by the court.

The 4th Circuit dismissed this argument, noting that the Belks were asking the court to employ the savings clause to rewrite the easement in response to the court's holding, which the court was unwilling to do. The court refused to condone such "trifling with the judicial process." The court also explained that holding for the Belks "would dramatically hamper the Commissioner's enforcement power. If every taxpayer could rely on a savings clause to void, after the fact, a disqualifying deduction ... enforcement of the Internal Revenue Code would grind to a halt."

The 4th Circuit also rejected the Belks' "last-ditch" argumentthat the savings clause was designed "to accommodate evolving ... interpretation of Section 170(h)" - explaining

the statutory language of $\S 170(\mathrm{~h})(2)(\mathrm{C})$ has not "evolved" since the provision was enacted in $1980 \ldots$... The simple truth is this: the Easement was never consistent with $\S 170(\mathrm{~h})$, a fact that brings with it adverse tax consequences. The Belks cannot now simply reform the Easement because they do not wish to suffer those consequences.

${ }^{81}$ Article VIII of the Belk easement deed provided as follows with regard to amendments:

Owner and Trust recognize that circumstances could arise which would justify the modification of certain of the restrictions contained in this Conservation Easement. To this end, Trust and the legal owner or owners of the Conservation Area at the time of amendment shall mutually have the right, in their sole discretion, to agree to amendments to this Conservation Easement which are not inconsistent with the Conservation Values or the purposes of this instrument; provided, however, that Trust shall have no right or power to agree to any amendments hereto that would result in this Conservation Easement failing to qualify as a valid conservation agreement under the "Act," as the same may be hereafter amended, or as a qualified conservation contribution under Section $170(\mathrm{~h})$ of the Internal Revenue Code and applicable regulations. 
b. Balsam Mountain. In Balsam Mountain, the Tax Court held that a conservation easement that authorized the parties, for a period of up to five years, to remove up to $5 \%$ of the land from the easement in exchange for protecting a similar amount of contiguous land was not eligible for a deduction under IRC § 170(h).

(i) The Easement. The easement at issue in Balsam Mountain, which was granted to the North American Land Trust (NALT) on 22 acres in North Carolina, allowed the landowner to, for five years following the donation, make alterations to the boundaries of the area protected by the easement, subject to the following conditions:

- the total amount of land protected by the easement could not be reduced,

- land added to the easement had to be contiguous to the originally protected land,

- land added to the easement had to, in NALT's reasonable judgment, make an equal or greater contribution to the easement's conservation purpose,

- the "location and reconfiguration of a boundary" could not, in NALT's judgment, result in any material adverse effect on the easement's conservation purposes, and

- no more than $5 \%$ of the originally protected land could be removed from the easement as a result of such alterations.

(ii) Belk Not Distinguishable. Based on Belk, the Tax Court held that the Balsam Mountain easement was not "a restriction (granted in perpetuity) on the use which may be made of the real property" as required by $170(h)(2)(C)$ and, thus, was not eligible for a deduction. The donor argued that Belk was distinguishable because the Belk easement allowed for the substitution of all of the land originally protected by the easement, while the Balsam Mountain easement allowed for the substitution of only $5 \%$ of the originally protected land. The Tax Court was not persuaded. While the court agreed that the Belk and Balsam Mountain easements were different, it said "the difference does not matter." For five years following the donation, the donor, with the approval of NALT, could change the boundaries of the area protected by the easement (i.e., extinguish the original easement in part without satisfying the judicial extinguishment, impossibility or impracticality, or proceeds requirements). Accordingly, the easement was not an interest in an identifiable, specific piece of real property and, thus, was not deductible. 
c. Bosque Canyon Ranch. In Bosque Canyon Ranch, the Tax Court denied deductions claimed by partnerships for the donation of conservation easements because, among other things, the easements permitted 47 unencumbered 5-acre homesites to be moved around the subject properties with the holder's (NALT's) approval, which would result in unencumbering acreage previously subject to the easements. Specifically, the easements permitted the homesite parcel owners and NALT to mutually agree to modify the boundaries of the homesite parcels, provided:

- in NALT's "reasonable judgment," the modification would not result in any material adverse effect on the conservation purposes of the easements,

- the size of the Homesite parcels would not be increased,

- the exterior boundaries of the property subject to the easements would not be modified, and

- the overall amount of property subject to the easements would not be decreased.

The "boundary modifications" to the homesites could cause property that was protected by the easements at the time of their donation to subsequently lose that protection without satisfaction of the judicial proceeding and other requirements in Treasury Regulation $\S 1.170 \mathrm{~A}-$ 14(g)(6). Accordingly, citing the 4th Circuit's opinion in Belk III, the Tax Court held that the easements were not "restrictions (granted in perpetuity) on the use which may be made of the real property" as required under IRC $\S 170(h)(2)(C)$.

d. The holdings in Belk, Balsam Mountain, and Bosque Canyon Ranch are consistent with:

(i) Carpenter $I$ and II, in which the Tax Court held that extinguishment of a tax-deductible easement requires a judicial proceeding. Removing land from a conservation easement, whether in connection with a swap or otherwise, constitutes an extinguishment of the easement with regard to the removed land. It allows the removed land to be used for previously prohibited purposes, such as development, thus permitting the conservation values of the removed land, which had previously been protected in perpetuity, to be destroyed.

(ii) Congress's admonition in the legislative history "that provisions allowing deductions for conservation easements should be directed at the preservation of unique or otherwise significant land areas or structures," as well as the detailed threshold 
conservation purpose and other qualification and valuation requirements that must be met to be eligible for a deduction under $\S 170(\mathrm{~h}){ }^{82}$

(iii) IRS General Information Letter regarding swaps, ${ }^{83}$ and

(iv) Instructions for Schedule D of the Form 990, which (i) explain that an easement is released, extinguished, or terminated "when all or part of the property subject to the easement is removed from the protection of the easement in exchange for the protection of some other property or cash to be used to protect some other property," and (ii) require nonprofits to annually report their conservation easement transfer, modification, and termination activities. ${ }^{84}$

8. State Law Can Render Conservation Easements Nondeductible. In Wachter, the Tax Court held that North Dakota law, which limits the duration of easements created after July 1, 1977, to a maximum of 99 years, precludes conservation easement donors in the state from qualifying for a deduction under $\S 170(\mathrm{~h})$ because easements in North Dakota cannot be granted "in perpetuity."

a. Federal Law Controls. The Tax Court in Wachter reiterated the fundamental principle that, while state law determines the nature of property rights, it is federal law that determines the federal tax treatment of those rights. Wachter confirmed that state law can render all conservation easement donations in a state ineligible for the federal deduction if state law prevents conservation easements from complying with federal requirements.

Some states have considered making changes to their state codes that could render conservation easements in the state ineligible for federal tax incentives. ${ }^{85}$ Potential easement donors and their advisors should be aware of this issue.

b. Termination in 99 Years Not So Remote as to be Negligible. The taxpayers in Wachter argued that North Dakota's 99-year limitation should be considered the equivalent of a remote future event that does

\footnotetext{
${ }^{82}$ S. Rep. No. 96-1007, 1980-2 C.B. 599, at 603.

${ }^{83}$ See supra note 27 and accompanying text.

${ }^{84}$ See supra note 25 and accompanying text.

${ }^{85}$ See, e.g., Keeping the Perpetual in Perpetual Conservation Easements, http://lawprofessors.typepad.com/nonprofit/2015/12/keeping-the-perpetual-in-perpetual-conservationeasements.html.
} 
not prevent an easement from being considered perpetual. They cited Treasury Regulation $\S 1.170 \mathrm{~A}-14(\mathrm{~g})(3)$, which provides, in part, that a

deduction shall not be disallowed ... merely because the interest which passes to, or is vested in, the donee organization may be defeated by the performance of some act or the happening of some event, if on the date of the gift it appears that the possibility that such act or event will occur is so remote as to be negligible.

The Tax Court in Wachter noted that the courts have construed the soremote- as-to-be-negligible standard to mean

'a chance which persons generally would disregard as so highly improbable that it might be ignored with reasonable safety in undertaking a serious business transaction' or 'a chance which every dictate of reason would justify an intelligent person in disregarding as so highly improbable and remote as to be lacking in reason and substance.'

The Tax Court explained that the term "remote" refers to the likelihood of the event that could defeat the donee's interest in the gift. It then explained that the likelihood of the event in Wachter that could defeat the donee's interest in the charitable gifts of the conservation easements-expiration of the easements after 99 years-was not "remote." On the date of the donation of the easements, the court explained, it was not only possible, it was inevitable that the donee would be divested of its interests in the easements by operation of North Dakota law. Accordingly, the easements were not restrictions granted "in perpetuity" and, thus, were not deductible under $\S 170(\mathrm{~h})$.

9. Interaction Between Federal and State Law. Numerous courts have addressed the interaction between federal and state law in the conservation easement context. As noted in the discussions of Carpenter I and Wachter above, while state law determines the nature of the property rights in an easement, it is federal law that determines the tax treatment of those rights. Thus, in determining whether an easement complies with federal tax law requirements, one must look to the terms of the deed and applicable state law to determine how a particular easement may, for example, be transferred or extinguished, and then ask whether the easement, so configured, satisfies federal tax law requirements.

a. In Belk III, the 4th Circuit held that $\S 170(\mathrm{~h})$ "requires that the gift of a conservation easement on a specific parcel of land be granted in perpetuity to qualify for a federal charitable deduction, notwithstanding 
the fact that state law may permit an easement to govern for some shorter period of time." Thus, while an easement that grants restrictions for less than a perpetual term, like the easement at issue in Belk, may be a valid conveyance under state law, it will be ineligible for a deduction under federal law.

b. With the exception of North Dakota, which limits the duration of any easement created in the State to 99 years, it appears that the parties to a conservation easement can include provisions in the deed to comply with the federal tax law perpetuity requirements and, provided the easement is drafted appropriately, those provisions will be enforceable under state law even though they impose conditions on the transfer or extinguishment of the easement that are different or more restrictive than those imposed by state law. As the Tax Court noted in Wachter, "[b]oth parties allege that the State law at issue here is unique because [North Dakota] is the only State that has a law that provides for a maximum duration that may not be overcome by agreement."

c. In Carpenter I, the Tax Court held that the conservation easements at issue were restricted charitable gifts, or "contributions conditioned on the use of the gift in accordance with the donor's precise directions and limitations." Restricted gift status means that the property owner and the holder of the easement (and their successors) will be bound by the terms of the deed under state law, including the restriction on transfer, extinguishment, division of proceeds, and other provisions included in the deed to satisfy federal tax law requirements. In other words, if the easement is drafted appropriately, the provisions included in the deed to satisfy federal tax law requirements should be binding on both parties under state law even though the state enabling statute may contain different or less restrictive provisions addressing transfer or extinguishment.

d. To help ensure that all future parties, the IRS, and the courts understand that the conservation easement was conveyed in whole or in part as a restricted charitable gift and is intended to be binding on the property owner and the holder of the easement (and their successors), it is suggested that consideration be given to including a provision like the following in the easement:

The grantor desires to preserve and protect forever the conservation values of the property for the benefit of this generation and all generations to come. To that end the Grantor conveys this easement as an irrevocable charitable gift to be held in trust for the benefit of the public and administered and 
enforced in accordance with the terms and for the purposes specified herein in perpetuity. The grantee has agreed to accept the gift of this easement upon the condition and affirmative understanding that the intentions of the grantor regarding future use and preservation of the property as expressed herein shall forever be honored and defended. The grantor and grantee further acknowledge and agree that the terms of this restricted charitable gift shall be binding upon each of them and their respective successors in interest in perpetuity, and such terms must be complied with notwithstanding and in addition to any applicable provisions of state law.

10. Benefits of Restricted Gift Status. In addition to helping to ensure that the parties to the easement and their successors will be bound by the easement terms, including the restriction on transfer, extinguishment, division of proceeds, and other provisions included in the deed to satisfy federal tax law requirements, restricted gift status may also have the following benefits:

a. restricted charitable gifts are highly favored by the courts, and courts might interpret charitable gifts of conservation easements in favor of accomplishing their charitable conservation purposes, rather than in favor of the free use of land,

b. restricted gifts may be excluded from the bankruptcy estates of donee charitable corporations and transferred intact to new charitable holders, ${ }^{87}$

c. actions to recover conservation easements that have been improperly transferred, released, modified, or terminated may not be barred by laches or the statute of limitations, ${ }^{88}$

\footnotetext{
${ }^{86}$ See, e.g., Jackson v. Phillips, 96 Mass. 539, 550, 556 (1867) ("gifts to charitable uses are highly favored, and will be most liberally construed in order to accomplish the intent and purpose of the donor".... "If the words of a charitable bequest are ambiguous or contradictory, they are to be so construed as to support the charity, if possible."); Board of Trustees of Univ. of N. C. v. Unknown Heirs, 319 S.E.2d 239, 242 (N.C. 1984) ("It is a well recognized principle that gifts and trusts for charities are highly favored by the courts. Thus, the donor's intentions are effectuated by the most liberal rules of construction permitted."). See also Nancy A. McLaughlin, Interpreting Conservation Easements, 29 PRoB. \& PRop. 30 (2015) (arguing that conservation easements should be interpreted in favor of accomplishing their conservation purposes rather than free use of land). But see note 62 and accompanying text (cautioning that a conservation easement should include clause stating that the parties to the easement (and their successors) intend that, notwithstanding any general rule of construction to the contrary, the easement shall be liberally construed in favor of permanently protecting the property's conservation values and carrying out the conservation purpose of the easement).

${ }^{87}$ See Evelyn Brody, The Charity in Bankruptcy and Ghosts of Donors Past, Present, and Future, 29 SETON HALL LEG. J. 471 (2005) ("the courts will try to identify those charitable assets that are restricted in such a manner that they survive the bankruptcy proceeding").

${ }^{88}$ See, e.g., Tauber v. Commonwealth, 499 S.E.2d. 839, 845 (Va. 1998) (laches may not be pled successfully as a defense in an equitable proceeding to bar the state attorney general from asserting a claim on behalf of the public to
} 
d. conservation easements should not be extinguished pursuant to the doctrine of merger if the government or nonprofit holder acquires title to the subject land because the required "unity of ownership" generally will not be present (i.e., the two estates would be "in the same person at the same time," but they generally would not be held "in the same right"), ${ }^{89}$

e. attempts by state legislatures to terminate or otherwise weaken or undermine existing conservation easements may be found unconstitutional on a number of grounds, including the prohibition on impairment of private contracts, ${ }^{90}$ and

f. the state attorney general may serve as a back-up enforcer of conservation easements. ${ }^{91}$

11. Sample Restriction on Transfer and Extinguishment Provisions. A conservation easement deed should include transfer and extinguishment provisions that comply with Treasury Regulation requirements. The following are sample provisions. ${ }^{92}$

Article $[\mathrm{x}]$. Transfer and Extinguishment

a. Restriction on Transfer. ${ }^{93}$ Grantee can transfer this Easement, whether or not for consideration, only if (a) (i) as a condition of the transfer, Grantee requires that the conservation purposes of this Easement will continue to be carried out, (ii) the transferee, at the time of the transfer,

insure that charitable assets are distributed in accord with the charitable purposes to which they should have been devoted); Trustees of Andover Theological Seminary v. Visitors of Theological Inst. in Phillips Acad. in Andover, 148 N.E. 900, 918 (Mass. 1925) ("Generally it is true that no length of time of diversion from the plain provisions of a charitable foundation will prevent its restoration to its true purpose").

${ }^{89}$ See Nancy A. McLaughlin, Conservation Easements and The Doctrine of Merger, 74 DUKE J. L. \& CONTEMP. PROBS 279 (2011). See also VA Attorney General advisory opinion (Aug. 13, 2012) (opining that conservation easements in Virginia are not extinguished by application of the common law doctrine of merger), available at http://ag.virginia.gov/Opinions\%20and\%20Legal\%20Resources/Opinions/2012opns/11-140\%20Rust.pdf.

${ }^{90}$ See Nancy A. McLaughlin \& W. William Weeks, In Defense of Conservation Easements: A Response to The End of Perpetuity, 9 WYO. L. REV. 1, 88-91 (2009) (gathering the relevant authorities).

${ }^{91}$ See, e.g., Lyme Land Conservation Trust, Inc. v. Planter, 2013 WL 3625348 (Superior Ct. of Connecticut, May 29, 2013) (unpublished); Kimberly Drelich, After Lengthy Dispute, Court Finds in Favor of Lyme Land Conservation Trust, THE DAY, Mar. 14, 2015, at A1, available at http://www.theday.com/article/20150314/NWS01/303149962 (Connecticut attorney general assisted a land trust in successfully enforcing a conservation easement on behalf the public). At least six state enabling statutes expressly grant the attorney general enforcement rights. CONN. GEN. STAT. Ann. § 47-42c (2012); 765 Ill. Comp. Stat. 120/4 (2012); Me. Rev. Stat. Ann. tit. 33, § 478(1)(D) (2012); Miss. Code Ann. § 89-19-7(1) (2012); R.I. Gen. LAWs § 34-39-3(f)(4) (2012); VA. Code AnN. § 10.1-1013 (2012). For a discussion of the attorney general's common law and statutory rights to enforce charitable gifts and trusts on behalf of the public, see CHester, Bogert \& Bogert, THe LAW OF TRUSTS \& TRUstees $\S 411$ ( $3^{\text {rd }}$ ed. 2005).

${ }_{92}$ These sample provisions are drafted to track the Treasury Regulation requirements. However, neither the IRS nor the courts have blessed these sample provisions. Readers are responsible for obtaining legal advice from their own legal counsel.

93 See Treas. Reg. $\S 1.170 \mathrm{~A}-14$ (c)(2). The cross-reference in the last sentence of this regulation to (g)(5)(ii) is incorrect and should be to $(\mathrm{g})(6)(\mathrm{ii})$; the Treasury failed to update the cross-references when it finalized the proposed regulations in 1986. Grantee should be defined in the easement to include all successors and assigns. 
is both a "qualified organization" under IRC $\S 170(h)(3)$ and eligible to receive this Easement under [citation to State $X$ conservation easement enabling statute], and (iii) the transferee has the commitment to protect the conservation purposes of this Easement and the resources to enforce, and agrees to enforce, this Easement; or (b) the transfer complies with the extinguishment requirements in [this Article]. Any attempted transfer by Grantee of all or a portion of this Easement contrary to this paragraph shall be invalid but shall not operate to extinguish this Easement. Any subsequent transfer of this Easement shall also be subject to the provisions of this paragraph.

\section{b. Extinguishment; Proceeds. ${ }^{94}$}

(1) Grantor and Grantee agree that the donation of this Easement creates a property right that immediately vests in Grantee. Grantor and Grantee further agree that this property right has a fair market value that is at least equal to the proportionate value that this Easement, at the time of the gift, bore to the value of the Property as a whole (unencumbered by this Easement) at that time, and such minimum proportionate value of Grantee's property right, expressed as a percentage (the "Minimum Percentage"), shall remain constant.

(2) This Easement can be extinguished in whole or in part (whether through release, termination, abandonment, swap, exchange, or otherwise) only (i) in a judicial proceeding in a court of competent jurisdiction, (ii) upon a finding by the court that a subsequent unexpected change in the conditions surrounding the Property has made impossible or impractical continued use of the Property (or the portion thereof to be removed from this Easement) for conservation purposes, and (iii) with a payment of proceeds to Grantee as described in the following [subparagraph], which proceeds must be used by Grantee in a manner consistent with the conservation purposes of this Easement.

(3) In the event of an extinguishment, Grantee shall be entitled to a share of the proceeds from a subsequent sale, exchange, lease, or involuntary conversion of the affected property equal to the greater of: (i) the Minimum Percentage of such proceeds or (ii) the Extinguishment Percentage of such proceeds, with "Extinguishment Percentage" defined as the proportionate value that this Easement, immediately before and ignoring the

\footnotetext{
${ }^{94}$ See id. § 1.170A-14(g)(6).
} 
extinguishment, bore to the value of the Property as a whole (unencumbered by this Easement) at that time, expressed as a percentage.

(4) Any attempted extinguishment of all or a portion of this Easement contrary to this paragraph shall be invalid

c. Supplement to State Law. The provisions of this Article shall survive any transfer and any partial or full extinguishment of this Easement and shall apply notwithstanding, and in addition to, any provisions relating to transfer or extinguishment under state law.

12. "Greater of" Proceeds Formula. The "greater of" proceeds formula in paragraph b.(3) of the sample extinguishment provision above complies with federal tax law requirements because the holder will always receive at least the Treasury Regulation's required minimum proportionate (or floor) share of proceeds. The "greater of" formula also (i) ensures that the holder will receive the appreciation (if any) in the value of easement to be used "in a manner consistent with the conservation purposes of the original contribution" (i.e., to replace lost conservation or historic values) and (ii) eliminates the property owner's perverse incentive to seek extinguishment to benefit from any appreciation in the value of the easement (i.e., the "spread" between the Minimum Percentage and the Extinguishment Percentage), which may be significant.

While the "greater of" formula may create an incentive for the easement holder to seek extinguishment, holders have a fiduciary obligation to administer and enforce conservation easements consistent with their terms and purposes; "eligible donees" must have a commitment to protect the conservation purposes of the donation and the resources to enforce the restrictions; ${ }^{95}$ and extinguishment is permitted only in a judicial proceeding and upon a court's finding that a subsequent unexpected change in the conditions surrounding the property has made impossible or impractical the continued use of the property for conservation purposes. ${ }^{96}$

13. Noncompliant "Proceeds" Clause. In Carroll, the Tax Court sustained the IRS's disallowance of approximately $\$ 650,000$ of carryover deductions claimed with regard to the donation of a conservation easement because the easement contained a noncompliant "proceeds" clause. The court explained that the minimum proportionate share of proceeds that must be payable to the holder following extinguishment is equal to the percentage determined by (i) the fair

\footnotetext{
${ }^{95}$ Treas. Reg. § 1.170A-14(c)(1).

${ }^{96}$ See Treas. Reg. § 1.170A-14(g)(6); Belk III; Carpenter II.
} 
market value of the conservation easement on the date of the gift (the numerator) over (ii) the fair market value of the property as a whole on the date of the gift (the denominator). For example, if the fair market value of an easement on the date of the gift was $\$ 300,000$, and the fair market value of the property as a whole on the date of the gift was $\$ 1,000,000$, the easement represented $30 \%$ of the value of the property on the date of the gift, and the holder must be entitled to at least $30 \%$ of the proceeds following the easement's extinguishment.

In Carroll, the conservation easement deed limited the numerator of the formula noted above to "the deduction for federal income tax purposes allowable" by reason of the donation. The court explained that, if the IRS were to disallow the deduction for reasons other than valuation and the easement were later extinguished in a judicial proceeding, the numerator would be zero and the holder of the easement would not receive the minimum proportionate share of proceeds as is required. The court also noted that deductions are denied for many reasons unrelated to valuation, and, in fact, the IRS made numerous arguments for disallowance of the taxpayers' claimed deductions in Carroll that were not based on valuation.

Although not mentioned by the court, mandating that the holder receive at least a minimum proportionate share of proceeds even if the donor's deduction is disallowed is appropriate from a policy perspective. Regardless of whether donors' deductions are allowed or disallowed, charitable gifts of easements are irrevocable and holders have an ongoing obligation to monitor and enforce the easements on behalf of the public. Given the investment that will be made by the public in monitoring and enforcement, the value attributable to the easements should not be permitted to revert to the donors (or the donors' successors in interest) upon extinguishment. Rather, such value should remain in the charitable sector and be used to replace lost conservation values, as Treasury Regulation $\S 1.170 \mathrm{~A}-14(\mathrm{~g})(6)$ requires. In addition, as in many of the cases, the IRS challenged the claimed deduction in Carroll on numerous grounds (including overvaluation and lack of a completed gift of the easement due to application of Maryland's Uniform Transfers to Minors Act). Accordingly, even if the court had found that the proceeds clause passed muster, the deduction may have been disallowed on other grounds.

The Tax Court distinguished its holding in Carroll from the 1st Circuit's holding in Kaufman. In Kaufman, the 1st Circuit held that the donors of a facade easement had satisfied the proceeds requirement because the easement deed correctly stated the proceeds formula and the donee organization had an absolute right as against the donors for its share of proceeds upon extinguishment. In Carroll, in contrast, the donee organizations would not be entitled to any proceeds in certain circumstances based on the formula included in the easement deed. 
Consistent with the 1st Circuit's reasoning in Kaufman, failing to guarantee that the donees would be entitled to at least the required minimum proportionate share of proceeds upon extinguishment, and providing a potential windfall to the donor or the donor's successors as a result, was fatal to the deduction.

The Tax Court found that the donors' deductions were not saved by the last sentence in Treasury Regulation $\S 1.170 \mathrm{~A}-14(\mathrm{~g})(6)(\mathrm{ii})$, which provides an exception to the requirement that the holder must receive at least a minimum proportionate share of proceeds upon extinguishment if "state law provides that the donor is entitled to the full proceeds from the conversion without regard to the terms of the [easement]." Maryland has an unusual provision in its state code. Pursuant to this provision, if land subject to an easement held by Maryland Environmental Trust (MET) is condemned, damages must be awarded "to the fee owner ... and shall be the fair market value of the land or interest in it, computed as though the easement ... did not exist." This presumably means the holder would receive nothing unless the parties agreed that the fee owner would give a portion of the proceeds to the holder. The Carroll easement had been granted to MET and a local land trust as co-holders. The Tax Court held that the state code provision above did not save the deduction because (i) the provision applies only to easements held by MET and, thus, the proceeds formula in the deed still violated the proceeds requirement with regard to the local land trust, and (ii) the provision applies only to condemnations and, thus, the proceeds formula in the deed still violated the proceeds requirement with regard to judicial extinguishments not based on condemnation.

The Tax Court also dismissed the taxpayers' argument that noncompliance with the proceeds requirement should be forgiven because the probability of extinguishment of the easement was "so remote as to be negligible." Citing Kaufman III, the Tax Court explained that easement donors cannot satisfy the requirements of the extinguishment regulation by merely establishing that the possibility of a change in conditions triggering judicial extinguishment is unexpected. To accept such an argument, explained the Tax Court, would nullify the requirements because the extinguishment regulation, by its terms, applies only to "unexpected" conditions.

The Tax Court further explained that, the taxpayers "could have avoided this adverse outcome by strictly following the proportionality formula set forth in the regulation." In addition, in finding that the taxpayers were liable for accuracyrelated penalties, the court noted:

[The taxpayers] offered no evidence which would explain why the terms of the conservation easement varied from the requirements of [Treasury Regulation $\S 1.170 \mathrm{~A}-14(\mathrm{~g})(6)$ ], nor do they clarify why Dr. Carroll failed to seek competent advice from a tax attorney or other adviser to ensure the 
conservation easement's compliance with pertinent regulations. In the light of Dr. Carroll's high level of sophistication and experience with conservation easements, we conclude that [the taxpayers] have not demonstrated that they acted with reasonable cause and in good faith in not seeking competent tax advice regarding the conservation easement.

There are a number of takeaways from Carroll.

- Conservation easement donations generally involve high-dollar deductions and the requirements of $\S 170(\mathrm{~h})$ and the regulations are numerous and complex. Accordingly, prospective easement donors should hire experienced tax counsel to assist them with their donations. If they do not, they run the risk of not only having their deductions denied, but also being subject to penalties for failure to seek tax advice. Too often easement donors are either unrepresented by legal counsel, or represented by legal counsel with little or no tax expertise.

- Donors of conservation easements should not rely on a donee organization or its template or model easement to satisfy the requirements for the deduction. The risks of noncompliance (audit, litigation, denial of deductions, and interest and penalties) fall solely on the shoulders of the donor, and it is the responsibility of the donor and the donor's tax counsel to ensure that all requirements are satisfied. Most donees are careful to instruct donors that they cannot and do not provide legal advice, and donors need to take that warning to heart.

- The amount of litigation in this context could be significantly reduced if the IRS developed safe harbor or "sample" conservation easement provisions to satisfy the key perpetuity requirements of $\S 170(\mathrm{~h})$. While many provisions of an easement must be tailored to the specific property and situation, many of the perpetuity requirements, including those addressing judicial extinguishment and proceeds, could be satisfied with provisions that generally should not vary from easement to easement. Safe harbor provisions would facilitate both donor compliance and IRS review, and would help to ensure that the public investment in easements and their conservation purposes is actually "protected in perpetuity" as Congress intended. Moreover, developing sample provisions would not be a novel approach to facilitating compliance and curbing abuse. The Treasury developed sample trust provisions with annotations in the charitable remainder trust and charitable lead trust contexts and those provisions, which are widely used, have greatly facilitated compliance and reduced abuses. 
14. Reimbursement of Funders on Extinguishment. Irby analyzed Treasury Regulation $\S 1.170 \mathrm{~A}-14(\mathrm{~g})(6)(\mathrm{ii})$ (the division of proceeds portion of the extinguishment regulation) as applied to conservation easements conveyed in bargain sale transactions. The conservation easements in Irby had been conveyed to a land trust, but three government entities had supplied funding to pay approximately $75 \%$ of the value of the easements to the landowners, and the landowners made charitable gifts of the remaining $25 \%$. The easements provide that the grantee (the land trust) is entitled to Treasury Regulation $\S 1.170 \mathrm{~A}-14(\mathrm{~g})(6)(\mathrm{ii})$ 's mandated minimum proportionate share of proceeds following extinguishment, but must pay $75 \%$ of those proceeds to the government entities to reimburse them for their contributions to the purchase price of the easements, which would leave the grantee with only $25 \%$ of the proceeds.

a. The IRS argued that the reimbursement obligation meant that the grantee was not actually entitled to the mandated minimum proportionate share of proceeds following extinguishment-i.e., that its entitlement was merely "superficial." The Tax Court disagreed. The court explained that, unlike the situation where a lender holding an outstanding mortgage on the property is given priority to proceeds upon extinguishment (which furthers the taxpayer's interests because the proceeds will be used to pay down the taxpayer's debt), there was no risk that the taxpayers in Irby could reap a similar windfall upon extinguishment because the proceeds payable by the grantee to the governmental entities, each of which has a conservation mission, would be used by such entities "in a manner consistent with the original conservation purposes of the contribution" (as explained in the next paragraph). Thus, the court found that the easement deeds met the requirements of division of proceeds regulation.

b. The Tax Court noted that the IRS's concerns in Irby more properly seemed to address the question of whether all of the extinguishment proceeds would be used by the grantee "in a manner consistent with the conservation purposes of the original contribution" as required by Treasury Regulation $\S 1.170 \mathrm{~A}-14(\mathrm{~g})(6)(\mathrm{i})$. The court determined that they would. It explained that all three government entities "were established to assist the conservation of open land" and are "legally obligated to fulfill their conservation purpose." In addition, the court stated that it appeared that the reimbursements would enhance the ability of the government entities "to conserve and protect more land, since the reimbursed funds would be used to do just that." Accordingly, the court found that the reimbursement provision in Irby did not violate the 
requirements of either the extinguishment or division of proceeds regulations. $^{97}$

c. The Tax Court issued stipulated decisions in Irby in December 2013 ordering the taxpayers to pay agreed upon deficiencies in income tax for taxable years 2003 and 2004, but no penalties were imposed.

\section{B. Qualified Appraisal and IRS Form 8283 (Appraisal Summary)}

\section{Short History.}

a. In 1984, as part of the Deficit Reduction Act of 1984 (DEFRA), ${ }^{98}$ Congress required taxpayers claiming deductions for noncash charitable contributions in excess of $\$ 5,000$ to obtain a qualified appraisal prepared by a qualified appraiser ${ }^{99}$ and attach an appraisal summary to the return on which the deduction is first claimed for the property contributed. DEFRA also directed the Secretary of the Treasury to prescribe regulations implementing the statutory requirements. Pursuant to this legislative mandate, the IRS and the Treasury Department promulgated Treasury Regulation $\S 1.170 \mathrm{~A}-13$ (c) (attached as Appendix D), which provides that no deduction shall be allowed for a noncash contribution in excess of $\$ 5,000$ unless the taxpayer

(i) obtains a qualified appraisal prepared by a qualified appraiser and

(ii) attaches a fully completed appraisal summary (IRS Form 8283) to the tax return on which the taxpayer first claims a deduction for the contribution.

b. In 2004, Congress added $\S 170(f)(11)$ to the Internal Revenue Code effective for contributions made after June 3, 2004 (§ 170(f)(11), as amended, is attached as Appendix E). ${ }^{100}$ Section $170(f)(11)$ provides, among other things, that

\footnotetext{
${ }^{97}$ Some have argued that the court reached the correct result in Irby, but for the wrong reason. Treasury Regulation $\S 1.170 \mathrm{~A}-14(\mathrm{~g})(6)$ (ii) could be viewed as applying only to the portion of the proceeds attributable to the contribution component of a bargain sale transaction, and not to the portion of the proceeds attributable to the sales component of the transaction. Allowing the funders to be reimbursed for the funds they contributed to the purchase price should thus not run afoul of the proceeds requirement, although the priority of the payments might be an issue.

98 Pub. L. No. 98-369, 98 Stat. 691 (1984).

99 DEFRA § 155(a). Congress defined the term "qualified appraisal" to mean an appraisal prepared by a qualified appraiser that includes, among other information: (1) a description of the property appraised, (2) the fair market value of the property on the contribution date and the specific basis for valuation, (3) a statement that the appraisal was prepared for income tax purposes, (4) the qualifications of the appraiser, and (5) any additional information the Secretary may prescribe by regulation. Id. § 155(a)(4).

${ }^{100}$ See $\S 883$ of the American Jobs Creation Act of 2004, Pub. L. No. 108-357, 118 Stat. 1418.
} 
(i) in the case of contributions of property for which a deduction of more than $\$ 5,000$ is claimed, the taxpayer must obtain a qualified appraisal and attach to the return for the taxable year in which such contribution is made such information regarding such property and such appraisal as the Secretary may require (i.e., the Form 8283, appraisal summary), ${ }^{101}$ and

(ii) in the case of contributions of property for which a deduction of more than $\$ 500,000$ is claimed, the taxpayer must attach the full qualified appraisal to the return (i.e., the entire qualified appraisal must be filed with the Form 8283). ${ }^{102}$

c. In 2006, Congress amended $\S 170(f)(11)$ to add statutory definitions of the terms "qualified appraiser" and "qualified appraisal.."

d. Later in 2006, the IRS issued Notice 2006-96, ${ }^{104}$ which, among other things, provides transitional guidance regarding $\S 170(f)(11)(E)$ 's definitions of qualified appraisal and qualified appraiser.

e. In 2008, the IRS and the Treasury Department issued proposed regulations implementing the substantiation and reporting rules. ${ }^{105}$ Until these regulations are finalized and effective, the transitional guidance in IRS Notice 2006-96 applies.

f. As the foregoing indicates, the qualified appraisal, qualified appraiser, and appraisal summary requirements are both statutory and regulatory requirements.

2. Form 8283, Section B. Despite the 1st Circuit's holding in Kaufman III, donors should correctly and completely fill out Form 8283 and attach a Supplemental Statement as described below and not rely on substantial compliance. ${ }^{106}$

\footnotetext{
${ }^{101}$ IRC § 170(f)(11)(C).

${ }^{102}$ Id. § 170(f)(11)(D).

${ }^{103}$ IRC $\S 170(f)(11)($ E). See $\S 1219$ of the Pension Protection Act of 2006, Pub. L. No. 109-280, 120 Stat. 780. For an explanation of the Pension Protection Act of 2006 changes, see Technical Explanation Of H.R. 4, The "Pension Protection Act of 2006," prepared by the JCT, JCX-38-06 (August 3, 2006), available at https://www.jct.gov/publications.html?func=select\&id=20.

${ }_{104}$ IRS Notice 2006-96 is available at http://www.irs.gov/irb/2006-46_IRB/ar13.html.

${ }^{105}$ See Substantiation and Reporting Requirements for Cash and Noncash Charitable Contribution Deductions, 73 Federal Register 45908 (proposed August 7, 2008).

${ }^{106}$ In Kaufman III, the 1st Circuit held that failure to include the date, manner of acquisition, and cost or other basis of the property contributed on the Form 8283 was not fatal to the deduction. However, in Costello the Tax Court held that the Form 8283 did not comply or substantially comply with Treasury Regulation requirements because it was not signed by the donee and it failed to disclose the consideration the taxpayers received in exchange for the purported donation. In Ney, the Tax Court similarly held that the Form 8283 did not comply or substantially comply with Treasury Regulation requirements because it was not signed by an appraiser or the donee, it did not list the date of acquisition of the properties, and it did not state that the contributions were made as part of bargain sales or indicate
} 
a. Appendix $F$ contains examples of correctly filled-out sections of the Form 8283 relating to conservation easements in various circumstances.

b. The donee and the individual appraiser or appraisers (if more than one) must all sign the Form $8283 .^{107}$

c. DEFRA specifically requires taxpayers to include on the return on which a deduction is first claimed such information as may be prescribed by Treasury Regulations, including the cost basis and acquisition date of the donated property. ${ }^{108}$ The Treasury Regulations implement this requirement by providing that the appraisal summary must include, among other things (i) the manner and date of acquisition of the property by the donor and (ii) the cost or other basis of the property. ${ }^{109}$ The Treasury Regulations also provide that, if a taxpayer has reasonable cause for being unable to provide the foregoing information, an appropriate explanation should be attached to the appraisal summary. The taxpayer's deduction will not be disallowed simply because of the inability-for reasonable cause-to provide these items of information. ${ }^{110}$

d. The Instructions for Form $8283^{111}$ state, with regard to Section B, Part I, Line 5, Columns (d) through (f) (addressing date acquired, how acquired, and basis): "If you have reasonable cause for not providing the information in columns (d), (e), or (f), attach an explanation so your deduction will not automatically be disallowed" (emphasis added).

3. Supplemental Statement. The Instructions for Form 8283 require the donor to attach a supplemental statement to the form.

a. The supplemental statement must:

(i) identify the conservation purposes furthered by the donation,

(ii) show, if before and after valuation is used, the fair market value of the underlying property before and after the gift,

(iii) state whether the donation was made in order to get a permit or other approval from a local or other governing authority and whether the donation was required by a contract (i.e., was there a quid pro quo), and

(iv) if the donor or a related person has any interest in other property nearby, describe that interest.

the compensation received in exchange. See also Seventeen Seventy Sherman Street ("failure to properly disclose a bargain sale [on a Form 8283] may foreclose a claimed charitable contribution deduction in its entirety").

107 See Treas. Reg. § 1.170A-13(c)(5)(iii).

108 DEFRA § 155(a)(1)(C).

${ }^{109}$ See Treas. Reg. § 1.170A-13(c)(4)(ii)(D) and (E).

${ }^{110}$ See id. § 1.170A-13(c)(4)(iv)(C)(1).

${ }^{111}$ Instructions for Form 8283 are available at http://www.irs.gov/pub/irs-pdf/i8283.pdf. 
b. The Supplemental Statement should be comprehensive and detailed (numerous pages long). An example of a supplemental statement is attached as Appendix G.

4. Special Rules for Façade Easement Donations. For the donation of a façade easement on a building in a registered historic district, in addition to the Form 8283 and Supplemental Statement, the taxpayer must include with the taxpayer's return for the year of the contribution: (a) a qualified appraisal, (b) photos of the entire exterior of the building, (c) a description of all restrictions on the development of the building, and $(d)$ if the deduction claimed is more than $\$ 10,000$, a $\$ 500$ filing fee. ${ }^{112}$

In Gemperle, the Tax Court sustained the IRS's disallowance of deductions claimed with regard to a 2007 donation of a façade easement because the taxpayers, a married couple who represented themselves in Tax Court, failed to include a qualified appraisal of the easement with the return they filed for the year of the contribution. The Tax Court also found the Gemperles liable for $20 \%$ penalties for "disregard of rules or regulations" under IRC § 6662(a) and (b)(1). The court explained that the requirement that the full qualified appraisal be included with the tax return filed for the year of the contribution is stated not only in the Internal Revenue Code but also in the instructions for the IRS Form 8283, and the taxpayers "were at least careless, if not reckless, in ignoring the warning that an appraisal was required." The Gemperles were alternatively liable for $40 \%$ strict liability penalties under IRC $\S 6662(\mathrm{~h})$ for making gross valuation misstatements on their 2007 and 2008 returns with regard to the easement.

\section{Qualified Appraisal Requirements}

\section{General Requirements. ${ }^{113}$}

a. Strict Compliance Recommended. Donors should strictly comply with all statutory and regulatory qualified appraisal requirements. While in some cases the courts have been willing to forgive failures to strictly comply with some of the requirements, ${ }^{114}$ in the following cases failures

\footnotetext{
${ }^{112}$ See IRC $\S \S 170(h)(4)(B)(i i i)$ and 170(f)(13). See also IRS Form 8283-V, available at http://www.irs.gov/pub/irs$\mathrm{pdf} / \mathrm{f} 8283 \mathrm{v} . \mathrm{pdf}$.

${ }^{113}$ See IRC § 170(f)(11) (attached as Appendix E); Treas. Reg. § 1.170A-13(c) (attached as Appendix D); IRS Notice 2006-96, available at http://www.irs.gov/irb/2006-46_IRB/ar13.html.

${ }^{114}$ In Zarlengo, the Tax Court held that the taxpayer complied or substantially complied with the various qualified appraisal requirements even though, among other things, the appraisal was "premature" (i.e., prepared more than sixty days prior to the date of the contribution). In Irby, the Tax Court held that an appraisal report's discussion of the purpose of the appraisal (i.e., to value an easement for purposes of $\S 170(\mathrm{~h})$ ) was sufficient to satisfy Treasury Regulation $\S 1.170 \mathrm{~A}-13(\mathrm{c})(3)(\mathrm{ii})(\mathrm{G})$ 's requirement that the appraisal contain "[a] statement that the appraisal was prepared for income tax purposes." In Simmons II, Scheidelman II, and Friedberg II, the courts held that the appraisals obtained to substantiate façade easement donations sufficiently detailed the "method used" and "basis" of valuation
} 
to strictly comply led to a complete disallowance of the claimed deductions.

(i) Lord. In Lord, the Tax Court sustained the disallowance of a deduction for the donation of a conservation easement because the taxpayer's appraisal (which did not include the easement contribution date, the date the appraisal was performed, or the appraised fair market value of the easement on the contribution date) was not a qualified appraisal. The doctrine of substantial compliance was not applicable because significant information was omitted.

(ii) Costello. In Costello, landowners conveyed a conservation easement permanently prohibiting development of their 73-acre farm to Howard County, Maryland, in exchange for the right to sell 16 development rights to a developer for $\$ 2.5$ million. The developer was able to use those rights to increase density on parcels located in a "receiving area" of the County (i.e., the exchange was pursuant to the County's transfer of development rights program). Seven months later, the landowners hired an appraiser to appraise their property before and after a "hypothetical" sale of development rights. The appraiser was unaware of the existing conservation easement and assumed the property could be developed into a 25-lot subdivision. He estimated the value of the hypothetical development rights to be $\$ 5.5$ million and the taxpayers filed a tax return claiming a charitable income tax deduction of that amount. Howard County refused to sign an IRS Form 8283 as the "donee" because it questioned whether the conveyance of the easement constituted a charitable donation.

The IRS disallowed the claimed deduction on a number of grounds, including that the taxpayers failed to obtain a "qualified appraisal." The Tax Court sustained the disallowance, finding, among other things, that the taxpayer's appraisal failed to include the following three elements required for a qualified appraisal: (a) the appraisal did not contain an accurate description of the contributed property (i.e., the appraiser didn't describe or purport to value the conservation easement because the appraiser was unaware of its existence), (b) the appraisal did not contain the date of the contribution (unsurprising given that the appraiser

for purposes of Treasury Regulation $\S 1.170 \mathrm{~A}-13(\mathrm{c})(3)(\mathrm{ii})(\mathrm{J})$ and $(\mathrm{K})$. Provision of the basis of valuation is also required by DEFRA $\S 155(a)(4)(B)$. 
was unaware of the easement conveyance), and (c) the appraisal did not contain the salient terms of any of the agreements relating to the contributed property (again, unsurprising given that the appraiser was unaware that the landowners had agreed to grant the easement to the County in exchange for the right to sell development rights for $\$ 2.5$ million).

After filing their initial income tax return and claiming a \$5.5 million deduction, the landowners apparently had second thoughts. They had their appraiser prepare an addendum to his appraisal that took into account their sale of development rights to the developer for $\$ 2.5$ million, and they filed an amended income tax return claiming a deduction of only $\$ 3$ million. However, the appraiser's addendum was not prepared within the required time period for a qualified appraisal (i.e., no more than 60 days before the gift and no later than the due date (including extensions) of the return on which a deduction is first claimed). ${ }^{115}$ The Tax Court held that the untimely addendum did not convert the original appraisal into a qualified appraisal. The court also held that the appraisal did not "substantially comply" with the reporting requirements because it omitted numerous categories of important information and appraised the wrong asset.

The Tax Court further explained that, pursuant to IRC $\S 170(f)(11)(A)(i i)(I I)$ (see Appendix E), "[e]ven absent strict or substantial compliance with the 'qualified appraisal' and reporting requirements, a deduction will not be denied if the failure to meet those requirements is due to 'reasonable cause and not to willful neglect.'" The burden of proving reasonable cause is on the taxpayer, however, and the court held that, given the magnitude of the omissions from the appraisal and the Form 8283, particularly the failure to disclose the prior sale of development rights for \$2.5 million, the taxpayers could not show that their failures were due to reasonable cause.

(iii) Mecox. In Mecox, the U.S. District Court for the Southern District of New York sustained the IRS's complete disallowance of a deduction claimed with regard to the donation of a façade easement because (i) the easement was found not to have been contributed until the year it was recorded, which was the year following the year in which the taxpayer claimed the deduction and (ii) the appraisal was untimely (i.e., the appraisal was made

${ }^{115}$ See Treas. Reg. 1.170A-13(c)(3)(i)(A) (attached as Appendix D). 
more than 60 days prior to the date of the contribution $\left.{ }^{116}\right)$. See Part III.C.2 below for a more detailed discussion of Mecox.

b. Collective Defects. After the 2nd Circuit's holding in Scheidelman II (discussed immediately below), the Tax Court in Rothman II reconsidered its earlier opinion and concluded that the Rothman appraisal met the "method used" and "basis" of valuation requirements of the Treasury Regulations. However, the Tax Court noted that Treasury Regulation $\S 1.170 \mathrm{~A}-13$, the qualified appraisal regulation (attached as Appendix D), imposes 15 distinct requirements and the appraisal in Rothman failed to satisfy 8 of the 15 requirements. Because of the "collective defects," the court reconfirmed its holding that the appraisal was not qualified. The Tax Court in Rothman II further noted that, because the qualified appraisal regulation was promulgated under an express delegation of congressional authority and has been found to be valid, the U.S. Supreme Court instructs that courts respect the lines the Secretary of the Treasury has drawn therein as a valid exercise of rulemaking authority. Whether the donor in Rothman qualified for the "reasonable cause" exception for not having a qualified appraisal under $\S 170(f)(11)(A)(i i)(I I)$ was an issue that remained to be tried, but the case settled.

c. Qualified Appraisals That Are Not Credible. In a number of façade easement cases the courts held that the appraisals met the minimal requirements of a qualified appraisal but did not provide credible evidence of value.

\section{(i) Scheidelman. In Scheidelman II, the 2nd Circuit explained}

[f]or the purpose of gauging compliance with the reporting requirement, it is irrelevant that the IRS believes the method employed [a mechanical application of a percentage diminution] was sloppy or inaccurate, or haphazardly applied-it remains a method, and [the appraiser] described it. The regulation requires only that the appraiser identify the valuation method "used"; it does not require that the method adopted be reliable.

However, the 2nd Circuit went on to explain that its conclusion that the appraisal met the minimal requirements of a qualified appraisal mandated neither that the Tax Court find the appraisal persuasive nor that Scheidelman be entitled to any deduction for the donated façade easement, and it remanded to the Tax Court.

${ }^{116} / d$. 
In Scheidelman III, the Tax Court held that, although the taxpayers' appraisal was a qualified appraisal: (a) the taxpayers did not provide sufficient credible evidence to meet their burden of establishing entitlement to the claimed charitable contribution deduction and (b) the preponderance of the evidence supported the IRS's position that the façade easement had no value.

In Scheidelman IV the 2nd Circuit affirmed the Tax Court's holding that the easement had no value. ${ }^{117}$ In support of its holding, the 2nd Circuit quoted the IRS's valuation expert, who explained that "in highly desirable, sophisticated home markets like historic brownstone Brooklyn, the imposition of an easement, such as the one granted ... does not materially affect the value of the subject property." The 2 nd Circuit also found persuasive the fact that the donee had assured one of Scheidelman's mortgagors that

[a]s a practical matter, the easement does not add any new restrictions on the use of the property because the historic preservation laws of the City of New York already require a specific historic review of any proposed changes to the exterior of this property.

(ii) Kaufman. In Kaufman III, the 1st Circuit vacated the Tax Court's opinions in Kaufman I and Kaufman II in part and remanded to the Tax Court on the issue of valuation. The 1st Circuit explained that the Kaufmans had expressed concern to the donee-the National Architectural Trust (NAT)-about the high appraised value of the façade easement they were donating because it implied a substantial reduction in the resale value of their home, which was located in Boston's South End Historic District. "In an effort to reassure them, a [NAT] representative told the Kaufmans that experience showed that such easements did not reduce resale value." "This," said the 1st Circuit, "could

\footnotetext{
${ }^{117}$ In Evans, Dunlap, Foster, Scheidelman, Kaufman, Chandler, and Reisner, façade easements on residential properties were found to have no value (in Reisner the parties so stipulated). However, courts have determined that façade easements reduce the value of the properties they encumber, albeit by less than the taxpayers' claimed, in some cases. In Simmons I, Zarlengo, and Gorra, the Tax Court held that façade easements reduced the value of the subject residential properties by 5\%, 3.5\%, and 2\%, respectively. In Seventeen Seventy Sherman Street, the IRS argued that a façade easement had no effect on the value of a historic shrine because of already existing local historic preservation restrictions. The Tax Court disagreed, holding that the easement was more protective of the shrine than local law. In Whitehouse Hotel, after two appeals, the 5th Circuit affirmed the Tax Court's holding that a façade easement encumbering the historic Maison Blanche building (which is located in the French Quarter in New Orleans and is now used as a Ritz Carlton hotel) reduced the value of the building by $14.9 \%$. For a comprehensive discussion of the valuation case law, see Nancy A. McLaughlin, Conservation Easements and the Valuation Conundrum, 19 FLA. TAX REV. 225 (2016), available at http://papers.ssrn.com/sol3/papers.cfm?abstract_id=2704576.
} 
easily be the IRS's opening argument in a valuation trial." ${ }^{118}$ And so it apparently was.

In Kaufman IV, on remand from the 1st Circuit, the Tax Court sustained the IRS's complete disallowance of the deductions claimed with regard to the façade easement donation on the ground that the easement had no value. Although the Tax Court assumed the Kaufman's appraisal was a "qualified appraisal," the court gave no weight to the appraisal's estimate of value because it found the appraiser's method (application of a standard diminution percentage to the value of the property before the easement's donation) to be unreliable and his analysis unpersuasive. The Tax Court found the IRS's valuation expert, who determined that the value of the easement was zero, to be more persuasive. The IRS's expert opined, among other things, that the typical buyer would find the restrictions in the façade easement no more burdensome than local historic preservation restrictions and, even if the façade easement were more restrictive, it would not necessarily reduce the value of the property because homeowners in historic districts place premium value on the assurance that the neighborhood surrounding their homes will remain unchanged over time.

- In Kaufman IV the Tax Court also sustained the IRS imposition of accuracy-related penalties. The indefatigable Kaufmans appealed that holding to the 1st Circuit. In Kaufman V (discussed in Part III.A.1 below), the 1st Circuit affirmed, noting that the Tax Court did not clearly err when it found that the Kaufmans were liable for penalties for claiming a deduction for the donation of "a worthless historic preservation easement on their home."

(iii) Chandler. In Chandler, the Tax Court sustained the IRS's complete disallowance of deductions claimed with regard to two façade easement donations. As in Kaufman, the properties were located in Boston's South End Historic District and the easements were donated to NAT. Relying on its analysis in Kaufman IV, the court explained that, although there were minor differences (in scope, monitoring, and enforcement) between the easement restrictions and the restrictions already imposed by local law, those differences do not affect property values because a typical

${ }^{118}$ The 1st Circuit also noted "Section 170(h) does not allow taxpayers to obtain six-figure deductions for gifts of lesser or no value." 
buyer would perceive no difference between the two sets of restrictions. The court did not find the taxpayer's appraisal, which asserted a $16 \%$ diminution in the value of the properties, to be credible. The appraiser who prepared the appraisal has been barred from preparing any kind of appraisal report or otherwise participating in the appraisal process for any property relating to federal taxes. ${ }^{119}$

d. Importance of Good Appraisals. Donors should not rely on appraisals that do not strictly comply with the qualified appraisal requirements or use questionable valuation methods or bases. While failures to strictly comply with the rules have been forgiven in some cases, in other cases they have resulted in complete disallowance of the claimed deductions. Moreover, even though an appraisal might be found to be a qualified appraisal, if it is poorly written, employs questionable methods or bases, or is otherwise unconvincing, it may nonetheless trigger an audit and, if litigated, the donor may be found to have failed to provide sufficient credible evidence of value. ${ }^{120}$ In situations where a donation has already been made and satisfaction of the qualified appraisal requirements is an issue on audit or in litigation, however, the decisions in Simmons II, Scheidelman II, Friedberg II, Irby, and Zarlengo may be helpful.

e. IRC $\S 170(f)(11)$. Most of the cases that have been decided to date involved donations made before (i) the effective date of $\S 170(f)(11)$ (June 4, 2004), (ii) enactment of the Pension Protection Act of 2006, which amended $\S 170(f)(11)$ to add statutory definitions of the terms "qualified appraiser" and "qualified appraisal," and (iii) the IRS's issuance of Notice 2006-96, which, among other things, provides transitional guidance regarding $\S 170(f)(11)(E)$ 's definitions of qualified appraisal and qualified appraiser. We can expect to see discussion of the statutory requirements in $\S 170(f)(11)$ in future cases. ${ }^{121}$

2. Conservation Easement-Specific Valuation Rules. Donors should also strictly comply with the conservation easement-specific valuation rules in Treasury Regulation $\S 1.170 \mathrm{~A}-14(\mathrm{~h})(3)$, including the "contiguous parcel" and "enhancement" rules.

a. Pursuant to the contiguous parcel rule, ${ }^{122}$ the amount of the deduction in the case of a conservation easement covering a portion of contiguous

\footnotetext{
119 See Part I.O above.

${ }^{120}$ For the IRS's view of appraisals, see Nonprofit Law Professors Blog, IRS on Conservation Easement Appraisals, at http://bit.ly/1UqHbTl.

${ }^{121}$ See supra notes 100-104 and accompanying text (discussing these statutory requirements).

122 The contiguous parcel rule is found in the fourth sentence of Treasury Regulation $\S 1.170 \mathrm{~A}-14(\mathrm{~h})(3)(\mathrm{i})$.
} 
property owned by the donor and the donor's "family" is the difference between the fair market value of the entire contiguous parcel before and after the granting of the easement.

b. Pursuant to the enhancement rule, ${ }^{123}$ if the granting of a conservation easement has the effect of increasing the value of any other property owned by the donor or a "related person," the amount of the deduction must be reduced by the amount of the increase in the value of the other property, whether or not such property is contiguous.

c. IRS Office of Chief Counsel Advice 201334039 (CCA) provides helpful guidance on the application of the contiguous parcel and enhancement rules. $^{124}$

(i) The CCA discusses the meaning of the term "family" for purposes of the contiguous parcel rule, the meaning of the term "related person" for purposes of the enhancement rule, and rules relating to constructive ownership and entity classification and their impact on both the contiguous parcel and enhancement rules. The CCA provides twelve examples of the application of these rules to various situations involving property owned by individuals and entities (LLCs, partnerships, and corporations).

(ii) The CCA also explains in a footnote that, for purposes of the contiguous parcel rule, whether the entire contiguous parcel is valued as one large property or as separate properties depends on the highest and best use of the entire contiguous parcel. ${ }^{125}$

3. File Qualified Appraisal with Income Tax Return. Consistent with the IRS'S informal suggestion, a copy of the qualified appraisal should be included in the package filed with the income tax return on which a deduction for the easement donation is first claimed even if the appraised value of the easement is $\$ 500,000$ or less. If possible, the qualified appraisal should include a copy of the recorded (date stamped) conservation easement deed. In all cases, the appraiser should have valued the restrictions as they appear in the recorded easement deed rather than in an earlier draft.

\footnotetext{
${ }^{123}$ The enhancement rule is found in the fifth sentence of Treasury Regulation $\S 1.170 \mathrm{~A}-14(\mathrm{~h})(3)(\mathrm{i})$.

124 IRS Chief Counsel Advice 201334039 (released Aug. 23, 2012), available at http://www.irs.gov/pub/irswd/1334039.pdf.

${ }^{125}$ See Nonprofit Law Professors Blog, IRS on Conservation Easement Appraisals, at http://bit.ly/1UqHbTI (discussing this issue).
} 


\section{Contemporaneous Written Acknowledgment}

1. No deduction is allowed for a charitable contribution of $\$ 250$ or more unless the taxpayer substantiates the contribution with a contemporaneous written acknowledgment (CWA) obtained from the donee. ${ }^{126}$

2. A CWA must include the following information:

a. the amount of cash and a description (but not value) of any property other than cash contributed,

b. whether the donee provided any goods or services in consideration, in whole or in part, for the contributed property, and

c. if goods and services were provided, a description and good faith estimate of the value of such goods or services. ${ }^{127}$

3. A CWA will be contemporaneous only if the taxpayer obtains it on or before the earlier of

a. the date on which the taxpayer files a return for the taxable year in which the contribution was made, or

b. the due date (including extensions) for the filing of such return. ${ }^{128}$

4. Failure of a donor to obtain a CWA cannot be cured by having the donee file a Form 990 or any other form containing the required information. ${ }^{129}$

5. In Schrimsher and French, the Tax Court held that the conservation easement deed could not serve as a CWA. See also Bruzewicz (letter identifying cash contributions relating to façade easement donation was not a CWA; doctrine of substantial compliance inapplicable) and Didonato (settlement agreement was not a CWA). In Simmons I, ${ }^{130}$ Averyt, and RP Golf, LLC, however, the Tax Court held that the conservation easement deed could serve as a CWA. And in Irby, the Tax Court held that documents associated with the bargain sale of two easements collectively constituted a CWA. In French, which is the most recent case addressing this issue, the Tax Court distinguished Averyt and RP Golf, LLC, and explained that a conservation easement deed can satisfy the "goods and services" component of the CWA requirement in two ways: (i) the deed contains a statement as to whether the donee provided goods or services for the

\footnotetext{
${ }^{126}$ IRC $\S 170(f)(8)(A)$. While not a conservation easement donation case, Van Dusen v. Comm'r, 136 T.C. 515, available at http://www.ustaxcourt.gov/InOpHistoric/VanDusen.TC.WPD.pdf, contains a detailed discussion of the CWA requirement.

127 IRC § 170(f)(8)(B).

${ }^{128}$ Id. $\S 170(\mathrm{f})(8)(\mathrm{C})$.

${ }^{129}$ See IRS Chief Counsel Advice 201120022 (May 20, 2011), available at http://www.us.kpmg.com/microsite/taxnewsflash/Exempt/2011/CCA201120022.pdf.

${ }^{130}$ In Simmons I, Tax Court Judge Goeke stated that the easement deed could serve as a CWA. However, the donee in Simmons had provided the donor with a separate letter that complied with the statutory CWA requirements, so it is not clear why the Judge addressed the issue. The judge did not fully discuss whether or how the easement deed satisfied the statutory CWA requirements.
} 
contribution or, (ii) if the deed does not contain such an explicit statement, the deed as a whole contains sufficient information to allow the IRS to determine whether taxpayers received consideration in exchange for the contribution. Given the different holdings in the cases, donors should not rely on a conservation easement deed or other documentation to serve as the CWA. Rather, donors should always obtain a separate CWA from the donee.

6. Some government entities accepting conservation easement donations refuse to provide donors with a CWA. Donors and their counsel should discuss this issue early on with a prospective government holder. To address this issue and, in general, to serve as both a good "safety valve" and a reminder to the parties, some practitioners include a statement in the easement deed that (i) no goods or services were provided in consideration for the easement (if that is the case) and (ii) the donee agrees to provide the donor with the CWA required by IRC $\S$ 170(f)(8).

7. To justify the seeming harshness of the rule that failure to comply with the CWA requirement is fatal to a claimed deduction, the Tax Court in French cited Addis v. Commissioner, 374 F.3d 881, 887 (9th Cir. 2004), in which the 9th Circuit explained that "[t]he deterrence value of section $170(f)(8)$ 's total denial of a deduction comports with the effective administration of a self-assessment and self- reporting system."

\section{E. Compelling and Timely Baseline Documentation}

1. The regulations require that the donor make available to the donee, prior to the time the donation is made, documentation sufficient to establish the condition of the property at the time of the gift ("baseline documentation"). ${ }^{131}$

a. The baseline documentation must describe in detail the subject property and its open space, habitat, scenic, historic, and other conservation values. In addition, if the easement deed contains restrictions with regard to a particular natural resource to be protected, such as water quality or air quality, then the condition of that resource at or near the time of the gift must also be established in the baseline documentation. $^{132}$

\footnotetext{
${ }^{131}$ See Treas. Reg. $\S 1.170 \mathrm{~A}-14(\mathrm{~g})(5)(\mathrm{i})$. Although this requirement is applicable only if the "donor reserves rights the exercise of which may impair the conservation interests associated with the property," that will almost always be the case. Moreover, it is common practice and recommended that this requirement be satisfied with regard to every conservation easement donation because it helps to ensure the holder will have the information needed to properly enforce the easement.

${ }^{132}$ Id. $\S 1.170 \mathrm{~A}-14(\mathrm{~g})(5)(\mathrm{i})(\mathrm{D})$.
} 
b. The baseline documentation must be accompanied by a statement signed by the donor and a representative of the donee clearly referencing the documentation and in substance stating: "This natural resources inventory is an accurate representation of [the protected property] at the time of the transfer" (referred to hereinafter as a "certification"). ${ }^{133}$

- In some cases, the parties have drafted the certification to provide that the parties agree the inventory (or baseline) may be supplemented in the future (e.g., where the baseline is prepared when the property is covered with snow). This has caused problems on audit. The baseline must be fully completed prior to the time the donation is made.

- Assuming the baseline is timely completed, easement drafters may want to include language in the easement deed confirming that the baseline is complete and the parties agree that it is an accurate representation of the protected property at the time of the donation.

c. The baseline documentation should be detailed and compelling; it is the donor's best opportunity (as part of the tax filing) to persuade the IRS that the property has important conservation or historic values worthy of preservation. In some instances, easement donees are hiring qualified consultants to put together comprehensive and extensive baseline reports. Note that the Treasury Regulations actually put the burden of delivery of the baseline on the donor (see E.1. above).

d. The baseline documentation is also critical for enforcement purposes; it provides evidence of the condition of the property, including any improvements, on the date of the donation. The Treasury Regulations explain that the purpose of the baseline is to "protect the conservation interests associated with the property, which although protected in perpetuity by the easement, could be adversely affected by the exercise of the reserved rights." ${ }^{\prime 34}$ The baseline is thus essential to ensuring that the conservation purpose of the easement is "protected in perpetuity," and failure to timely prepare a fully completed baseline could be fatal to the deduction.

2. In Bosque Canyon Ranch, the Tax Court sustained the IRS's disallowance of deductions claimed for the donation of conservation easements to the North American Land Trust (NALT). Among other failures to comply with $\S 170(\mathrm{~h})$ and

${ }^{133} / d$.

${ }^{134} / d$. § 1.170A-14(g)(5)(i). 
the Treasury Regulations, the baseline documentation NALT prepared with regard to the easements was not executed properly and was "unreliable, incomplete, and insufficient to establish the condition of the relevant property on the date the respective easements were granted." The documentation was also untimely, parts having been prepared well before and parts having been prepared well after the date of the donations. The court noted that, in "rambling, incoherent testimony," NALT's president "failed to clarify these glaring inconsistencies." The court also found meritless and rejected the taxpayers' argument that they had substantially complied with the baseline documentation requirement.

The court further found that the taxpayers were not eligible for the reasonable cause exception to the gross valuation misstatement penalty because they did not act reasonably or in good faith with respect to the baseline documentation requirement. The court noted that the taxpayers' representative failed to effectively supervise or review NALT's "slipshod" preparation of the baseline documentation and thereby failed to satisfy the taxpayers' responsibility relating to preparation of the documentation. Any reliance on NALT by taxpayers was therefore unreasonable, said the court.

3. The IRS routinely asks for the baseline documentation on audit and has informally recommended that easement donors include a copy of the baseline documentation in the package filed with the income tax return on which a deduction for the easement donation is first claimed. The baseline documentation should be filed along with the tax return if it is a good, thorough, and compelling report.

\section{F. Correct and Timely Lender Agreement (if applicable)}

1. Full Subordination is Advisable. In Kaufman III, the 1st Circuit vacated the Tax Court's holding in Kaufman I and Kaufman II that priority language in a lender agreement impermissibly limited the operation of the "proceeds" clause included in a facade easement to satisfy the requirements of Treasury Regulation $\S 1.170 \mathrm{~A}-14(\mathrm{~g})(6)(\mathrm{ii}) .{ }^{135}$ The lender agreement in Kaufman provided that, if the easement were extinguished as a result of a casualty event (such as a fire or flood) or condemnation, the bank holding an outstanding mortgage on the property had first priority to any insurance or condemnation proceeds. The 1st Circuit held that it was sufficient that the donee in Kaufman has a right to postextinguishment proceeds that is absolute against the owner of the burdened property. Despite this ruling, donors should still obtain a lender agreement that subordinates the lender's rights to all of the rights of the holder under the conservation easement, including the holder's right to at least a minimum

\footnotetext{
${ }^{135}$ Treas. Reg. $\S 1.170 \mathrm{~A}-14(\mathrm{~g})(6)(\mathrm{ii})$ contains a limited exception to the proceeds requirement with respect to involuntary conversions if state law provides that the donor is entitled to all of the proceeds following such a conversion.
} 
proportionate share of the proceeds received following extinguishment as specified in Treasury Regulation $\S 1.170 \mathrm{~A}-14(\mathrm{~g})(6)(\mathrm{ii})$, for the following reasons. $^{136}$

a. Kaufman III is good law only in the 1st Circuit.

b. In footnote 5 of Kaufman III, the 1st Circuit noted that Treasury Regulation $\S 1.170 \mathrm{~A}-14(\mathrm{~g})(2)$ (the "mortgage subordination" requirement) could be read broadly to require that a lender subordinate its rights to the donee's right to post-extinguishment proceeds, which, pursuant to Treasury Regulation $\S 1.170 \mathrm{~A}-14(\mathrm{~g})(6)(\mathrm{i})$, must be used to advance conservation purposes. ${ }^{137}$ The 1 st Circuit noted that it did not pursue this issue because the IRS had "disclaimed" that broad reading of paragraph (g)(2) in Kaufman III.

\section{c. In Irby, decided after Kaufman III, the Tax Court noted}

In cases involving a conservation easement where we determined that the regulation's requirements were not met and thus denied the claimed charitable contribution deduction, the grantee organization had been prevented by the deeds themselves from receiving the full proportionate value of the extinguishment proceeds.... The funds diverted by the deeds were used to further the donor taxpayer's interests. For example, in Wall, the deed of conservation easement provided that if the property was condemned, the grantee conservation organization would be entitled to the easement's proportionate value, but only after any claim of a mortgagee was satisfied. Hence, the first use of the extinguishment proceeds was to further the donor taxpayer's interest in repaying the mortgage on the property, with the grantee conservation organization's receiving only a residual

\footnotetext{
${ }^{136}$ For an example of such a "full" subordination clause, see the subordination agreement template of the Compact of Cape Cod Conservation Trusts, which provides:

[Name and address of financial institution] ("Mortgagee"), present holder of a mortgage from, [donors] ("Mortgagor"), recorded on [date] in the [County] Registry of Deeds in Deed Book [ ] Page [ ], for consideration paid, hereby recognizes and assents to the terms and provisions of a Conservation Restriction running to the Conservation Trust, to be recorded herewith, and agrees to subordinate and hold its mortgage subject to the terms and provisions of said Conservation Restriction to the same extent as if said mortgage had been recorded subsequent to the recording of the Conservation Restriction, and the undersigned shall, in the exercise of its rights pursuant to said instrument, recognize the terms and provisions of the aforesaid Conservation Restriction.

${ }^{137}$ The mortgage subordination regulation provides that no deduction will be permitted "unless the mortgagee subordinates its rights in the property to the right of the qualified organization to enforce the conservation purposes of the gift in perpetuity." To enforce "the conservation purposes of the gift in perpetuity" (rather than just the original easement) the holder must receive a share of proceeds upon extinguishment to be used "in a manner consistent with the conservation purposes of the original contribution." If a lender is given priority, it is possible that the holder will receive nothing. Even if the holder is given a right as against the donor, the donor may be judgment proof.
} 
amount of money.... Our conclusions in those cases (i.e., denying the deduction) reflect the purpose of the regulation.

Accordingly, it appears that the Tax Court might not follow Kaufman III in cases that are not appealable to the 1st Circuit.

\section{Mortgages Must be Subordinated at Time of Donation.}

a. Mitchell. In Mitchell III, the 10th Circuit affirmed the Tax Court's holding in Mitchell I and II that, to be eligible for a deduction for the donation of a conservation easement under $\S 170(\mathrm{~h})$, any outstanding mortgages on the underlying property must be subordinated to the rights of the holder of the easement at the time of the gift. This means the lender agreement should be recorded at the same time as the conservation easement.

(i) The Facts. The donor in Mitchell did not obtain a subordination agreement from the lender holding an outstanding mortgage on the subject property until almost two years following the date of the donation. The IRS argued that the mortgage subordination requirement in the Treasury Regulations is a bright-line requirement that requires any existing mortgage to be subordinated to the rights of the holder of the easement at the time of the gift, irrespective of the likelihood of foreclosure or any alternate safeguards. The IRS also asserted that subordination must occur at the time of the gift because, without subordination, the easement would be vulnerable to extinguishment upon foreclosure and, thus, the conservation purpose would not be protected in perpetuity as required under $\S 170(\mathrm{~h})$. The 10th Circuit agreed.

(ii) Deference to Commissioner. Citing to the U.S. Supreme Court's holding in Mayo Found. for Med. Educ. \& Research v. United States, 131 S.Ct. 704, 711 (2011), the 10th Circuit explained that, because the Commissioner promulgated the regulations under $\S 170$ (h) pursuant to the authority granted to him by Congress, the regulations are binding unless they are "arbitrary and capricious in substance, or manifestly contrary to the statute." Where Congress has delegated to the Commissioner the power to promulgate regulations, said the court, "we must defer to his regulatory interpretations of the Code so long as they are reasonable.'" Requiring existing mortgages to be subordinated to conservation easements prevents extinguishment of the easements in the event the landowners default on the mortgages. 
In this way, said the 10th Circuit, the mortgage subordination requirement is "reasonably related" to Congress's mandate in $\S 170(\mathrm{~h})(5)(\mathrm{A})$ that the conservation purpose of an easement be "protected in perpetuity."

- The 10th Circuit also rejected the donor's claim that the mortgage subordination regulation is arbitrary and capricious, and therefore unenforceable. Although declining to consider that argument because it was raised for the first time on appeal, the 10th Circuit noted that the argument would fail because the regulation is "a reasonable exercise of the Commissioner's authority to implement the statute."

(iii) Subordination Must Be Timely. The donor argued that, since the mortgage subordination regulation contains no explicit time frame for compliance, it should be interpreted to allow for subordination to occur at any time. The 10th Circuit rejected this argument, noting that the regulation "expressly provides that subordination is a prerequisite to allowing a deduction." The 10th Circuit further noted that, even if it were to view the regulation as ambiguous with respect to timing, the result would be no different because the court must defer to the Commissioner's reasonable interpretation on this point.

(iv) Functional Subordination Not Sufficient. The donor argued that strict compliance with the mortgage subordination requirement was unnecessary because the easement deed allegedly contained sufficient safeguards to protect the conservation purpose in perpetuity. The 10th Circuit rejected this argument as inconsistent with the plain language of the mortgage subordination provision. The court pointed out that the regulation contains one narrow exception to the "unambiguous" subordination requirement-for donations occurring prior to 1986. ${ }^{138}$ In the case of a pre-1986 donation, a taxpayer may be entitled to a deduction without subordination if the taxpayer can demonstrate that the conservation purpose is otherwise protected in perpetuity. The negative implication of this express, time-limited exception, said the court, is that no alternative to subordination will suffice for post-1986 donations. The court thus

${ }^{138}$ The mortgage subordination requirement first appeared when the Treasury Regulations were finalized in 1986, hence the 1986 effective date. 
declined to adopt a "functional" subordination rule for donations occurring after 1986.

(v) Likelihood of Foreclosure Irrelevant. The donor argued that strict compliance with the mortgage subordination requirement was unnecessary in her case because the risk of foreclosure was "so remote as to be negligible" (the partnership that donated the easement apparently paid its debts on time and had sufficient assets to satisfy in full the amounts due). ${ }^{139}$ The donor pointed to Treasury Regulation $\S 1.170 \mathrm{~A}-14(\mathrm{~g})(3)$, which provides that a deduction will not be disallowed merely because the interest that passes to the donee organization may be defeated by the happening of some future event, "if on the date of the gift it appears that the possibility that such ... event will occur is so remote as to be negligible." She argued that this provision acts as an exception to the mortgage subordination provision-i.e., that because the risk of foreclosure in her case was arguably so remote as to be negligible, failure to satisfy the mortgage subordination requirement should be forgiven.

- The 10th Circuit rejected this argument, holding that the "so-remote-as-to-be-negligible" provision cannot be reasonably read as modifying the strict mortgage subordination requirement. In promulgating the rules, explained the court, the Commissioner specifically considered the risk of mortgage foreclosure to be neither remote nor negligible, and therefore chose to target the accompanying risk of extinguishment of the conservation easement by strictly requiring mortgage subordination.

- The 10th Circuit also noted that, even if the regulations were unclear with respect to the interplay between the mortgage subordination and remote future event provisions, the donor would not prevail because the court is required to defer to the Commissioner's interpretation to resolve any ambiguity unless it is "plainly erroneous or inconsistent with the regulations" or there is any other "reason to suspect the interpretation does not reflect the agency's fair and considered judgment on the matter." "[I]t is reasonable," said the court, "for the Commissioner to adopt an easily-applied subordination requirement over

\footnotetext{
${ }^{139}$ A partnership of which Ms. Mitchell was a partner donated the easement. For convenience purposes, Ms. Mitchell
} is referred to as the donor in this summary. 
a case-by-case, fact-specific inquiry into the financial strength or credit history of each taxpayer." The court quoted a law review article in support of its holding:

The specific requirements in the Code and Treasury Regulations establish bright-line rules that promote efficient and equitable administration of the federal tax incentive program. If individual taxpayers could fail to comply with such requirements and claim that their donations are nonetheless deductible because the possibility of defeat of the gift is so remote as to be negligible, the Service and the courts would be required to engage in an almost endless series of factual inquiries with regard to each individual conservation easement donation. ${ }^{140}$

b. Minnick. In Minnick III, the 9th Circuit similarly affirmed the Tax Court's holding in Minnick I that, to be eligible for a deduction for the donation of a conservation easement, any outstanding mortgages on the underlying property must be subordinated to the rights of the holder of the easement at the time of the gift.

(i) Citing to Mitchell III, the 9th Circuit explained that the plain language of the mortgage subordination regulation supports the Tax Court's interpretation. The regulation specifies that "no deduction will be permitted ... unless the mortgagee subordinates its rights in the property." Strictly construed, said the 9th Circuit, that language makes clear that "subordination is a prerequisite to allowing a deduction." Since there was no dispute that Minnick's lender had not subordinated its rights in the subject property when Minnick donated the easement at issue (despite warranties in the easement deed to the contrary), under the plain meaning of the regulation no deduction was permitted.

(ii) The 9th Circuit further explained that, even if the regulation was deemed ambiguous, that would not change the outcome. Under Auer v. Robbins, 519 U.S. 452 (1997), courts defer to the IRS's reasonable interpretation of its own regulations and, as explained in Mitchell III, the IRS's interpretation is reasonable and ${ }^{140}$ Nancy A. McLaughlin, Internal Revenue Code Section 170(h): National Perpetuity Standards for Federally Subsidized
Conservation Easements Part 1: The Standards, 45 REAL PROP. TR. \& EST. L.J. 473, 505-06 (2010). 
not plainly erroneous or inconsistent with the regulation. The 9th Circuit emphasized:

An easement can hardly be said to be protected 'in perpetuity' if it is subject to extinguishment at essentially any time by a mortgage holder who was not a party to, and indeed (as here) may not even have been aware of, the agreement between the Taxpayers and a [land] trust.

(iii) In Minnick II, an unpublished opinion issued the same day as Minnick III, the 9th Circuit addressed the remaining issues in Minnick, holding for the IRS on each point.

- Like the 10th Circuit in Mitchell III, the 9th Circuit in Minnick II held that the taxpayer's failure to comply with the mortgage subordination requirement could not be excused by invoking the so-remote-as-to-be-negligible regulation; the so-remoteas-to-be-negligible provision does not override the mortgage subordination requirement.

- The Minnicks argued that their failure to obtain a timely subordination agreement should be excused because there was "verifiable evidence of original intent to enforce the easement in perpetuity" in the easement deed, which specifically stated that there were "no outstanding mortgages ... in the Property that have not been expressly subordinated to the Easement." The 9th Circuit rejected this argument, explaining that, even if the statement in the deed evidenced an intent to subordinate, intent is irrelevant. A mortgage must be subordinated at the time of the gift.

- The Minnicks argued that Idaho's cy pres doctrine, which "restricted the Minnicks from abandoning or otherwise encumbering the easement," adequately ensured that the easement would continue in perpetuity and, thus, the subordination requirement was satisfied. The 9th Circuit rejected this argument, noting that the "cy pres doctrine is inapplicable here because it has no effect on the ability of the bank holding the unsubordinated mortgage to extinguish the easement by foreclosure." Cy pres would have no effect on the ability of the bank to extinguish the easement in the event of foreclosure because the easement had been granted to the land trust subject to the mortgage and, thus, the bank's rights had priority over those of the land trust and the public. 
- The Minnicks argued that the Tax Court improperly imposed a $20 \%$ negligence penalty on them under IRC $\S 6662$ (a). The 9th Circuit rejected this argument, explaining that the Minnicks did not have reasonable cause for claiming a deduction because Mr. Minnick had a law degree and reading the Treasury Regulations would have given him notice that subordination may have been required.

(iv) Mr. Minnick (a former member of the U.S. House of Representatives from Idaho) is suing his attorney for malpractice. The Idaho Supreme Court recently ruled that the suit is not barred by the statute of limitations. ${ }^{141}$

c. RP Golf, LLC. In RP Golf II, the Tax Court sustained the IRS's disallowance of a $\$ 16.4$ million deduction for the donation of a conservation easement on two private golf courses in Kansas City, Missouri. Although the IRS challenged the claimed deduction on a number of grounds (including failure to satisfy the conservation purposes test, overvaluation, and the taxpayer's lack of ownership of a portion of the subject property), the court denied the deduction because the taxpayer failed to obtain subordination agreements at the time of the gift of the easement. The court considered and rejected the taxpayer's argument that the lenders had orally agreed to subordinate their interests before the date of the gift, finding no evidence of a binding oral or written agreement under state law. The court explained that, because the easement could have been extinguished by foreclosure after the date of the gift, the easement "was not protected in perpetuity and, therefore, was not a qualified conservation contribution."

d. So-Remote-As-To-Be-Negligible Unlikely to Cure Noncompliance With Specific Requirements. Based on the holdings in Mitchell, Minnick, and other cases, ${ }^{142}$ it seems unlikely that taxpayers will be able to excuse

\footnotetext{
${ }^{141}$ Legal Malpractice Lawyer Blog, Minnick v. Ennis, No. 41663: Supreme Court of Idaho Remands Dismissal of Legal Malpractice Case, http://www.legalmalpracticelawyer.com/2015/01/22/461/ (last visited April 25, 2015).

${ }^{142}$ In Mitchell III, the 10th Circuit noted that the D.C. Circuit in Simmons did not excuse the taxpayer from complying with the mortgage subordination requirement, or excuse noncompliance with any express precondition to taking a deduction contained in the regulations. Rather, it applied the so-remote-as-to-be-negligible provision to allow a deduction despite the risk of noncompliance with $\S 1.170 \mathrm{~A}-14$ 's more general perpetuity requirements. Thus Simmons does not support an interpretation that the so-remote-as-to-be-negligible provision will excuse noncompliance with the mortgage subordination provision's plain and specific mandate that "no deduction will be permitted ... unless" the mortgage is subordinated. The 10th Circuit also noted that Kaufman III similarly "provides little guidance." In Kaufman III the 1st Circuit held that a taxpayer was entitled to a deduction because the donation satisfied the in perpetuity requirement, but it specifically declined to address whether the taxpayer had complied with the mortgage subordination provision or to base its holding on the so-remote-as-to-be-negligible provision. In Carpenter I, the Tax Court held that the "so-remote-as-to-be- negligible" provision does not modify Treasury Regulation $\S 1.170 \mathrm{~A}-14(\mathrm{~g})(6)(\mathrm{i})$. Thus, failure to comply with the extinguishment requirements of Treasury Regulation
} 
noncompliance with any of the specific requirements in the Code or Treasury Regulations by invoking the "so-remote-as-to-be-negligible" regulation.

$\S 1.170 \mathrm{~A}-14(\mathrm{~g})(6)(\mathrm{i})$ cannot be cured by a showing that the possibility of extinguishment is so remote as to be negligible. And in Mitchell $\mathrm{l}$, the Tax Court explained that the so-remote-as-to-be-negligible standard cannot be used to avoid any of the following specific requirements: (i) Treasury Regulation $\S 1.170 \mathrm{~A}-14(\mathrm{~g})(2)$ 's mortgage subordination requirement, (ii) Treasury Regulation $\S 1.170 \mathrm{~A}-14(\mathrm{~g})(6)(\mathrm{i})$ 's judicial proceeding requirement, or (iii) Treasury Regulation $\S 1.170 \mathrm{~A}-14(\mathrm{~g})(6)(\mathrm{ii})$ 's proceeds requirement. 


\section{Other Important Issues}

A. IRS's Renewed Focus on Valuation. Following the lead of the courts (see, e.g., Scheidelman, Kaufman, Mountanos, and Gorra), the IRS has renewed its focus on easement valuation. In addition, as part of the Pension Protection Act of 2006 (the PPA), Congress expanded the circumstances under which penalties can be imposed for overvaluations.

1. Penalty Provisions. Before the enactment of the PPA, a substantial valuation misstatement (subject to a $20 \%$ penalty) existed if the value of property reported on a tax return was two times (200\%) or more of the amount determined to be the correct value. A gross valuation misstatement (subject to a $40 \%$ penalty) existed if the value reported on a tax return was four times $(400 \%)$ or more of the amount determined to be the correct value. ${ }^{143}$ Taxpayers could avoid these penalties if they made the valuation misstatement in good faith and with reasonable cause.

The PPA lowered the threshold from $200 \%$ to $150 \%$ for a substantial valuation misstatement and from $400 \%$ to $200 \%$ for a gross valuation misstatement. The PPA also eliminated the reasonable cause exception for gross valuation misstatements of charitable deduction property, making that penalty a strict liability penalty. The PPA further enacted new penalties for preparers of an appraisal to be used to support a tax position if the appraisal results in a substantial or gross valuation misstatement. ${ }^{144}$ The PPA changes apply to (i) returns filed after July 25, 2006, claiming deductions for façade easement donations and (ii) returns filed after August 17, 2006, claiming deductions for donations of easements encumbering land. ${ }^{145}$

Below is a sampling of court holdings regarding penalties.

a. Kaufman $V$. In Kaufman $V$, the 1st Circuit affirmed the Tax Court's holding in Kaufman IV that the Kaufmans were liable for gross valuation misstatement penalties for claiming a deduction "for a worthless historic preservation easement on their home." Because the Kaufmans' returns were filed before the effective date of the PPA, the gross valuation misstatement penalty was not a strict liability penalty. However, the Kaufmans were unable to avoid penalties by showing that they made a good-faith investigation of the value of the easement or acted with

\footnotetext{
${ }^{143}$ If the correct value of an easement is determined to be zero, the value claimed on the taxpayer's return is deemed to be $400 \%$ or more of the correct amount and, thus, a gross valuation misstatement. See Treas. Reg. $§ 1.6662-5(\mathrm{~g})$.

${ }^{145}$ For an explanation of the Pension Protection Act of 2006 (PPA) changes, see Technical Explanation Of H.R. 4, The "Pension Protection Act Of 2006," prepared by the JCT, JCX-38-06 (August 3, 2006), available at https://www.jct.gov/publications.html?func=select\&id=20. See also Chandler (discussing the PPA effective dates).
} 
reasonable cause and in good faith. This was due, in large part, to the following factors.

- The Kaufmans represented in a letter to the lender holding an outstanding mortgage on the subject property (for purposes of obtaining a subordination agreement) that "[t]he easement restrictions are essentially the same restrictions as those imposed by current local ordinances that govern this property."

- The Kaufmans used an appraiser that the donee-the National Architectural Trust (NAT)-both recommended and taught to do façade easement appraisals. NAT also suggested language for the appraiser to include in his appraisals, which he incorporated "almost verbatim" into all of his reports, regardless of the property involved. The 1st Circuit further noted that the appraiser "at least arguably had an incentive to calculate a high value for the easement, given that he performed appraisals for [NAT] and [NAT] received cash donations corresponding to a set percentage of the assessed value of the donated easements."

- After receiving the appraisal indicating that the easement would reduce the value of their home by $\$ 220,800$ (or by $12 \%$ ), Dr. Kaufman, an emeritus professor of statistics at MIT, expressed concern to NAT that the reduction in the resale value of the home would be so large as to "overwhelm the tax savings" from the donation. In a "smoking gun email," NAT responded that façade easements do not actually reduce the value of the properties they encumber. Among other things, the email noted:

One of our directors, Steve McClain, owns fifteen or so historic properties and has taken advantage of this tax deduction himself. He would never have granted any easement if he thought there would be a risk or loss of value in his properties.

Despite the evidence indicating that the easement had no value, the Kaufmans proceeded to claim a $\$ 220,800$ deduction. The 1 st Circuit agreed with the Tax Court that "the Kaufmans should have recognized obvious warning signs indicating that the appraisal's validity was subject to serious question, and should have undertaken further analysis in response." The 1st Circuit further noted that the Tax Court did not purport to equate "good faith investigation" with "exhaustive investigation." Rather, it "merely required that the Kaufmans do some basic inquiry into the validity of an appraisal whose result was squarely 
contradicted by other available evidence glaringly in front of them." The Kaufmans were highly intelligent and very well educated, said the 1st Circuit, ${ }^{146}$ "and the Tax Court reasonably found that developments casting doubt on the ... appraisal should have alerted them that they needed to take further steps to assess their 'proper tax liability.'”

The 1st Circuit also noted that decisions in which the courts have declined to impose penalties (Whitehouse, Chandler, Zarlengo, and Scheidelman) were not inconsistent with its conclusion to impose penalties in Kaufman V. In contrast to Kaufman, there were no "red flags" in those other cases suggesting that the easements had no value.

b. Chandler. In Chandler, the Tax Court sustained the IRS's complete disallowance of deductions claimed with regard to two façade easement donations on the same grounds as in Kaufman (i.e., the easements had no value because the typical buyer would find the easement restrictions no more burdensome than local historic preservation restrictions). The taxpayers in Chandler claimed deductions with regard to the easement donations on their 2004, 2005, and 2006 returns and, because the Tax Court determined the easements had no value, the valuation misstatement for each year was a gross valuation misstatement. Chandler raised the novel issue of whether the taxpayers could assert the reasonable cause defense for the underpayment on their 2006 return (despite the PPA having made the gross valuation misstatement penalty a strict liability penalty with regard to returns filed after August 17, 2006) because the underpayment was the result of a carryover of deductions from their 2004 return. The taxpayers argued that denying their right to raise a reasonable cause defense with regard to their 2006 return would amount to retroactively applying the PPA. The Tax Court disagreed, noting that (i) the penalty statute as revised by the PPA by its plain language applies to returns filed after a certain date and (ii) when the taxpayers filed their 2006 return they "reaffirmed" the easement's grossly misstated value. For similar holdings, see Reisner and Mountanos III.

The court in Chandler did, however, find that the taxpayers were not liable for penalties for their 2004 and 2005 underpayments because they underpaid with reasonable cause and in good faith. The IRS argued that Mr. Chandler should have known the easements were overvalued because he was well educated (he had a JD and an MBA). The Tax Court disagreed, noting that even experienced appraisers find valuing conservation easements difficult, and the flaws in the appraisals would

${ }^{146}$ Mrs. Kaufman was a company president with a Ph.D. in psychology. 
not have been evident to the Chandlers. The court also distinguished Kaufman because the Kaufmans had been assured by the donee that their easement would not reduce the value of the property. In Chandler there was no evidence that the taxpayers had similarly relied on appraisals in bad faith.

c. Mountanos. In Mountanos I, the Tax Court held that the taxpayer was not entitled to claim \$3.39 million of carryover deductions for the donation of a conservation easement because he failed to show that the easement had any value. The statute of limitations had apparently run on the return on which the taxpayer claimed a deduction for the year of the donation. The court also sustained IRS's imposition of strict liability gross valuation misstatement penalties.

In Mountanos II, in what the Tax Court noted was "a calculated maneuver to avoid the accuracy-related penalty," the taxpayer asked the court to consider the alternative grounds on which the IRS had argued for disallowance of the deductions-namely that the taxpayer failed to obtain a contemporaneous written acknowledgment or a qualified appraisal. The Tax Court refused to consider these alternative grounds, noting, in part, that the continued viability of the line of cases on which the taxpayer relied for the proposition that an overvaluation penalty may not be imposed when there is some other ground for disallowing a deduction is in question after the U.S. Supreme Court's opinion in U.S. v. Woods, 134 S. Ct. 557 (2013). ${ }^{147}$ For a similar holding, see Bosque Canyon Ranch.

In a short unpublished opinion, Mountanos III, the 9th Circuit affirmed the Tax Court's holdings that the taxpayer was not eligible for the contested carryover deductions and was liable for strict liability gross valuation misstatement penalties. Citing to Chandler, the 9th Circuit rejected the landowner's argument that not allowing him to raise the reasonable cause defense for gross valuation misstatements with regard to carryover deductions that related to a 2005 donation constituted an improper retroactive application of the strict liability penalty.

d. Bosque Canyon Ranch. In Bosque Canyon Ranch, the Tax Court denied \$15.9 million of deductions claimed by partnerships for the donation of conservation easements to the North American Land Trust (NALT) on two grounds: (i) the easements permitted 47 unencumbered 5-acre homesites to be moved around the subject properties (i.e., partial

${ }^{147}$ In Woods, the Supreme Court held that the IRS's determination that a partnership was a sham was not independent from a taxpayer's overstatement for purposes of the gross valuation misstatement penalty. 
extinguishments) with the holder's approval (see Part II.A.7 above) and (ii) the partnerships failed to provide the donee with adequate and timely baseline documentation (see Part II.E above). The court also sustained the IRS's imposition of gross valuation misstatement penalties with regard to the claimed deductions. The fact that the deductions were disallowed for failure of the easements to qualify under IRC $\S 170(\mathrm{~h})$ rather than on overvaluation grounds did not matter. The Tax Court explained that, in U.S. v. Woods, 134 S. Ct. 557 (2013), the U.S. Supreme Court "reject[ed] the distinction between legal and factual valuation misstatements."

Moreover, neither partnership was eligible for the reasonable cause exception. One of the partnerships had filed its return after August 17, 2006, and, thus, the gross valuation misstatement penalty was a strict liability penalty. In addition, even though the other partnership was entitled to raise the reasonable cause defense (because it filed its return before August 17, 2006), the court determined that it did not qualify for the defense. Although the court found that the appraisal the partnership used to substantiate its deduction was a qualified appraisal and the partnership's reliance on the appraisal constituted a good faith investigation of the easement's value, that was not good enough. The court explained that the partnership "did not act reasonably or in good faith with respect to the [baseline] documentation requirements." The baseline, which was prepared by NALT, was "insufficient, unreliable, and incomplete." The partnership failed to effectively supervise or review NALT's "slipshod preparation" of the baseline and therefore "failed to satisfy its responsibility relating to the preparation of the documentation." The partnership also "failed to make any plausible contentions sufficient to establish reasonable cause."

e. Gorra. In Gorra, the Tax Court rejected the taxpayers' argument that the gross valuation misstatement penalty was an "excessive fine" under the Eighth Amendment to the United States Constitution, noting that such penalties are remedial in nature, not "punishments," and are an important tool because they enhance voluntary compliance with tax laws.

f. Legg. In Legg, the Tax Court held that the IRS's determination that the Leggs were liable for strict liability $40 \%$ gross valuation misstatement penalties was proper. The Leggs argued that the IRS examiner had not made an "initial determination" of the $40 \%$ penalties as required by IRC $\S 6751(b)(1)$ because the examination report calculated the penalties using the $20 \%$ rate and the $40 \%$ penalties were posed only as an alternative position. The Tax Court disagreed, explaining that Congress 
enacted IRC $\S 6751(\mathrm{~b})$ to ensure that taxpayers understand the penalties imposed on them and the examination report sent to the Leggs clearly explained why the Leggs were liable for the $40 \%$ penalties. Accordingly, the IRS satisfied the procedural requirements of IRC $\S 6751(\mathrm{~b})$ and imposition of the $40 \%$ penalties was proper.

g. Carroll. In Carroll, the Tax Court sustained the IRS's disallowance of deductions claimed with regard to the donation of a conservation easement because the easement contained a noncompliant "proceeds" clause. The court also found that the taxpayers were liable for $20 \%$ accuracy-related penalties and did not qualify for the reasonable cause exception to those penalties. The court explained that one of the taxpayers was a highly educated medical school graduate who had previous experience with conservation easements; although the taxpayers had hired an attorney to draft a related gift deed for the subject property, that attorney was not a tax attorney and " $d[i d]$ not answer tax-related questions or give tax advice;" the taxpayers offered no evidence that would explain why the terms of the easement varied from the proceeds requirement in the Treasury Regulation; and the taxpayers did not explain why they failed to seek competent advice from a tax attorney or other adviser to ensure that the easement complied with the pertinent regulations. The court concluded that, in the light of the high level of sophistication of one of the taxpayer's and his experience with conservation easements, the taxpayers did not demonstrate that they acted with reasonable cause and in good faith in not seeking competent tax advice regarding the donation. The court declined to impose substantial or gross valuation misstatement penalties, however, because the IRS did not assert those penalties on a timely basis.

2. Battle of the Appraisers. When the value of a conservation easement is challenged, the case often involves a "battle of the appraisers."

a. Courts no longer take the two appraisals from the expert witnesses and "split the baby." Instead, courts generally weigh the evidence offered by each expert and come to their own conclusions regarding value. In a battle of the appraisers, the credibility of the appraiser and the appraisal report is of paramount importance, and extensive experience in the relevant local market- "geographic competence" - can also be key.

b. In Boltar, the Tax Court granted the IRS's motion in limine to exclude from evidence the report and testimony of the donor's valuation expert as unreliable and irrelevant, citing to the Federal Rules of Evidence and the decision in Daubert v. Merrell Dow Pharm., Inc., 509 U.S. 579 (1993), in which the United States Supreme Court stressed the "gatekeeper" 
function of a trial court. The court noted that the report was "so far beyond the realm of usefulness that admission is inappropriate and exclusion serves salutary purposes."

c. In U.S. v. Richey, 632 F.3d 559 (9th Cir. 2011), the 9th Circuit held that the attorney-client privilege did not extend to documents in a conservation easement appraiser's work file that were not made for the purpose of providing legal advice. The work file was also not protected by the work-product doctrine because it was not "prepared or obtained because of the prospect of litigation."

d. In U.S. v. Clower, No. 1:16-cv-651-TCB (N.D. Ga. April 29, 2016), a U.S. District Judge granted the IRS's petition to enforce a broad summons served on an appraiser. The summons requested, among other things, all documents reflecting the customers for whom the appraiser prepared or approved conservation or historic easement appraisals during the period beginning January 1,2010 , through the present, and all appraisal work files for such appraisals (see Part I.W above).

3. Valuation Case Law. For a comprehensive discussion of conservation and facade easement valuation rules and the relevant valuation case law through 2015, see Nancy A. McLaughlin, Conservation Easements and the Valuation Conundrum. ${ }^{148}$

B. IRS Focus on Partnerships/Syndicated Deals. In Notice 2004-41, the IRS stated that it intended to review promotions of transactions involving improper deductions for conservation easement conveyances, and that promoters, appraisers, and other persons involved in these transactions may be subject to penalties. ${ }^{149}$ The IRS has also informally indicated that it intends to focus attention on "syndicated" conservation easement donation transactions. The IRS has a number of weapons in its arsenal that can be used to attack such syndicated transactions.

\section{IRS Weapons.}

a. Economic Substance Doctrine. Most syndicated tax deduction transactions are arguably nothing more than the sale of income tax deductions, with no economic substance and no economic risk to the investors. Pursuant to IRC $\S 7701(0)$, a transaction generally is treated as having economic substance only if (i) the transaction changes in a meaningful way (apart from Federal income tax effects) the taxpayer's

\footnotetext{
${ }_{148}$ Available at http://papers.ssrn.com/sol3/papers.cfm?abstract_id=2704576.

${ }^{149}$ See supra note 7 and accompanying text.
} 
economic position and (ii) the taxpayer has a substantial purpose (apart from Federal income tax effects) for entering into the transaction.

b. Partnership Allocation Rules. For partnership allocations to be respected they must either (i) be made in accordance with the partners' interests in the partnership or (ii) meet the requirements for the "substantial economic effect" safe harbor. If allocations do not have substantial economic effect, they will be reallocated according to the partners' interests in the partnership. These rules are intended to prevent partners from allocating partnership items based on purely tax rather than economic consequences. ${ }^{150}$

Many syndicated conservation easement donation transactions involve "special allocations"-i.e., an investor purchases a small percentage interest in a partnership or limited liability company (LLC), but is then allocated a much larger percentage of the deduction (or, in some cases, tax credits) generated by the partnership's donation of a conservation easement. For example, an investor might purchase a $10 \%$ interest in a partnership, but then be allocated $50 \%$ of the deduction generated by the partnership's easement donation. This could be referred to as an "explicit" special allocation; it occurs by virtue of specific terms in the partnership or LLC agreement. In some syndicated conservation easement donation transactions it could be argued that there is an "implicit" special allocation. For example, assume the asset in the partnership (or LLC) has a fair market value of \$5 million, an investor purchases a $10 \%$ interest in the partnership (with a pro rata value of $\$ 500,000)$ for $\$ 100,000$, and the investor is allocated $10 \%$ of the conservation easement deduction. For the $\$ 100,000$ purchase price, the investor arguably purchased only a $2 \%$ interest in the partnership but was nonetheless allocated $10 \%$ of the deduction. These types of special allocations may be attacked on the ground that they lack "substantial economic effect."

c. Disguised Sales Rules. In each of SWF Real Estate, LLC, and Route 231, LLC v. Comm'r, 810 F.3d 247 (4 ${ }^{\text {th }}$ Cir. 2016), the IRS successfully invoked a different tax avoidance principle-the "disguised sales" rules under IRC $\S$ 707-to attack the special allocation of state income tax credits generated by a partnership's donation of a conservation easement. The courts held that each partnership's transfer to a $1 \%$ partner of more than $90 \%$ of the state income tax credits generated by the donation was a taxable disguised sale. In Route 231, LLC, the 4th Circuit explained that

150 See IRS, Partnership Audit Techniques Guide, Chapter 6 - Partnership Allocations, available at http://www.irs.gov/Businesses/Partnerships/Partnership---Audit-Technique-Guide---Chapter-6---Partnership-

Allocations-(Revised-12-2007). 
IRC $\S 707$ "prevents use of the partnership provisions to render nontaxable what would in substance have been a taxable exchange if it had not been 'run through' the partnership."

Most recently, in Bosque Canyon Ranch, the Tax Court held that two partnerships' transfers of 5-acre homesites on a shared-amenities ranch to limited partners in exchange for purported "capital contributions" were, in fact, taxable disguised sales. The court found that the distributions of the 5-acre homesites to the limited partners were made in exchange for the limited partners' payments and were not subject to the entrepreneurial risks of the partnerships' operations. Accordingly, the partnerships were required to recognize and include in their gross income any gains relating to the disguised sales. The Tax Court also denied the deductions claimed by the partnerships for the donation of conservation easements with respect to the ranch for failure to satisfy the perpetuity and baseline documentation requirements.

2. Land Trust Alliance on Syndicated Deals. The Land Trust Alliance distributed an "Important Advisory" and other information and resources to its constituent land trusts to help them identify and mitigate threats from abusive syndicated transactions. ${ }^{151}$ The Alliance notes that "[f]ederal tax benefits resulting from the donation of a conservation easement cannot be sold by one taxpayer to another" and "[t]he Alliance stands against such tax schemes...." The Alliance describes the abusive transactions as follows:

outside investors fund land acquisition through various partnerships or limited liability companies. After a short holding period, the entities donate conservation easements to land trusts and claim deductions based on appraised values of the conservation easements that are significantly in excess (often by three to ten times) of the original acquisition prices.

This results in exaggerated tax benefits to the investors that are worth significantly more than the investors' initial investments. Typically, promoters organize these transactions in return for high fees. Sometimes promoters offer extraordinary stewardship donations to the participating land trusts. ${ }^{152}$

The Alliance has recommended that "member land trusts evaluate their existing easement acquisition policies and procedures and incorporate...Cautionary

\footnotetext{
${ }^{151}$ See Land Trust Alliance, For Land Trusts, Syndication, http://www.landtrustalliance.org/taxonomy/term/150.
}

152 Land Trust Alliance, Important Advisory: Syndication, http://www.landtrustalliance.org/node/590. 
Measures to assure that they do not facilitate or participate in abusive transactions." 153

For a proposed legislative fix to the syndication problem, see Stephen J. Small, $A$ Modest Legislative Proposal to Shut Down Specific Tax Shelters, Tax Notes Special Report (May 23, 2016). ${ }^{154}$

C. Date of Donation and Recordation Date. Treasury Regulation $\S 1.170 \mathrm{~A}-14(\mathrm{~g})(1)$ provides that

any interest in the property retained by the donor (and the donor's successors in interest) must be subject to legally enforceable restrictions (for example, by recordation in the land records of the jurisdiction in which the property is located) that will prevent uses of the retained interest inconsistent with the conservation purposes of the donation.

The donor of a conservation easement should see to it that the easement is recorded in the year in which the donor intends to claim the donation was made. Absent recordation of an easement, a purchaser of the subject property who records the purchase deed will generally take the property free of the easement. In addition, many state conservation easement enabling statutes specifically require recordation for an easement to be legally enforceable. ${ }^{155}$ Accordingly, absent recordation in the year of the purported donation, the IRS can argue that the easement was not "granted in perpetuity" and its conservation purpose was not "protected in perpetuity" in that year.

1. IRS's Position on Recordation. The IRS's position on recordation is set forth in the Conservation Easement Audit Techniques Guide. ${ }^{156}$ The Guide instructs that the complete deed of conservation easement (including all exhibits or attachments, such as a description of the easement restrictions, diagrams, and lender agreements) must be recorded in the appropriate recordation office in the county where the property is located and, under state law, an easement is not enforceable in perpetuity before it is recorded. ${ }^{157}$ The Guide further instructs that the effective date of the gift is the recording date, and provides the following as an example:

\footnotetext{
${ }^{153} / d$. (emphasis in original).

${ }^{154}$ Available at http://www.stevesmall.com/wordpress/wp-content/uploads/Small-05-23-2016.pdf.

${ }^{155}$ For example, the Uniform Conservation Easement Act provides that "[n]o right or duty in favor of or against a holder and no right in favor of a person having a third-party right of enforcement arises under a conservation easement before its acceptance by the holder and a recordation of the acceptance." Uniform Conservation Easement Act $\S 2$ (b) (Last Revised or Amended in 2007), available at http://www.uniformlaws.org/shared/docs/conservation_easement/ucea_final_81\%20with\%2007amends.pdf.

${ }^{156}$ See IRS CE Audit Techniques Guide, supra note 23.

157 Id. at 15.
} 
A conservation easement was granted to a qualified organization on December 20, 2007, as evidenced by the dated signatures on the conservation easement deed. However, the easement was not recorded in the public records until March 12, 2008. The year of donation is $2008 .^{158}$

\section{Case Law.}

a. Gorra. Gorra involved a donation to the National Architectural Trust (NAT) of a façade easement on a building in the Carnegie Hill Historic District of New York City. NAT delivered the easement to the recorder's office on December 28, 2006, paid the recording fees and taxes, and obtained a receipt for the delivery. Due to a cover sheet error, however, the easement was not recorded until January 18, 2007. The IRS argued that the deed was not recorded until 2007. The Tax Court disagreed, holding that, under New York law, delivery of the deed to the recorder's office, with receipt acknowledged, constituted recordation, even though there was a delay in the actual recording until the following year because of the cover sheet error. The court cited N.Y. Real Prop. Law $\S 317$, which provides that every instrument entitled to be recorded is considered recorded from the time of delivery to the recording officer.

b. Zarlengo. Zarlengo involved a donation to NAT of a façade easement on a building in a Manhattan historic district. The easement donors and NAT signed the easement in 2004, NAT sent the donors a letter thanking them for the donation in 2004, and the donors claimed deductions for the donation on their 2004 returns. For reasons not explained in the Tax Court's opinion, however, the easement was not recorded until January 26, 2005. The IRS argued that the taxpayers were not entitled to deductions in 2004 because the façade easement was neither (i) a "qualified real property interest" as defined in $\S 170(h)(2)(C)$ (i.e., "a restriction (granted in perpetuity) on the use which may be made of the real property") nor (ii) donated exclusively for conservation purposes as required under $\S 170(\mathrm{~h})(5)$ (i.e., the conservation purpose of the easement was not "protected in perpetuity") in 2004.

In analyzing these issues, the Tax Court first reiterated the well settled rule that, "[i]n a Federal tax controversy, State law controls the determination of a taxpayer's interest in property while the tax consequences are determined under Federal law." Accordingly, New York law governed when the taxpayers' donation of the façade easement was regarded as complete, but Federal tax law determined the tax

158 Id. at 13. 
consequences. Because New York law provides that conservation easements in the state have no legal effect unless they are recorded, the court found that the façade easement was not effective until January 26, 2005. ${ }^{159}$ Unlike in Gorra, the façade easement in Zarlengo presumably was not delivered to the recording office in 2004 and thus, was not considered recorded in that year.

The Tax Court further explained that, even assuming the façade easement had been legally enforceable by NAT against the donors in 2004 because both parties signed the easement that year, the easement still would not have satisfied the perpetuity requirements in 2004 "because neither the use restriction nor the conservation purpose of the conservation easement was protected in perpetuity until January 26, 2005." The court explained that, if a buyer had purchased the subject townhouse and recorded the purchase deed before January 26, 2005, the buyer would have taken the townhouse free and clear of the conservation easement. Moreover, the possibility that this could have occurred was not so remote as to be negligible.

The Tax Court concluded that the donors in Zarlengo were not entitled to deductions on their 2004 returns because the perpetuity requirements were not satisfied in 2004, and it followed that the donors were also not entitled to carryover deductions on subsequent years' returns. However, the IRS had acknowledged that the easement could be considered "made in perpetuity" in 2005 for purposes of $\S 170(h)(2)(C)$ and $(5)(A)$ because the easement was recorded in that year, and the Tax Court determined that "both the use restriction and the conservation purpose of the conservation easement were protected in perpetuity as of January 26, 2005." Accordingly, given that the other requirements of $\S 170(\mathrm{~h})$ and the substantiation requirements were satisfied, the donors' tax liability for 2005, 2006, and 2007 could be redetermined assuming the donation had been made in $2005 .^{160}$

c. Mecox. Mecox involved a donation to NAT of a façade easement on a building in New York's Greenwich Village Historic District. The donor (the Mecox partnership) and NAT signed the easement in December 2004 and Mecox claimed a \$2.21 million deduction for the donation on its 2004 partnership tax return. However, the easement was not recorded until

\footnotetext{
${ }^{159}$ The Tax Court held similarly in Rothman I.

${ }^{160}$ See also Satullo (although decided on lack of mortgage subordination grounds, the Tax Court stated "Georgia law clearly provides that until an easement is recorded its intended property restrictions are legally unenforceable" and "although the Deed of Gift created an easement that was accepted by [the land trust] during December 1985, its terms were not enforceable as required by [Treas. Reg. § 1.170A- 14(g)(1)] until January 19, 1988, when it was recorded").
} 
November 17, 2005, almost one year later. The IRS disallowed the claimed deduction in full, arguing that (i) the contribution was not made until 2005, the year in which the easement was recorded, and (ii) the appraisal was not timely because it was made more than 60 days before the date of the contribution. The U.S. District Court for the Southern District of New York held for the IRS on both counts.

As in Zarlengo and Rothman I, the District Court found that, as a matter of law, Mecox had not made a charitable contribution of the façade easement in 2004 because the easement was not effective under New York law until it was recorded in November 2005. The District Court further explained that, even if the court were to accept that the date the easement was contributed was the date of the delivery of the deed to NAT, the easement still did not satisfy $\S 170(h)$ 's definition of a "qualified conservation contribution" until the easement was recorded in 2005 (i.e., the conservation purpose of the contribution was not "protected in perpetuity" and the underlying property was not "subject to legally enforceable restrictions" until 2005). Absent recordation, a purchaser of the property who recorded the purchase deed would take the property free of the easement.

Mecox argued that, because the easement did not specifically reference the New York conservation easement enabling statute, that statute did not apply and the easement was a common law restrictive covenant that does not require recordation to be effective. The court dismissed that argument, finding that there was "no question" that the easement fell under the New York enabling statute's definition of a conservation easement.

Failure to record the easement until November 2005 also rendered Mecox's appraisal untimely. The appraisal was dated June 13, 2005, and estimated the value of the easement as of November 1, 2004. The court found that the appraisal was "conducted" on June 13, 2005, but the easement was not "contributed" to the National Architectural Trust (NAT) until it was recorded on November 17, 2005 (5 months later). Accordingly, the appraisal "took place" more than 60 days before the contribution date and thus, did not satisfy the timing requirement in Treasury Regulation $\S 1.170 \mathrm{~A}-13(\mathrm{c})(3)(\mathrm{i})$.

3. The Finer Points of Delivery and Recording. In many jurisdictions, where the recording offices are backed up, a document may be delivered to the recording office in December but not recorded by the office staff until January or even later. As explained in the discussion of Gorra above, in some states, like New York, delivery to the recording office constitutes recording, but that may not be 
the rule in all states. In addition, many conservation easement deeds have an "effective date" provision that says the easement is effective when it is signed and recorded. Legal counsel to donors should consider whether it would be prudent to instead include a provision in an easement deed stating that the easement is effective when the deed is signed and "delivered for recording." In addition, the person who delivers the signed easement deed to the recording office should obtain a date-stamped copy indicating the delivery date. At the very least, easement holders, donors, and their advisors should be aware of this issue.

D. Quid Pro Quo. A charitable contribution is not deductible if it is structured as a quid pro quo exchange. ${ }^{161}$ Treasury Regulation $\S 1.170 \mathrm{~A}-14(\mathrm{~h})(3)(\mathrm{i})$ provides:

- If, as a result of the donation of a [conservation easement], the donor or a related person receives, or can reasonably expect to receive, financial or economic benefits that are greater than those that will inure to the general public from the transfer, no deduction is allowable under this section.

- However, if the donor or a related person receives, or can reasonably expect to receive, a financial or economic benefit that is substantial, but it is clearly shown that the benefit is less than the amount of the transfer, then a deduction under this section is allowable for the excess of the amount transferred over the amount of the financial or economic benefit received or reasonably expected to be received by the donor or the related person. ${ }^{162}$

1. Pollard. In Pollard, the Tax Court sustained the IRS's disallowance of a deduction of more than $\$ 1$ million claimed with respect to a conservation easement conveyance because the conveyance was part of a quid pro quo

\footnotetext{
${ }^{161}$ Hernandez v. Comm'r, 490 U.S. 680, 681 (1989) ("The legislative history of the 'contribution or gift' limitation reveals that Congress intended to differentiate between unrequited payments to qualified recipients, which are deductible, and payments made to such recipients with some expectation of a quid pro quo in terms of goods or services, which are not deductible.").

${ }^{162}$ See Rev. Rul. 76-185 (from which the Treasury Regulation language appears to be derived, and which provides that "payments made by the taxpayer for the restoration and maintenance of the historic mansion and its grounds are not deductible as charitable contributions ... unless the taxpayer can establish that the payments exceed the monetary value of all benefits received or expected to be received"). See also United States v. Amer. Bar Endowment, 477 U.S. 105 (1986) ("The sine qua non of a charitable contribution is a transfer of money or property without adequate consideration. The taxpayer, therefore, must at a minimum demonstrate that he purposely contributed money or property in excess of the value of any benefit he received in return."); Treas. Reg. § 1.170A-1(h)(1) ("No part of a payment that a taxpayer makes to or for the use of an organization described in section 170 (c) that is in consideration for ... goods or services ... is a contribution or gift within the meaning of section 170 (c) unless the taxpayer-(i) Intends to make a payment in an amount that exceeds the fair market value of the goods or services; and (ii) Makes a payment in an amount that exceeds the fair market value of the goods or services."); Treas. Reg. § 1.170A-1(h)(2)(i) ("The charitable contribution deduction under section 170(a) for a payment a taxpayer makes partly in consideration for goods or services may not exceed the excess of - (A) The amount of any cash paid and the fair market value of any property (other than cash) transferred by the taxpayer to an organization described in section 170(c); over (B) The fair market value of the goods or services the organization provides in return.").
} 
exchange. The taxpayer had purchased a 67-acre parcel in Boulder County, Colorado, and had to obtain approval from the county to increase the property's building density. After public hearings, the board of county commissioners agreed to grant the taxpayer's subdivision exemption request, which allowed the property to be split into two residential lots, provided the taxpayer granted a conservation easement encumbering the property to the county.

a. The taxpayer in Pollard maintained that no quid pro quo arrangement existed, arguing, among other things, that approval of his subdivision exemption request had been "virtually guaranteed," that the land use code sections governing his exemption request did not require the grant of a conservation easement, and that all documents relating to the grant of the easement referred to it as a "gift." One of the county commissioners even wrote a letter to the taxpayer (apparently at the taxpayer's request in preparation for the Tax Court trial) stating that, to the best of his recollection, he did not require the taxpayer to grant the easement in exchange for the subdivision exemption.

The Tax Court was not persuaded. Based on its examination of the "external features of the transaction," the court found that the subdivision exemption request was far from being virtually guaranteed and, in fact, had little chance of being granted without the taxpayer's promise to grant the easement. ${ }^{163}$ The taxpayer also did not establish that the value of the easement he conveyed to the county exceeded the value of the subdivision exemption granted to him, or that he intended to make a charitable contribution. ${ }^{164}$

b. The Tax Court sustained the IRS's imposition of an accuracy-related penalty in Pollard, finding that the taxpayer did not act with reasonable cause and in good faith in claiming the deduction. The evidence produced at trial, said the court, demonstrated that all of the parties involved understood that the easement was contributed for the express purpose of encouraging the county to grant the taxpayer a subdivision exemption, and it would be unreasonable for the court to believe that anyone involved in the transaction (i.e., the taxpayer, his advisers, or the county commissioners) believed there was an unrequited contribution. ${ }^{165}$

\footnotetext{
163 In ascertaining whether a given payment is a contribution or gift, or is made with the expectation of quid pro quo, the IRS and the courts examine "the external features of the transaction," thus avoiding the need to conduct an imprecise inquiry into the motivations of individual taxpayers. Hernandez v. Comm'r, 490 U.S. 680, 701-702 (1989). ${ }^{164}$ See supra note 162.

${ }^{165}$ See also Boone v. Comm'r, T.C. Memo 2013-101 (conveyance of fill to city not a deductible charitable contribution because taxpayer failed to meet its burden of proving that the fair market value of the fill exceeded the fair market value of the consideration received in exchange); Perlmutter v. Comm'r, 45 T.C. 311 (1965) (transfers of land to school districts and a recreation district in accordance with zoning regulations were not charitable contributions); Ottawa Silica Co. v. U.S., (Ct. Cl. Trial Div.), 49 A.F.T.R.2d 82-1162, 82-1 USTC P 9308 ("It is ... quite apparent that plaintiff conveyed the land to the school district fully expecting that as a consequence of the construction of public access
} 
2. Seventeen Seventy Sherman Street. In Seventeen Seventy Sherman Street, the Tax Court sustained the IRS's complete disallowance of an LLC's claimed \$7.15 million deduction for the conveyance of interior and exterior easements restricting the use of a shrine in Denver, Colorado, because the conveyance was part of a quid pro quo exchange. The shrine is listed on the National Register of Historic Places and as a historic landmark by the City and County of Denver. The LLC owned two properties on Sherman Street-the shrine and a parking lot. Prior to granting the easements, the LLC and the City of Denver entered into a development agreement in which, among other things, the LLC agreed to convey the easements to Historic Denver and rehabilitate the shrine in exchange for certain zoning changes to the shrine and the parking lot.

a. The Tax Court's opinion detailed the following elements of a quid pro quo analysis in the charitable deduction context.

- A taxpayer's contribution is deductible 'only if and to the extent it exceeds the market value of the benefit received.'

- '[t]he sine qua non of a charitable contribution is a transfer of money or property without adequate consideration.'

- 'a charitable gift or contribution must be a payment made for detached and disinterested motives. This formulation is designed to ensure that the payor's primary purpose is to assist the charity and not to secure some benefit personal to the payor.'

- The consideration received by the taxpayer need not be financial. Medical, educational, scientific, religious, or other benefits can be consideration that vitiates charitable intent.

- In ascertaining whether a given payment was made with the expectation of anything in return, courts examine the external features of the transaction. This avoids the need to conduct an imprecise inquiry into the motivations of individual taxpayers.

- The taxpayer claiming a deduction must, at a minimum, demonstrate that "he purposely contributed money or property in excess of the value of any benefit he received in return."

- Thus, a taxpayer who receives goods or services in exchange for a contribution of property may still be entitled to a charitable deduction if the taxpayer (1) makes a contribution that exceeds the fair market value of the benefits received in exchange and (2) makes the excess payment with the intention of making a gift. ${ }^{166}$

- If the taxpayer satisfies these requirements, the taxpayer is entitled to a deduction not to exceed the fair market value of the property the

roads through its property it would receive substantial benefits in return"); Small, Real Estate Developers and Conservation Easements-Not as Simple as it Sounds, 19-JUN PROB. \& PROP. 24 (2005).

${ }^{166}$ See supra note 162. 
taxpayer transferred less the fair market value of the goods or services received. ${ }^{167}$

b. The Tax Court explained that a quid pro quo analysis in the conservation easement donation context ordinarily requires two parts-(1) valuation of the contributed conservation easement and then (2) valuation of the consideration received in exchange for the easement. The court explained, however, that when a taxpayer grants a conservation easement as part of a quid pro quo exchange and fails to identify or value all of the consideration received, the taxpayer is not entitled to a deduction because he failed to comply with IRC $\S 170$ and the regulations. In such a case, it is unnecessary to determine either the value of the easement or whether the taxpayer made an excess payment with the intention of making a gift. The taxpayer's failure to identify or value all of the consideration received and, thus, to prove that the value of the easement exceeded the value of the consideration is fatal to the deduction. ${ }^{168}$

c. In Seventeen Seventy Sherman Street, the Tax Court found that the LLC had received two types of consideration in exchange for its conveyance of the interior and exterior easements:

- a zoning change that eliminated authorization to develop residential condominium units within the shrine but also permitted development on the parking lot up to 650 feet, subject to a "view plane" restriction of 155 feet (a view plane restriction limits the height of buildings from a specified view point within Denver's city park and is meant to preserve the view of the Rocky Mountain Skyline from that view point), and

- the Denver Community Planning and Development Agency's recommendation to the Denver Planning Board to approve a view plane variance (which variance was ultimately approved).

On its 2003 tax return, however, the LLC claimed a \$7.15 million charitable deduction for its conveyance of the easements and made no adjustment for the consideration it received in exchange. At trial, the LLC conceded that it had received the zoning change in exchange for its conveyance of the easements and argued that its deduction should be reduced by just over $\$ 2$

\footnotetext{
${ }^{167}$ See Id.

${ }^{168}$ See also Cohan v. Comm'r, T.C. Memo. 2012-8, in which the Tax Court upheld the IRS's complete disallowance of a charitable income tax deduction claimed with respect to a bargain sale transaction because the contemporaneous written acknowledgment (CWA) the donee provided to the donor did not include a description or good faith estimate of the total consideration provided to the donor, and the donor's reliance on the CWA was therefore unreasonable. The court explained that "the deterrence value of $\S 170(f)(8)$ 's total denial of a deduction comports with the effective administration of a self-assessment and self-reporting system."
} 
million as a result. The LLC also asserted that the Planning and Development Agency's recommendation to the Planning Board to approve a view plane variance was either not consideration received in exchange for the grant of the easements, or was consideration but had no real value. The Tax Court disagreed, finding that the Agency's view-plane-variance recommendation was consideration and had substantial value. The court concluded that the LLC's failure to identify or value all of the consideration received, or to provide any credible evidence to permit the court to accurately value all of the consideration received, was fatal to the deduction.

d. Also notable is that the consideration the LLC received in exchange for its conveyance of the easements did not come from the donee, Historic Denver, but instead came from the City of Denver. The IRS argued that the LLC failed to substantiate its claimed deduction because it failed to (i) obtain a contemporaneous written acknowledgment (CWA) meeting the requirements of IRC $\S 170(f)(8)$ or (ii) disclose that the contribution was part of a bargain sale on Form 8283. The LLC argued that IRC $\S 170(f)(8)$ requires a donor to obtain a CWA providing a good-faith estimate of the value of the consideration received from the donee (i.e., Historic Denver), and it received no consideration from Historic Denver. The LLC also argued that the grant of the easements to Historic Denver was not a bargain sale because it received no consideration from Historic Denver and, thus, it was not required to report the conveyance as a bargain sale on the Form 8283. The Tax Court found these contentions "dubious." The court noted that the grant of the easements was a complex negotiation among the LLC, the city, and Historic Denver, and Historic Denver's role was largely as the city's designee to hold the easements. The court thus generally found persuasive the IRS's argument that the consideration received should have been disclosed on the CWA and the Form 8283. However, because the court denied the deduction in full on quid pro quo grounds, it did not decide these substantiation issues.

e. The Tax Court also agreed with the IRS that the LLC was liable for the accuracy-related penalty because it acted negligently or in disregard of the requirements of $\S 170$ and the regulations. "Negligence," said the court, is strongly indicated where a taxpayer fails to make a reasonable attempt to ascertain the correctness of a deduction that would seem to a reasonable and prudent person to be "too good to be true." And a taxpayer acts with "disregard" when, among other things, he does not exercise reasonable diligence to determine the correctness of a return position. The LLC conveyed the easements as part of a quid pro quo exchange but reported the conveyance on its 2003 return as a charitable contribution without making any adjustment for the consideration it received in exchange. The court found that the LLC acted negligently or with disregard because it did not make a reasonable attempt to ascertain the correctness of the deduction. 
The LLC argued that it was eligible for the reasonable cause and good faith exception to the penalty because it relied on professional advice. The Tax Court disagreed. Although the LLC had consulted with a tax attorney regarding the conveyance, that attorney testified at trial that he had advised the LLC that it had to reduce the value of its deduction by the consideration received in the quid pro quo exchange. The Tax Court noted that it would be unreasonable for the court to believe that at the time of the contribution or at the time of filing the LLC's return either the LLC or its advisers believed that the contribution of the easements was an unrequited contribution or that the consideration received had no value. Consequently, the LLC's disregard of the attorney's advice was not reasonable and in good faith, and the LLC could not rely on the professional advice of the attorney to negate the penalty.

3. Costello. In Costello, taxpayers conveyed a conservation easement to Howard County, Maryland, in exchange for the right to sell 16 development rights to a developer pursuant to the County's transfer of development rights program. The right to sell the development rights was conditioned on the conveyance of the easement, which prohibited any future development of the subject property. In filing their tax return and claiming a deduction for the conveyance of the easement, the taxpayers failed to indicate that they had received the right to sell the development rights (and \$2.5 million on their sale) as a result of the conveyance. The Tax Court held that, even if the taxpayers had complied with the qualified appraisal and appraisal summary requirements (which they did not), the court would nonetheless disallow the deduction because the easement was conveyed as part of a quid pro quo exchange.

The taxpayers argued that easement's value exceeded the $\$ 2.5$ million of consideration they received in exchange for its conveyance (in the form of proceeds from their sale of the 16 development rights). The Tax Court dismissed that argument because (i) the taxpayers failed to provide evidence that the property could have been developed into more than 16 lots and (ii) the taxpayers could not sell the 16 development rights until they had placed the easement on the property and, once they did, all future development was prohibited, so there was no "excess" development potential that they could have contributed to the County in the form of a bargain sale.

The Tax Court sustained the IRS's imposition of accuracy-related penalties in Costello, explaining, in part, that the taxpayers "knew or reasonably should have known" that the sale of the development rights for $\$ 2.5$ million was relevant in determining the deduction to which they would be entitled. 
4. Pesky. In Pesky, the IRS asserted not only that the taxpayer's conveyance of a conservation easement was made in exchange for a quid pro quo, but also that the taxpayer was liable for a civil fraud penalty under IRC § 6663. IRC §6663 imposes a $75 \%$ penalty on tax underpayments due to fraud. Fraud is defined as an "intentional wrongdoing on the part of the taxpayer with the specific intent to avoid a tax known to be owing." The government must prove fraud by clear and convincing evidence, but intent can be inferred from strong circumstantial evidence.

After a review of the facts and circumstances surrounding the easement conveyance, the District Court was unable to conclude that a reasonable jury could find it "highly likely" that the taxpayer's deduction was due to fraud. Because the government did not produce sufficient evidence to meet its burden of showing fraud by clear and convincing evidence, the court granted the taxpayer's motion for summary judgment on the issue. The court determined, however, that other issues could not be resolved on summary judgment, including whether the conveyance of the easement was made in exchange for quid pro quo and whether the taxpayer obtained a contemporaneous written acknowledgment accurately reflecting any goods and services provided by the donee in exchange for the contribution. It is understood that the parties in Pesky settled the case after the District Court rejected the fraud claim.

E. Side Agreements. In Graev, the Tax Court sustained the IRS's disallowance of deductions claimed with regard to the donation to the National Architectural Trust (NAT) of both a façade easement valued at $\$ 990,000$ and an accompanying $\$ 99,000$ cash contribution. NAT had written a side letter to Mr. Graev, the donor, promising that, if the deduction for the easement were disallowed, NAT would "promptly refund [Mr. Graev's] entire cash endowment contribution and join with [him] to immediately remove the facade conservation easement from the property's title." The Tax Court disallowed the deductions for both the easement and cash contributions because the gifts were conditional and, at the time they were made, the possibility they would be defeated was not so remote as to be negligible.

1. Section 170 and the corresponding Treasury Regulations provide instructions and limitations that, at least in part, ensure that a donor will be able to deduct no more than what the donee organization actually receives. Three such limitations effectively provide that no deduction for a charitable contribution will be allowed unless, on the date of the contribution, the possibility that the donee's interest in the contribution will be defeated is "so remote as to be negligible." Those limitations are found in regulation $\S 1.170 \mathrm{~A}-1(\mathrm{e})$ (pertaining to conditional gifts), regulation $\S 1.170 \mathrm{~A}-7$ (pertaining to partial interest gifts), and regulation $\S 1.170 \mathrm{~A}-14(\mathrm{~g})(3)$ (pertaining to gifts of conservation easements). 
2. Based on the facts in Graev, the court found that, on the date of the contributions, the possibility the IRS would disallow the easement deduction and NAT would return the cash to Mr. Graev and remove the easement (i.e., the gifts would be defeated) was not so remote as to be negligible. The facts the court found persuasive included the IRS's announced intention to scrutinize deductions for facade easement donations; Mr. Graev's insistence that NAT issue the side letter; NAT's practice of issuing side letters, the very essence of which "implies a non-negligible risk;" the enforceability of the side letter under state law; and NAT's incentive to honor its promises in the side letter so as not to impair its ability to obtain future contributions.

3. The possibility that a gift will be defeated will be considered so remote as to be negligible only if it is "so highly improbable that one might ignore it with reasonable safety in undertaking a serious business transaction" or "so highly improbable and remote as to be lacking in reason and substance." ${ }^{169}$ In Graev, the court explained: "the mere fact that he required the side letter is strong evidence that, at the time of Mr. Graev's contribution, the risk that his corresponding deductions might be disallowed could not be (and was not) 'ignored with reasonable safety in undertaking a serious business transaction.'" Obtaining the side letter also indicated that Mr. Graev did not think the chance of disallowance was "so highly improbable and remote as to be lacking in reason and substance." Accordingly, the mere fact of obtaining a side letter such as that at issue in Graev may be a tripwire that destroys deductibility.

F. Reserved Development Rights. Several regulatory requirements apply to retained development rights.

- Treasury Regulation $\S 1.170 \mathrm{~A}-14(\mathrm{~d})(4)(\mathrm{v})$ contains a specific limitation on the reservation of rights in an open space easement-a deduction will not be allowed "if the terms of the easement permit a degree of intrusion or future development that would interfere with the essential scenic quality of the land or the governmental conservation policy being furthered by the donation."

- Treasury Regulation $\S 1.170 \mathrm{~A}-14(\mathrm{~g})(1)$ provides that "any interest in the property retained by the donor ... must be subject to legally enforceable restrictions ... that will prevent uses of the retained interest inconsistent with the conservation purposes of the donation" (the "general enforceable in perpetuity" requirement).

- Treasury Regulation $\S 1.170 \mathrm{~A}-14(\mathrm{e})(2)$ provides that "a deduction will not be allowed if the contribution would accomplish one of the enumerated

${ }^{169}$ Briggs v. Comm'r, 72 T.C. $646,656-57$ (1979). 
conservation purposes but would permit destruction of other significant conservation interests" (the "no inconsistent use" requirement). ${ }^{170}$

1. Examples 3 and 4. The Treasury Regulations provide two examples addressing "future development" in an open space easement. ${ }^{171}$

Example 3 involves Greenacre, a 900-acre parcel of woodland, rolling pasture, and orchards on the crest of a mountain, all of which is clearly visible from a nearby national park. The highest and best use of Greenacre is as a subdivision of 40-acre tracts (potentially twenty-two residential lots). The landowner wishes to donate a scenic easement on Greenacre and would like to reserve the right to subdivide Greenacre into 90-acre parcels with no more than one single-family home allowable on each parcel. Example 3 provides that "[r]andom building on the property, even as little as one home for each 90 acres [a total of only ten homes], would destroy the scenic character of the view. Accordingly, no deduction would be allowable."

Example 4 assumes the same facts, except not all of Greenacre is visible from the park and the deed of easement allows for limited cluster development of no more than five nine-acre clusters with four houses on each cluster (for a total of twenty homes) located in areas generally not visible from the national park and subject to site and building plan approval by the donee organization to preserve the scenic view from the park. Example 4 further provides that the donor and the donee have "already identified sites where limited cluster development would not be visible from the park or would not impair the view," and owners of homes in the clusters will not have any rights with respect to the surrounding Greenacre property that are not also available to the general public. Example 4 concludes that the donation qualifies for a deduction.

Example 3 evidences the Treasury Department's dislike of reserved "floating" building sites, or rights to build that can be exercised anywhere on the property. Such rights could (i) interfere with the essential scenic quality of the land or the governmental conservation policy being furthered by the donation, ${ }^{172}$ (ii) permit destruction of other significant conservation interests, ${ }^{173}$ and (iii) permit uses of

\footnotetext{
${ }^{170}$ The regulations provide, as an example, that the preservation of farmland will not qualify for a deduction if, under the terms of the easement, a significant naturally occurring ecosystem could be injured or destroyed by the use of pesticides in the operation of the farm. Treas. Reg. $\S 1.170 \mathrm{~A}-14(\mathrm{e})(2)$. A use that is destructive of conservation interests is permitted only if the use is necessary for the protection of the conservation interests that are the subject of the contribution, such as allowing site excavation that may impair scenic values on property preserved as an archaeological site. Id. § 1.170A-14(e)(3).

${ }^{171}$ Treas. Reg. § 1.170A-14(f), Examples 3 and 4.

172 See Treas. Reg. § 1.170A-14(d)(4)(v) (limitation on reserved rights in open space easements).

${ }^{173}$ See Treas. Reg. § 1.170A-14(e)(2) (no inconsistent use requirement).
} 
the retained interest inconsistent with the conservation purposes of the donation. $^{174}$

Example 4 suggests that, even if the number of permitted homes is increased (from ten to twenty), if the homesites are clustered, located in areas generally not visible from the nearby park, and subject to site and building plan approval by the donee to preserve the scenic view, the donation will be deductible. However, Example 4 provides that the donor and the donee had, at the time of the donation, "already identified sites where limited cluster development would not be visible from the park or would not impair the view"-i.e., it did not appear that the donee was granted the discretion to, at some later time, approve sites that, in its judgment, would preserve the scenic view. Rather, it appears that sites were identified at the time of the donation, thus allowing the IRS (and, if litigated, a court) to assess whether the reserved rights (i) interfered with the essential scenic quality of the land or the governmental conservation policy being furthered by the donation, (ii) would result in the destruction of other significant conservation interests, or (iii) would involve uses of the retained interest inconsistent with the conservation purposes of the donation.

Reserved rights to develop could be addressed in a number of ways:

- the parties could identify the building sites in the conservation easement deed,

- the parties could identify more building sites in the conservation easement deed than are permitted to be used (e.g., the easement may reserve to the grantor the right to build two additional single-family residences on the subject property, but four possible sites for the two residences may be identified in the deed),

- the parties could exclude the building sites from the legal description of the property encumbered by the conservation easement (the drawback to this approach is that the holder would have no ability to limit intensive uses of the excluded land), or

- the parties could designate all sensitive areas as "no-build" areas," but the no-build areas must be more than just token setbacks; they must be sufficiently protective of the subject property's conservation values.

It is not clear from Example 4 if having rights with respect to the surrounding Greenacre property available to the general public was necessary to the outcome.

${ }^{174}$ See Treas. Reg. § 1.170A-14(g)(1) (general enforceable in perpetuity requirement). 
G. PLRs Recommending Revocation of Tax-Exempt Status. ${ }^{175}$ The IRS has issued a number of Private Letter Rulings (PLRs) recommending revocation of the tax-exempt status of organizations holding conservation easements based on fairly egregious facts. ${ }^{176}$ These PLRs illustrate some of the issues the IRS has focused on when examining organizations that accept and hold conservation easements.

1. Although the PLRs are impossible to accurately summarize in an outline because of their highly fact specific nature, some of the problems noted in the PLRs include:

- the organization served as a vehicle for its founder, the founder's family, or other related parties to donate conservation easements and claim deductions;

- the easements donated to the organization did not satisfy the conservation purpose test under $\S 170(\mathrm{~h})(4)$ (e.g., the preservation was not pursuant to a clearly delineated government conservation policy; the easement encumbered ordinary farmland with no unique features like native plants, trees, or animals; or the easement encumbered land in a gated condominium tennis resort and contained a private miniature golf course used for the pleasure of the residents only);

- the organization did not take steps to ensure that the easements it accepts serve a conservation purpose (e.g., the organization's officers, trustees, and employees did not have backgrounds or expertise in botany, biology, ecological sciences, or other fields that would enable them to credibly process or evaluate the property, or no baselines were obtained or consisted of one page or one paragraph reports; or the organization was unaware of the extensive retained rights in the easements it accepted);

- the organization did not monitor the easements it accepted on a regular basis (or at all), did not have the commitment to protect the conservation purposes (if any) of the donations, and did not have the resources to enforce the easements should enforcement become necessary;

- there was no one associated with the organization that had any formal education, training, or expertise in conservation matters;

- the organization allowed one of its easement-encumbered properties to be damaged by illegal dumping and vehicles, and another, located in an exclusive small waterfront residential development, to be encroached

\footnotetext{
${ }^{175}$ A Private Letter Ruling (PLR) is a written statement issued to a taxpayer that interprets and applies tax laws to the taxpayer's specific set of facts. A PLR may not be relied on as precedent by other taxpayers or IRS personnel. PLRs are generally made public after all information has been removed that could identify the taxpayer to whom it was issued. See IRS, Understanding IRS Guidance - A Brief Primer, available at http://www.irs.gov/uac/Understanding-IRSGuidance-A-Brief-Primer.

${ }^{176}$ See, e.g., PLR 201044026; PLR 201048045; PLR 201109030; PLR 201110020; PLR 201405018. See also PLR 201234029 (organization created for the purpose of carrying on a for-profit hay farm on property that is not ecologically significant or open to the public is not operated for an exempt purpose).
} 
upon by the residents who constructed, among other things, large ponds and a boat and recreational vehicle storage facility for the exclusive use of the residents;

- the organization amended a conservation easement to allow additional development for a fee;

- the easements the organization acquired violated the perpetuity requirement under $\S 170(\mathrm{~h})$ because the organization had the right to terminate the easements;

- the organization did not develop or sponsor any educational events, solicit the general public for support, or appear to hold itself out to the public as a charitable conservation organization; and

- the organization was not operated in accordance with it bylaws (e.g., there were no meetings of officers or board members, no elections, and no internal controls, and there was only the bare minimum with regard to records and recordkeeping).

2. PLR 201048045 explains:

To establish that it operates exclusively for charitable conservation purposes under section 501(c)(3), an organization must do more than merely accept and hold easements for which donors are claiming charitable contribution deductions under section 170(h). The organization must establish that any accepted easements actually serve a conservation purpose. The organization must also operate as an effective steward to ensure that the easement continues to further a conservation purpose. The easement is a set of legal rights. It can serve conservation purposes only if enforced where necessary. The need for enforcement can be determined only through monitoring. The extent of an organization's due diligence and monitoring activities, combined with its capacity for and commitment to enforcement when necessary, becomes highly significant in determining whether accepting and holding easements actually furthers a charitable conservation purpose and thus whether an organization with the primary purpose of accepting and holding easements qualifies for exemption under section 501(c)(3).

H. State Tax Credits. A number of states offer state income tax credits to donors of conservation easements.

1. Tax Treatment of Sale of State Tax Credits. Esgar involved three taxpayers, each of whom donated a conservation easement on land located in Colorado, received transferable income tax credits from Colorado as a result of the donation, and sold a portion of the credits to third parties within two weeks. The taxpayers reported the proceeds from the credit sales as long-term capital gain, short-term capital gain, and ordinary income, respectively. After an audit of the 
taxpayers' income tax returns, the IRS determined that the proceeds from the sales of the credits should have been reported as ordinary income.

In Tempel v. Comm'r, 136 T.C. 341 (2011), the Tax Court held that the taxpayers' state tax credits were zero-basis capital assets and, given the short holding periods, income from the sale of such credits was short-term capital gain. Several months later, the IRS released Chief Counsel Advice 201147024, which addresses the tax consequences of the sale of state tax credits to both the seller and the buyer. ${ }^{177}$

The taxpayers appealed both Esgar I (in which the Tax Court held that the taxpayers had substantially overvalued the conservation easements) and Tempel to the 10th Circuit. In Esgar II, the taxpayers argued that their state tax credits, which they held for only about two weeks, were nonetheless long-term capital assets because they held the underlying real properties for longer than one year, they relinquished development rights in those properties through the donation of the easements, and they received the tax credits because of the donations. The 10th Circuit disagreed, noting that the Tax Court correctly concluded in Tempel that the taxpayers had no property rights in the tax credits until the easement donations were complete and the credits were granted, and the credits never were, nor did they become, part of the taxpayers' real property rights. The 10th Circuit also agreed with the Tax Court that the taxpayers' holding period in the credits began at the time the credits were granted and ended when taxpayers sold them, and since the taxpayers sold the credits in the same month in which they received them, the gains from the sale of the credits were short-term capital gains.

The 10th Circuit also summarily rejected the argument that the transactions amounted to some sort of like-kind exchange of conservation easements for tax credits that might result in the "tacking" of holding periods. The court further noted that if these were like-kind exchanges it would negate the charitable nature of the taxpayers' contributions of the easements.

2. Nonpro rata Allocation of State Tax Credits was Disguised Sale. As noted in Part III.B.1 above, in each of SWF Real Estate, LLC, and Route 231, LLC v. Comm'r, 810 F.3d 247 ( $4^{\text {th }}$ Cir. 2016), the IRS successfully invoked the "disguised sales" rules under IRC $\S 707$ to attack the nonpro rata allocation of state income tax credits generated by a partnership's donation of a conservation easement.

${ }^{177}$ Chief Counsel Advice 201147024 is available at http://www.irs.gov/pub/irs-wd/1147024.pdf. 
Appendix A

Internal Revenue Code $\S 170(\mathrm{~h})$

\section{(h) Qualified conservation contribution.}

(1) In general. For purposes of subsection (f)(3)(B)(iii), the term "qualified conservation contribution" means a contribution--

(A) of a qualified real property interest,

(B) to a qualified organization,

(C) exclusively for conservation purposes.

(2) Qualified real property interest. For purposes of this subsection, the term "qualified real property interest" means any of the following interests in real property:

(A) the entire interest of the donor other than a qualified mineral interest,

(B) a remainder interest, and

(C) a restriction (granted in perpetuity) on the use which may be made of the real property.

(3) Qualified organization. For purposes of paragraph (1), the term "qualified organization" means an organization which--

$(A)$ is described in clause (v) or (vi) of subsection (b)(1)(A), or

(B) is described in section 501(c)(3) [IRC Sec. 501(c)(3)] and--

(i) meets the requirements of section 509(a)(2) [IRC Sec.

509(a)(2)], or

(ii) meets the requirements of section 509(a)(3) [IRC Sec. 509(a)(3)] and is controlled by an organization described in subparagraph $(A)$ or in clause (i) of this subparagraph.

(4) Conservation purpose defined.

(A) In general. For purposes of this subsection, the term "conservation purpose" means--

(i) the preservation of land areas for outdoor recreation by, or the education of, the general public,

(ii) the protection of a relatively natural habitat of fish, wildlife, or plants, or similar ecosystem,

(iii) the preservation of open space (including farmland and forest land) where such preservation is--

(I) for the scenic enjoyment of the general public, or

(II) pursuant to a clearly delineated Federal, State, or local governmental conservation policy,

and will yield a significant public benefit, or

(iv) the preservation of an historically important land area or a certified historic structure. 
(B) Special rules with respect to buildings in registered historic districts. In the case of any contribution of a qualified real property interest which is a restriction with respect to the exterior of a building described in subparagraph (C)(ii), such contribution shall not be considered to be exclusively for conservation purposes unless--

(i) such interest--

(I) includes a restriction which preserves the entire exterior of the building (including the front, sides, rear, and height of the building), and

(II) prohibits any change in the exterior of the building which is inconsistent with the historical character of such exterior,

(ii) the donor and donee enter into a written agreement certifying, under penalty of perjury, that the donee--

(I) is a qualified organization (as defined in paragraph (3)) with a purpose of environmental protection, land conservation, open space preservation, or historic preservation, and (II) has the resources to manage and enforce the restriction and a commitment to do so, and

(iii) in the case of any contribution made in a taxable year beginning after the date of the enactment of this subparagraph [Aug. 17, 2006], the taxpayer includes with the taxpayer's return for the taxable year of the contribution--

(I) a qualified appraisal (within the meaning of subsection (f)(11)(E)) of the qualified property interest,

(II) photographs of the entire exterior of the building, and (III) a description of all restrictions on the development of the building.

(C) Certified historic structure. For purposes of subparagraph (A)(iv), the term "certified historic structure" means--

(i) any building, structure, or land area which is listed in the National Register, or

(ii) any building which is located in a registered historic district (as defined in section 47 (C)(3)(B) and is certified by the Secretary of the Interior to the Secretary as being of historic significance to the district.

A building, structure, or land area satisfies the preceding sentence if it satisfies such sentence either at the time of the transfer or on the due date (including extensions) for filing the transferor's return under this chapter for the taxable year in which the transfer is made. 
(5) Exclusively for conservation purposes. For purposes of this subsection-(A) Conservation purpose must be protected. A contribution shall not be treated as exclusively for conservation purposes unless the conservation purpose is protected in perpetuity.

(B) No surface mining permitted.

(i) In general. Except as provided in clause (ii), in the case of a contribution of any interest where there is a retention of a qualified mineral interest, subparagraph (A) shall not be treated as met if at any time there may be extraction or removal of minerals by any surface mining method.

(ii) Special rule. With respect to any contribution of property in which the ownership of the surface estate and mineral interests has been and remains separated, subparagraph (A) shall be treated as met if the probability of surface mining occurring on such property is so remote as to be negligible.

(6) Qualified mineral interest. For purposes of this subsection, the term "qualified mineral interest" means--

(A) subsurface oil, gas, or other minerals, and

(B) the right to access to such minerals 


\section{Appendix B}

\section{Treasury Regulation §1.170A-14}

\section{$\S$ 1.170A-14 Qualified Conservation Contributions.}

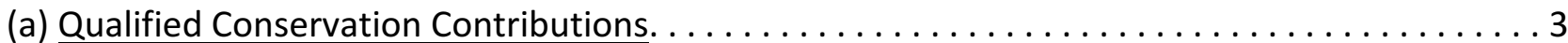

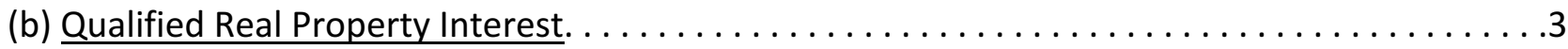

(1) Entire interest of donor other than qualified mineral interest

(2) Perpetual conservation restriction

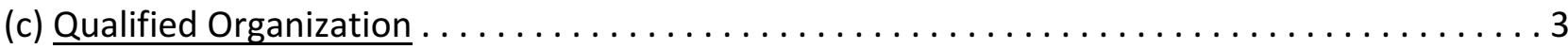

(1) Eligible donee

(2) Transfers by donee

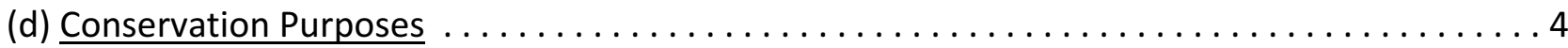

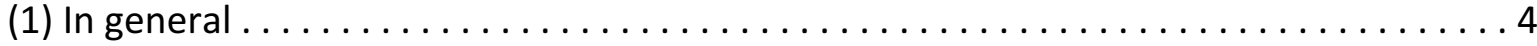

(2) Recreation or education $\ldots \ldots \ldots \ldots \ldots \ldots \ldots \ldots \ldots \ldots \ldots \ldots \ldots \ldots \ldots$

(i) In general

(ii) Access

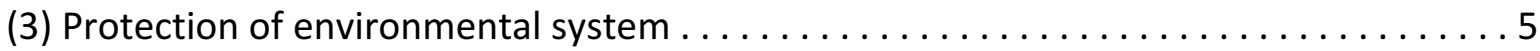

(i) In general

(ii) Significant habitat or ecosystem

(iii) Access

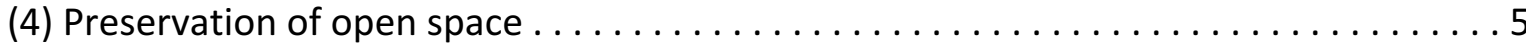

(i) In general

(ii) Scenic enjoyment
(A) Factors
(B) Access

(iii) Governmental conservation policy
(A) In general
(B) Effect of acceptance by governmental agency
(C) Access

(iv) Significant public benefit
(A) Factors
(B) Illustrations

(v) Limitation

(vi) Relationship of requirements

(A) Clearly delineated governmental policy and significant public benefit

(B) Scenic enjoyment and significant public benefit

(C) Donations may satisfy more than one test

(5) Historic preservation.

(i) In general

(ii) Historically important land area

(iii) Certified historic structure 
(iv) Access

(v) Examples

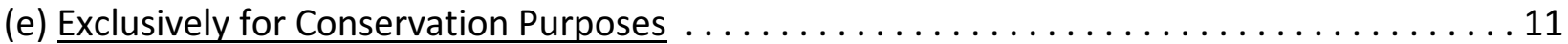

(1) In general

(2) Inconsistent use

(3) Inconsistent use permitted

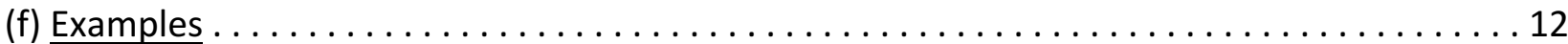

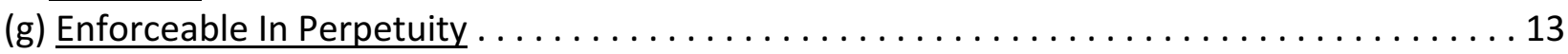

(1) In general

(2) Protection of a conservation purpose in case of donation of property subject to a mortgage

(3) Remote future event

(4) Retention of qualified mineral interest

(i) In general

(ii) Exception for qualified conservation contributions after July 1984

(iii) Examples

(5) Protection of conservation purpose where taxpayer reserves certain rights

(i) Documentation

(ii) Donee's right to inspection and legal remedies

(6) Extinguishment

(i) In general

(ii) Proceeds

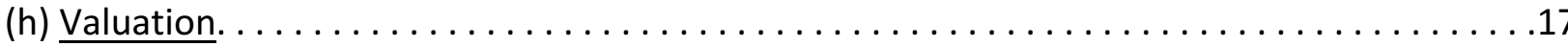

(1) Entire interest of donor other than qualified mineral interest

(2) Remainder interest in real property

(3) Perpetual conservation restriction

(i) In general

(ii) Fair market value of property before and after restriction

(iii) Allocation of basis

(4) Examples

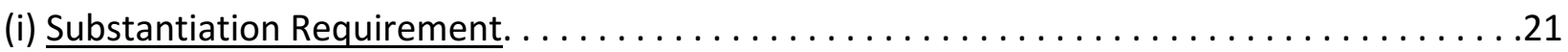

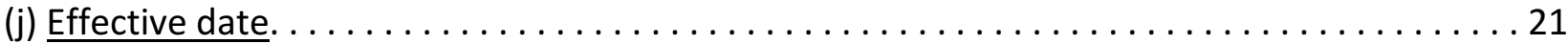




\section{§ 1.170A-14 Qualified conservation contributions.}

(a) Qualified conservation contributions. A deduction under section 170 is generally not allowed for a charitable contribution of any interest in property that consists of less than the donor's entire interest in the property other than certain transfers in trust (see $\S 1.170 \mathrm{~A}-6$ relating to charitable contributions in trust and $\S 1.170 \mathrm{~A}-7$ relating to contributions not in trust of partial interests in property). However, a deduction may be allowed under section 170(f)(3)(B)(iii) for the value of a qualified conservation contribution if the requirements of this section are met. A qualified conservation contribution is the contribution of a qualified real property interest to a qualified organization exclusively for conservation purposes. To be eligible for a deduction under this section, the conservation purpose must be protected in perpetuity.

(b) Qualified real property interest -- (1) Entire interest of donor other than qualified mineral interest. (i) The entire interest of the donor other than a qualified mineral interest is a qualified real property interest. A qualified mineral interest is the donor's interest in subsurface oil, gas, or other minerals and the right of access to such minerals.

(ii) A real property interest shall not be treated as an entire interest other than a qualified mineral interest by reason of section $170(h)(2)(A)$ and this paragraph $(b)(1)$ if the property in which the donor's interest exists was divided prior to the contribution in order to enable the donor to retain control of more than a qualified mineral interest or to reduce the real property interest donated. See Treasury regulations $\S 1.170 \mathrm{~A}-7(\mathrm{a})(2)(\mathrm{i})$. An entire interest in real property may consist of an undivided interest in the property. But see section 170(h)(5)(A) and the regulations thereunder (relating to the requirement that the conservation purpose which is the subject of the donation must be protected in perpetuity). Minor interests, such as rights-of-way, that will not interfere with the conservation purposes of the donation, may be transferred prior to the conservation contribution without affecting the treatment of a property interest as a qualified real property interest under this paragraph (b)(1).

(2) Perpetual conservation restriction. A "perpetual conservation restriction" is a qualified real property interest. A "perpetual conservation restriction" is a restriction granted in perpetuity on the use which may be made of real property -- including, an easement or other interest in real property that under state law has attributes similar to an easement (e.g., a restrictive covenant or equitable servitude). For purposes of this section, the terms easement, conservation restriction, and perpetual conservation restriction have the same meaning. The definition of perpetual conservation restriction under this paragraph $(b)(2)$ is not intended to preclude the deductibility of a donation of affirmative rights to use a land or water area under $\S 1.170 \mathrm{~A}-13(\mathrm{~d})(2)$. Any rights reserved by the donor in the donation of a perpetual conservation restriction must conform to the requirements of this section. See e.g., paragraph (d)(4)(ii), (d)(5)(i), (e)(3), and (g)(4) of this section.

(c) Qualified organization -- (1) Eligible donee. To be considered an eligible donee under this section, an organization must be a qualified organization, have a commitment to protect the conservation purposes of the donation, and have the resources to enforce the restrictions. A conservation group organized or operated primarily or substantially for one of the conservation purposes specified in section $170(\mathrm{~h})(4)(A)$ will be considered to have the commitment required by the preceding sentence. A qualified organization need not set aside funds to enforce the 
restrictions that are the subject of the contribution. For purposes of this section, the term qualified organization means:

(i) A governmental unit described in section $170(b)(1)(A)(v)$;

(ii) An organization described in section 170(b)(1)(A)(vi);

(iii) A charitable organization described in section 501 (c)(3) that meets the public support test of section $509(a)(2)$;

(iv) A charitable organization described in section 501(c)(3) that meets the requirements of section 509(a)(3) and is controlled by an organization described in paragraphs (c)(1) (i), (ii), or (iii) of this section.

(2) Transfers by donee. A deduction shall be allowed for a contribution under this section only if in the instrument of conveyance the donor prohibits the donee from subsequently transferring the easement (or, in the case of a remainder interest or the reservation of a qualified mineral interest, the property), whether or not for consideration, unless the donee organization, as a condition of the subsequent transfer, requires that the conservation purposes which the contribution was originally intended to advance continue to be carried out. Moreover, subsequent transfers must be restricted to organizations qualifying, at the time of the subsequent transfer, as an eligible donee under paragraph (c)(1) of this section. When a later unexpected change in the conditions surrounding the property that is the subject of a donation under paragraph (b)(1), (2), or (3) of this section makes impossible or impractical the continued use of the property for conservation purposes, the requirement of this paragraph will be met if the property is sold or exchanged and any proceeds are used by the donee organization in a manner consistent with the conservation purposes of the original contribution. In the case of a donation under paragraph (b)(3) of this section to which the preceding sentence applies, see also paragraph (g)(5)(ii) of this section.

(d) Conservation purposes -- (1) In general. For purposes of section $170(\mathrm{~h})$ and this section, the term conservation purposes means --

(i) The preservation of land areas for outdoor recreation by, or the education of, the general public, within the meaning of paragraph $(d)(2)$ of this section,

(ii) The protection of a relatively natural habitat of fish, wildlife, or plants, or similar ecosystem, within the meaning of paragraph $(d)(3)$ of this section,

(iii) The preservation of certain open space (including farmland and forest land) within the meaning of paragraph $(d)(4)$ of this section, or

(iv) The preservation of a historically important land area or a certified historic structure, within the meaning of paragraph (d)(5) of this section.

(2) Recreation or education -- (i) In general. The donation of a qualified real property interest to preserve land areas for the outdoor recreation of the general public or for the education of the general public will meet the conservation purposes test of this section. Thus, conservation purposes would include, for example, the preservation of a water area for the use of the public for boating or fishing, or a nature or hiking trail for the use of the public. 
(ii) Access. The preservation of land areas for recreation or education will not meet the test of this section unless the recreation or education is for the substantial and regular use of the general public.

(3) Protection of environmental system -- (i) In general. The donation of a qualified real property interest to protect a significant relatively natural habitat in which a fish, wildlife, or plant community, or similar ecosystem normally lives will meet the conservation purposes test of this section. The fact that the habitat or environment has been altered to some extent by human activity will not result in a deduction being denied under this section if the fish, wildlife, or plants continue to exist there in a relatively natural state. For example, the preservation of a lake formed by a man-made dam or a salt pond formed by a man-made dike would meet the conservation purposes test if the lake or pond were a nature feeding area for a wildlife community that included rare, endangered, or threatened native species.

(ii) Significant habitat or ecosystem. Significant habitats and ecosystems include, but are not limited to, habitats for rare, endangered, or threatened species of animal, fish, or plants; natural areas that represent high quality examples of a terrestrial community or aquatic community, such as islands that are undeveloped or not intensely developed where the coastal ecosystem is relatively intact; and natural areas which are included in, or which contribute to, the ecological viability of a local, state, or national park, nature preserve, wildlife refuge, wilderness area, or other similar conservation area.

(iii) Access. Limitations on public access to property that is the subject of a donation under this paragraph (d)(3) shall not render the donation nondeductible. For example, a restriction on all public access to the habitat of a threatened native animal species protected by a donation under this paragraph (d)(3) would not cause the donation to be nondeductible.

(4) Preservation of open space -- (i) In general. The donation of a qualified real property interest to preserve open space (including farmland and forest land) will meet the conservation purposes test of this section if such preservation is --

(A) Pursuant to a clearly delineated Federal, state, or local governmental conservation policy and will yield a significant public benefit, or

(B) For the scenic enjoyment of the general public and will yield a significant public benefit.

An open space easement donated on or after December 18, 1980, must meet the requirements of section $170(\mathrm{~h})$ in order to be deductible.

(ii) Scenic enjoyment -- (A) Factors. A contribution made for the preservation of open space may be for the scenic enjoyment of the general public. Preservation of land may be for the scenic enjoyment of the general public if development of the property would impair the scenic character of the local rural or urban landscape or would interfere with a scenic panorama that can be enjoyed from a park, nature preserve, road, waterbody, trail, or historic structure or land area, and such area or transportation way is open to, or utilized by, the public. "Scenic enjoyment" will be evaluated by considering all pertinent facts and circumstances germane to the contribution. Regional variations in topography, geology, biology, and cultural and economic conditions require flexibility in the application of this test, but do not lessen the burden on the taxpayer to 
demonstrate the scenic characteristics of a donation under this paragraph. The application of a particular objective factor to help define a view as "scenic" in one setting may in fact be entirely inappropriate in another setting. Among the factors to be considered are:

(1) The compatibility of the land use with other land in the vicinity;

(2) The degree of contrast and variety provided by the visual scene;

(3) The openness of the land (which would be a more significant factor in an urban or densely populated setting or in a heavily wooded area);

(4) Relief from urban closeness;

(5) The harmonious variety of shapes and textures;

(6) The degree to which the land use maintains the scale and character of the urban landscape to preserve open space, visual enjoyment, and sunlight for the surrounding area;

(7) The consistency of the proposed scenic view with a methodical state scenic identification program, such as a state landscape inventory; and

(8) The consistency of the proposed scenic view with a regional or local landscape inventory made pursuant to a sufficiently rigorous review process, especially if the donation is endorsed by an appropriate state or local governmental agency.

(B) Access. To satisfy the requirement of scenic enjoyment by the general public, visual (rather than physical) access to or across the property by the general public is sufficient. Under the terms of an open space easement on scenic property, the entire property need not be visible to the public for a donation to qualify under this section, although the public benefit from the donation may be insufficient to qualify for a deduction if only a small portion of the property is visible to the public.

(iii) Governmental conservation policy -- (A) In general. The requirement that the preservation of open space be pursuant to a clearly delineated Federal, state, or local governmental policy is intended to protect the types of property identified by representatives of the general public as worthy of preservation or conservation. A general declaration of conservation goals by a single official or legislative body is not sufficient. However, a governmental conservation policy need not be a certification program that identifies particular lots or small parcels of individually owned property. This requirement will be met by donations that further a specific, identified conservation project, such as the preservation of land within a state or local landmark district that is locally recognized as being significant to that district; the preservation of a wild or scenic river, the preservation of farmland pursuant to a state program for flood prevention and control; or the protection of the scenic, ecological, or historic character of land that is contiguous to, or an integral part of, the surroundings of existing recreation or conservation sites. For example, the donation of a perpetual conservation restriction to a qualified organization pursuant to a formal resolution or certification by a local governmental agency established under state law specifically identifying the subject property as worthy of protection for conservation purposes will meet the requirement of this paragraph. A program need not be funded to satisfy this requirement, but the program must involve a significant commitment by the government with respect to the 
conservation project. For example, a governmental program according preferential tax assessment or preferential zoning for certain property deemed worthy of protection for conservation purposes would constitute a significant commitment by the government.

(B) Effect of acceptance by governmental agency. Acceptance of an easement by an agency of the Federal Government or by an agency of a state or local government (or by a commission, authority, or similar body duly constituted by the state or local government and acting on behalf of the state or local government) tends to establish the requisite clearly delineated governmental policy, although such acceptance, without more, is not sufficient. The more rigorous the review process by the governmental agency, the more the acceptance of the easement tends to establish the requisite clearly delineated governmental policy. For example, in a state where the legislature has established an Environmental Trust to accept gifts to the state which meet certain conservation purposes and to submit the gifts to a review that requires the approval of the state's highest officials, acceptance of a gift by the Trust tends to establish the requisite clearly delineated governmental policy. However, if the Trust merely accepts such gifts without a review process, the requisite clearly delineated governmental policy is not established.

(C) Access. A limitation on public access to property subject to a donation under this paragraph (d)(4)(iii) shall not render the deduction nondeductible unless the conservation purpose of the donation would be undermined or frustrated without public access. For example, a donation pursuant to a governmental policy to protect the scenic character of land near a river requires visual access to the same extent as would a donation under paragraph (d)(4)(ii) of this section.

(iv) Significant public benefit -- (A) Factors. All contributions made for the preservation of open space must yield a significant public benefit. Public benefit will be evaluated by considering all pertinent facts and circumstances germane to the contribution. Factors germane to the evaluation of public benefit from one contribution may be irrelevant in determining public benefit from another contribution. No single factor will necessarily be determinative. Among the factors to be considered are:

(1) The uniqueness of the property to the area;

(2) The intensity of land development in the vicinity of the property (both existing development and foreseeable trends of development);

(3) The consistency of the proposed open space use with public programs (whether Federal, state or local) for conservation in the region, including programs for outdoor recreation, irrigation or water supply protection, water quality maintenance or enhancement, flood prevention and control, erosion control, shoreline protection, and protection of land areas included in, or related to, a government approved master plan or land management area;

(4) The consistency of the proposed open space use with existing private conservation programs in the area, as evidenced by other land, protected by easement or fee ownership by organizations referred to in $\S 1.170 \mathrm{~A}-14(\mathrm{c})(1)$, in close proximity to the property;

(5) The likelihood that development of the property would lead to or contribute to degradation of the scenic, natural, or historic character of the area; 
(6) The opportunity for the general public to use the property or to appreciate its scenic values;

(7) The importance of the property in preserving a local or regional landscape or resource that attracts tourism or commerce to the area;

(8) The likelihood that the donee will acquire equally desirable and valuable substitute property or property rights;

(9) The cost to the donee of enforcing the terms of the conservation restriction;

(10) The population density in the area of the property; and

(11) The consistency of the proposed open space use with a legislatively mandated program identifying particular parcels of land for future protection.

(B) Illustrations. The preservation of an ordinary tract of land would not in and of itself yield a significant public benefit, but the preservation of ordinary land areas in conjunction with other factors that demonstrate significant public benefit or the preservation of a unique land area for public employment would yield a significant public benefit. For example, the preservation of a vacant downtown lot would not by itself yield a significant public benefit, but the preservation of the downtown lot as a public garden would, absent countervailing factors, yield a significant public benefit. The following are other examples of contributions which would, absent countervailing factors, yield a significant public benefit: The preservation of farmland pursuant to a state program for flood prevention and control; the preservation of a unique natural land formation for the enjoyment of the general public; the preservation of woodland along a public highway pursuant to a government program to preserve the appearance of the area so as to maintain the scenic view from the highway; and the preservation of a stretch of undeveloped property located between a public highway and the ocean in order to maintain the scenic ocean view from the highway.

(v) Limitation. A deduction will not be allowed for the preservation of open space under section $170(\mathrm{~h})(4)(\mathrm{A})(\mathrm{iii})$, if the terms of the easement permit a degree of intrusion or future development that would interfere with the essential scenic quality of the land or with the governmental conservation policy that is being furthered by the donation. See $\S 1.170 A-14(e)(2)$ for rules relating to inconsistent use.

(vi) Relationship of requirements -- (A) Clearly delineated governmental policy and significant public benefit. Although the requirements of "clearly delineated governmental policy" and "significant public benefit" must be met independently, for purposes of this section the two requirements may also be related. The more specific the governmental policy with respect to the particular site to be protected, the more likely the governmental decision, by itself, will tend to establish the significant public benefit associated with the donation. For example, while a statute in State $X$ permitting preferential assessment for farmland is, by definition, governmental policy, it is distinguishable from a state statute, accompanied by appropriations, naming the $\mathrm{X}$ River as a valuable resource and articulating the legislative policy that the $X$ River and the relatively natural quality of its surrounding be protected. On these facts, an open space easement on farmland in State $X$ would have to demonstrate additional factors to establish "significant public benefit." The specificity of the legislative mandate to protect the $X$ River, however, would by itself tend to 
establish the significant public benefit associated with an open space easement on land fronting the $\mathrm{X}$ River.

(B) Scenic enjoyment and significant public benefit. With respect to the relationship between the requirements of "scenic enjoyment" and "significant public benefit," since the degrees of scenic enjoyment offered by a variety of open space easements are subjective and not as easily delineated as are increasingly specific levels of governmental policy, the significant public benefit of preserving a scenic view must be independently established in all cases.

(C) Donations may satisfy more than one test. In some cases, open space easements may be both for scenic enjoyment and pursuant to a clearly delineated governmental policy. For example, the preservation of a particular scenic view identified as part of a scenic landscape inventory by a rigorous governmental review process will meet the tests of both paragraphs $(d)(4)(i)(A)$ and (d)(4)(i)(B) of this section.

(5) Historic preservation -- (i) In general. The donation of a qualified real property interest to preserve an historically important land area or a certified historic structure will meet the conservation purposes test of this section. When restrictions to preserve a building or land area within a registered historic district permit future development on the site, a deduction will be allowed under this section only if the terms of the restrictions require that such development conform with appropriate local, state, or Federal standards for construction or rehabilitation within the district. See also, $\S 1.170 \mathrm{~A}-14(\mathrm{~h})(3)(\mathrm{ii})$.

(ii) Historically important land area. The term historically important land area includes:

(A) An independently significant land area including any related historic resources (for example, an archaeological site or a Civil War battlefield with related monuments, bridges, cannons, or houses) that meets the National Register Criteria for Evaluation in 36 CFR 60.4 (Pub. L. 89-665, 80 Stat. 915);

(B) Any land area within a registered historic district including any buildings on the land area that can reasonably be considered as contributing to the significance of the district; and

(C) Any land area (including related historic resources) adjacent to a property listed individually in the National Register of Historic Places (but not within a registered historic district) in a case where the physical or environmental features of the land area contribute to the historic or cultural integrity of the property.

(iii) Certified historic structure. The term certified historic structure, for purposes of this section, means any building, structure or land area which is --

(A) Listed in the National Register, or

(B) Located in a registered historic district (as defined in section 48(g)(3)(B)) and is certified by the Secretary of the Interior (pursuant to 36 CFR 67.4) to the Secretary of the Treasury as being of historic significance to the district.

A structure for purposes of this section means any structure, whether or not it is depreciable. Accordingly easements on private residences may qualify under this section. In addition, a structure would be considered to be a certified historic structure if it were certified either at the 
time the transfer was made or at the due date (including extensions) for filing the donor's return for the taxable year in which the contribution was made.

(iv) Access. (A) In order for a conservation contribution described in section $170(\mathrm{~h})(4)(\mathrm{A})(\mathrm{iv})$ and this paragraph $(\mathrm{d})(5)$ to be deductible, some visual public access to the donated property is required. In the case of an historically important land area, the entire property need not be visible to the public for a donation to qualify under this section. However, the public benefit from the donation may be insufficient to qualify for a deduction if only a small portion of the property is so visible. Where the historic land area or certified historic structure which is the subject of the donation is not visible from a public way (e.g., the structure is hidden from view by a wall or shrubbery, the structure is too far from the public way, or interior characteristics and features of the structure are the subject of the easement), the terms of the easement must be such that the general public is given the opportunity on a regular basis to view the characteristics and features of the property which are preserved by the easement to the extent consistent with the nature and condition of the property.

(B) Factors to be considered in determining the type and amount of public access required under paragraph (d)(5)(iv)(A) of this section include the historical significance of the donated property, the nature of the features that are the subject of the easement, the remoteness or accessibility of the site of the donated property, the possibility of physical hazards to the public visiting the property (for example, an unoccupied structure in a dilapidated condition), the extent to which public access would be an unreasonable intrusion on any privacy interests of individuals living on the property, the degree to which public access would impair the preservation interests which are the subject of the donation, and the availability of opportunities for the public to view the property by means other than visits to the site.

(C) The amount of access afforded the public by the donation of an easement shall be determined with reference to the amount of access permitted by the terms of the easement which are established by the donor, rather than the amount of access actually provided by the donee organization. However, if the donor is aware of any facts indicating that the amount of access that the donee organization will provide is significantly less than the amount of access permitted under the terms of the easement, then the amount of access afforded the public shall be determined with reference to this lesser amount.

(v) Examples. The provisions of paragraph (d)(5)(iv) of this section may be illustrated by the following examples:

Example 1. A and his family live in a house in a certified historic district in the State of X. The entire house, including its interior, has architectural features representing classic Victorian period architecture. A donates an exterior and interior easement on the property to a qualified organization but continues to live in the house with his family. A's house is surrounded by a high stone wall which obscures the public's view of it from the street. Pursuant to the terms of the easement, the house may be opened to the public from 10:00 a.m. to 4:00 p.m. on one Sunday in May and one Sunday in November each year for house and garden tours. These tours are to be under the supervision of the donee and open to members of the general public upon payment of a small fee. In addition, under the terms of the easement, the donee organization is given the right 
to photograph the interior and exterior of the house and distribute such photographs to magazines, newsletters, or other publicly available publications. The terms of the easement also permit persons affiliated with educational organizations, professional architectural associations, and historical societies to make an appointment through the donee organization to study the property. The donor is not aware of any facts indicating that the public access to be provided by the donee organization will be significantly less than that permitted by the terms of the easement. The 2 opportunities for public visits per year, when combined with the ability of the general public to view the architectural characteristics and features that are the subject of the easement through photographs, the opportunity for scholarly study of the property, and the fact that the house is used as an occupied residence, will enable the donation to satisfy the requirement of public access.

Example 2. B owns an unoccupied farmhouse built in the 1840's and located on a property that is adjacent to a Civil War battlefield. During the Civil War the farmhouse was used as quarters for Union troops. The battlefield is visited year round by the general public. The condition of the farmhouse is such that the safety of visitors will not be jeopardized and opening it to the public will not result in significant deterioration. The farmhouse is not visible from the battlefield or any public way. It is accessible only by way of a private road owned by B. B donates a conservation easement on the farmhouse to a qualified organization. The terms of the easement provide that the donee organization may open the property (via B's road) to the general public on four weekends each year from 8:30 a.m. to 4:00 p.m. The donation does not meet the public access requirement because the farmhouse is safe, unoccupied, and easily accessible to the general public who have come to the site to visit Civil War historic land areas (and related resources), but will only be open to the public on four weekends each year. However, the donation would meet the public access requirement if the terms of the easement permitted the donee organization to open the property to the public every other weekend during the year and the donor is not aware of any facts indicating that the donee organization will provide significantly less access than that permitted.

(e) Exclusively for conservation purposes -- (1) In general. To meet the requirements of this section, a donation must be exclusively for conservation purposes. See paragraphs (c)(1) and (g)(1) through (g)(6)(ii) of this section. A deduction will not be denied under this section when incidental benefit inures to the donor merely as a result of conservation restrictions limiting the uses to which the donor's property may be put.

(2) Inconsistent use. Except as provided in paragraph (e)(4) of this section, a deduction will not be allowed if the contribution would accomplish one of the enumerated conservation purposes but would permit destruction of other significant conservation interests. For example, the preservation of farmland pursuant to a State program for flood prevention and control would not qualify under paragraph $(d)(4)$ of this section if under the terms of the contribution a significant naturally occurring ecosystem could be injured or destroyed by the use of pesticides in the operation of the farm. However, this requirement is not intended to prohibit uses of the property, such as selective timber harvesting or selective farming if, under the circumstances, those uses do not impair significant conservation interests. 
(3) Inconsistent use permitted. A use that is destructive of conservation interests will be permitted only if such use is necessary for the protection of the conservation interests that are the subject of the contribution. For example, a deduction for the donation of an easement to preserve an archaeological site that is listed on the National Register of Historic Places will not be disallowed if site excavation consistent with sound archaeological practices may impair a scenic view of which the land is a part. A donor may continue a pre-existing use of the property that does not conflict with the conservation purposes of the gift.

(f) Examples. The provisions of this section relating to conservation purposes may be illustrated by the following examples.

Example 1. State $\mathrm{S}$ contains many large tract forests that are desirable recreation and scenic areas for the general public. The forests' scenic values attract millions of people to the State. However, due to the increasing intensity of land development in State $S$, the continued existence of forestland parcels greater than 45 acres is threatened. J grants a perpetual easement on a 100acre parcel of forestland that is part of one of the State's scenic areas to a qualifying organization. The easement imposes restrictions on the use of the parcel for the purpose of maintaining its scenic values. The restrictions include a requirement that the parcel be maintained forever as open space devoted exclusively to conservation purposes and wildlife protection, and that there be no commercial, industrial, residential, or other development use of such parcel. The law of State $S$ recognizes a limited public right to enter private land, particularly for recreational pursuits, unless such land is posted or the landowner objects. The easement specifically restricts the landowner from posting the parcel, or from objecting, thereby maintaining public access to the parcel according to the custom of the State. J's parcel provides the opportunity for the public to enjoy the use of the property and appreciate its scenic values. Accordingly, J's donation qualifies for a deduction under this section.

Example 2. A qualified conservation organization owns Greenacre in fee as a nature preserve. Greenacre contains a high quality example of a tall grass prairie ecosystem. Farmacre, an operating farm, adjoins Greenacre and is a compatible buffer to the nature preserve. Conversion of Farmacre to a more intense use, such as a housing development, would adversely affect the continued use of Greenacre as a nature preserve because of human traffic generated by the development. The owner of Farmacre donates an easement preventing any future development on Farmacre to the qualified conservation organization for conservation purposes. Normal agricultural uses will be allowed on Farmacre. Accordingly, the donation qualifies for a deduction under this section.

Example 3. H owns Greenacre, a 900-acre parcel of woodland, rolling pasture, and orchards on the crest of a mountain. All of Greenacre is clearly visible from a nearby national park. Because of the strict enforcement of an applicable zoning plan, the highest and best use of Greenacre is as a subdivision of 40 -acre tracts. $\mathrm{H}$ wishes to donate a scenic easement on Greenacre to a qualifying conservation organization, but $\mathrm{H}$ would like to reserve the right to subdivide Greenacre into 90acre parcels with no more than one single-family home allowable on each parcel. Random building on the property, even as little as one home for each 90 acres, would destroy the scenic character of the view. Accordingly, no deduction would be allowable under this section. 
Example 4. Assume the same facts as in example (3), except that not all of Greenacre is visible from the park and the deed of easement allows for limited cluster development of no more than five nine-acre clusters (with four houses on each cluster) located in areas generally not visible from the national park and subject to site and building plan approval by the donee organization in order to preserve the scenic view from the park. The donor and the donee have already identified sites where limited cluster development would not be visible from the park or would not impair the view. Owners of homes in the clusters will not have any rights with respect to the surrounding Greenacre property that are not also available to the general public. Accordingly, the donation qualifies for a deduction under this section.

Example 5. In order to protect State S's declining open space that is suited for agricultural use from increasing development pressure that has led to a marked decline in such open space, the Legislature of State S passed a statute authorizing the purchase of "agricultural land development rights" on open acreage. Agricultural land development rights allow the State to place agricultural preservation restrictions on land designated as worthy of protection in order to preserve open space and farm resources. Agricultural preservation restrictions prohibit or limit construction or placement of buildings except those used for agricultural purposes or dwellings used for family living by the farmer and his family and employees; removal of mineral substances in any manner that adversely affects the land's agricultural potential; or other uses detrimental to retention of the land for agricultural use. Money has been appropriated for this program and some landowners have in fact sold their "agricultural land development rights" to State S. K owns and operates a small dairy farm in State $\mathrm{S}$ located in an area designated by the Legislature as worthy of protection. $\mathrm{K}$ desires to preserve his farm for agricultural purposes in perpetuity. Rather than selling the development rights to State $\mathrm{S}, \mathrm{K}$ grants to a qualified organization an agricultural preservation restriction on his property in the form of a conservation easement. $K$ reserves to himself, his heirs and assigns the right to manage the farm consistent with sound agricultural and management practices. The preservation of $\mathrm{K}$ 's land is pursuant to a clearly delineated governmental policy of preserving open space available for agricultural use, and will yield a significant public benefit by preserving open space against increasing development pressures.

(g) Enforceable in perpetuity -- (1) In general. In the case of any donation under this section, any interest in the property retained by the donor (and the donor's successors in interest) must be subject to legally enforceable restrictions (for example, by recordation in the land records of the jurisdiction in which the property is located) that will prevent uses of the retained interest inconsistent with the conservation purposes of the donation. In the case of a contribution of a remainder interest, the contribution will not qualify if the tenants, whether they are tenants for life or a term of years, can use the property in a manner that diminishes the conservation values which are intended to be protected by the contribution.

(2) Protection of a conservation purpose in case of donation of property subject to a mortgage. In the case of conservation contributions made after February 13, 1986, no deduction will be permitted under this section for an interest in property which is subject to a mortgage unless the mortgagee subordinates its rights in the property to the right of the qualified organization to enforce the conservation purposes of the gift in perpetuity. For conservation contributions made prior to February 14, 1986, the requirement of section $170(h)(5)(A)$ is satisfied 
in the case of mortgaged property (with respect to which the mortgagee has not subordinated its rights) only if the donor can demonstrate that the conservation purpose is protected in perpetuity without subordination of the mortgagee's rights.

(3) Remote future event. A deduction shall not be disallowed under section 170(f)(3)(B)(iii) and this section merely because the interest which passes to, or is vested in, the donee organization may be defeated by the performance of some act or the happening of some event, if on the date of the gift it appears that the possibility that such act or event will occur is so remote as to be negligible. See paragraph (e) of $\S 1.170 \mathrm{~A}-1$. For example, a state's statutory requirement that use restrictions must be rerecorded every 30 years to remain enforceable shall not, by itself, render an easement nonperpetual.

(4) Retention of qualified mineral interest -- (i) In general. Except as otherwise provided in paragraph (g)(4)(ii) of this section, the requirements of this section are not met and no deduction shall be allowed in the case of a contribution of any interest when there is a retention by any person of a qualified mineral interest (as defined in paragraph (b)(1)(i) of this section) if at any time there may be extractions or removal of minerals by any surface mining method. Moreover, in the case of a qualified mineral interest gift, the requirement that the conservation purposes be protected in perpetuity is not satisfied if any method of mining that is inconsistent with the particular conservation purposes of a contribution is permitted at any time. See also $\S 1.170 \mathrm{~A}-$ 14(e)(2). However, a deduction under this section will not be denied in the case of certain methods of mining that may have limited, localized impact on the real property but that are not irremediably destructive of significant conservation interests. For example, a deduction will not be denied in a case where production facilities are concealed or compatible with existing topography and landscape and when surface alteration is to be restored to its original state.

(ii) Exception for qualified conservation contributions after July 1984. (A) A contribution made after July 18, 1984, of a qualified real property interest described in section 170(h)(2)(A) shall not be disqualified under the first sentence of paragraph $(\mathrm{g})(4)(\mathrm{i})$ of this section if the following requirements are satisfied.

(1) The ownership of the surface estate and mineral interest were separated before June 13, 1976 , and remain so separated up to and including the time of the contribution.

(2) The present owner of the mineral interest is not a person whose relationship to the owner of the surface estate is described at the time of the contribution in section $267(b)$ or section 707(b), and

(3) The probability of extraction or removal of minerals by any surface mining method is so remote as to be negligible.

Whether the probability of extraction or removal of minerals by surface mining is so remote as to be negligible is a question of fact and is to be made on a case by case basis. Relevant factors to be considered in determining if the probability of extraction or removal of minerals by surface mining is so remote as to be negligible include: Geological, geophysical or economic data showing the absence of mineral reserves on the property, or the lack of commercial feasibility at the time of the contribution of surface mining the mineral interest. 
(B) If the ownership of the surface estate and mineral interest first became separated after June 12, 1976, no deduction is permitted for a contribution under this section unless surface mining on the property is completely prohibited.

(iii) Examples. The provisions of paragraph (g)(4)(i) and (ii) of this section may be illustrated by the following examples:

Example 1. K owns 5,000 acres of bottomland hardwood property along a major watershed system in the southern part of the United States. Agencies within the Department of the Interior have determined that southern bottomland hardwoods are a rapidly diminishing resource and a critical ecosystem in the south because of the intense pressure to cut the trees and convert the land to agricultural use. These agencies have further determined (and have indicated in correspondence with $\mathrm{K}$ ) that bottomland hardwoods provide a superb habitat for numerous species and play an important role in controlling floods and purifying rivers. $\mathrm{K}$ donates to a qualified organization his entire interest in this property other than his interest in the gas and oil deposits that have been identified under K's property. K covenants and can ensure that, although drilling for gas and oil on the property may have some temporary localized impact on the real property, the drilling will not interfere with the overall conservation purpose of the gift, which is to protect the unique bottomland hardwood ecosystem. Accordingly, the donation qualifies for a deduction under this section.

Example 2. Assume the same facts as in example (1), except that in $1979, \mathrm{~K}$ sells the mineral interest to A, an unrelated person, in an arm's-length transaction, subject to a recorded prohibition on the removal of any minerals by any surface mining method and a recorded prohibition against any mining technique that will harm the bottomland hardwood ecosystem. After the sale to $\mathrm{A}, \mathrm{K}$ donates a qualified real property interest to a qualified organization to protect the bottomland hardwood ecosystem. Since at the time of the transfer, surface mining and any mining technique that will harm the bottomland hardwood ecosystem are completely prohibited, the donation qualifies for a deduction under this section.

(5) Protection of conservation purpose where taxpayer reserves certain rights. (i) Documentation. In the case of a donation made after February 13, 1986, of any qualified real property interest when the donor reserves rights the exercise of which may impair the conservation interests associated with the property, for a deduction to be allowable under this section the donor must make available to the donee, prior to the time the donation is made, documentation sufficient to establish the condition of the property at the time of the gift. Such documentation is designed to protect the conservation interests associated with the property, which although protected in perpetuity by the easement, could be adversely affected by the exercise of the reserved rights. Such documentation may include:

(A) The appropriate survey maps from the United States Geological Survey, showing the property line and other contiguous or nearby protected areas;

(B) A map of the area drawn to scale showing all existing man-made improvements or incursions (such as roads, buildings, fences, or gravel pits), vegetation and identification of flora and fauna (including, for example, rare species locations, animal breeding and roosting areas, and 
migration routes), land use history (including present uses and recent past disturbances), and distinct natural features (such as large trees and aquatic areas);

(C) An aerial photograph of the property at an appropriate scale taken as close as possible to the date the donation is made; and

(D) On-site photographs taken at appropriate locations on the property. If the terms of the donation contain restrictions with regard to a particular natural resource to be protected, such as water quality or air quality, the condition of the resource at or near the time of the gift must be established. The documentation, including the maps and photographs, must be accompanied by a statement signed by the donor and a representative of the donee clearly referencing the documentation and in substance saying "This natural resources inventory is an accurate representation of [the protected property] at the time of the transfer.".

(ii) Donee's right to inspection and legal remedies. In the case of any donation referred to in paragraph $(\mathrm{g})(5)(\mathrm{i})$ of this section, the donor must agree to notify the donee, in writing, before exercising any reserved right, e.g. the right to extract certain minerals which may have an adverse impact on the conservation interests associated with the qualified real property interest. The terms of the donation must provide a right of the donee to enter the property at reasonable times for the purpose of inspecting the property to determine if there is compliance with the terms of the donation. Additionally, the terms of the donation must provide a right of the donee to enforce the conservation restrictions by appropriate legal proceedings, including but not limited to, the right to require the restoration of the property to its condition at the time of the donation.

(6) Extinguishment. (i) In general. If a subsequent unexpected change in the conditions surrounding the property that is the subject of a donation under this paragraph can make impossible or impractical the continued use of the property for conservation purposes, the conservation purpose can nonetheless be treated as protected in perpetuity if the restrictions are extinguished by judicial proceeding and all of the donee's proceeds (determined under paragraph (g)(6)(ii) of this section) from a subsequent sale or exchange of the property are used by the donee organization in a manner consistent with the conservation purposes of the original contribution.

(ii) Proceeds. In case of a donation made after February 13, 1986, for a deduction to be allowed under this section, at the time of the gift the donor must agree that the donation of the perpetual conservation restriction gives rise to a property right, immediately vested in the donee organization, with a fair market value that is at least equal to the proportionate value that the perpetual conservation restriction at the time of the gift, bears to the value of the property as a whole at that time. See $\S 1.170 \mathrm{~A}-14(\mathrm{~h})(3)(\mathrm{iii})$ relating to the allocation of basis. For purposes of this paragraph $(g)(6)(i i)$, that proportionate value of the donee's property rights shall remain constant. Accordingly, when a change in conditions give rise to the extinguishment of a perpetual conservation restriction under paragraph $(\mathrm{g})(6)(\mathrm{i})$ of this section, the donee organization, on a subsequent sale, exchange, or involuntary conversion of the subject property, must be entitled to a portion of the proceeds at least equal to that proportionate value of the perpetual conservation restriction, unless state law provides that the donor is entitled to the full proceeds from the conversion without regard to the terms of the prior perpetual conservation restriction. 
(h) Valuation -- (1) Entire interest of donor other than qualified mineral interest. The value of the contribution under section 170 in the case of a contribution of a taxpayer's entire interest in property other than a qualified mineral interest is the fair market value of the surface rights in the property contributed. The value of the contribution shall be computed without regard to the mineral rights. See paragraph (h)(4), example (1), of this section.

(2) Remainder interest in real property. In the case of a contribution of any remainder interest in real property, section $170(f)(4)$ provides that in determining the value of such interest for purposes of section 170, depreciation and depletion of such property shall be taken into account. See $\S$ 1.170A-12. In the case of the contribution of a remainder interest for conservation purposes, the current fair market value of the property (against which the limitations of $\S 1.170 \mathrm{~A}$ 12 are applied) must take into account any pre-existing or contemporaneously recorded rights limiting, for conservation purposes, the use to which the subject property may be put.

(3) Perpetual conservation restriction -- (i) In general. The value of the contribution under section 170 in the case of a charitable contribution of a perpetual conservation restriction is the fair market value of the perpetual conservation restriction at the time of the contribution. See $\S$ $1.170 \mathrm{~A}-7$ (c). If there is a substantial record of sales of easements comparable to the donated easement (such as purchases pursuant to a governmental program), the fair market value of the donated easement is based on the sales prices of such comparable easements. If no substantial record of market-place sales is available to use as a meaningful or valid comparison, as a general rule (but not necessarily in all cases) the fair market value of a perpetual conservation restriction is equal to the difference between the fair market value of the property it encumbers before the granting of the restriction and the fair market value of the encumbered property after the granting of the restriction. The amount of the deduction in the case of a charitable contribution of a perpetual conservation restriction covering a portion of the contiguous property owned by a donor and the donor's family (as defined in section 267(c)(4)) is the difference between the fair market value of the entire contiguous parcel of property before and after the granting of the restriction. If the granting of a perpetual conservation restriction after January 14, 1986, has the effect of increasing the value of any other property owned by the donor or a related person, the amount of the deduction for the conservation contribution shall be reduced by the amount of the increase in the value of the other property, whether or not such property is contiguous. If, as a result of the donation of a perpetual conservation restriction, the donor or a related person receives, or can reasonably expect to receive, financial or economic benefits that are greater than those that will inure to the general public from the transfer, no deduction is allowable under this section. However, if the donor or a related person receives, or can reasonably expect to receive, a financial or economic benefit that is substantial, but it is clearly shown that the benefit is less than the amount of the transfer, then a deduction under this section is allowable for the excess of the amount transferred over the amount of the financial or economic benefit received or reasonably expected to be received by the donor or the related person. For purposes of this paragraph (h)(3)((i), related person shall have the same meaning as in either section $267(b)$ or section 707(b). (See example (10) of paragraph (h)(4) of this section.)

(ii) Fair market value of property before and after restriction. If before and after valuation is used, the fair market value of the property before contribution of the conservation restriction 
must take into account not only the current use of the property but also an objective assessment of how immediate or remote the likelihood is that the property, absent the restriction, would in fact be developed, as well as any effect from zoning, conservation, or historic preservation laws that already restrict the property's potential highest and best use. Further, there may be instances where the grant of a conservation restriction may have no material effect on the value of the property or may in fact serve to enhance, rather than reduce, the value of property. In such instances no deduction would be allowable. In the case of a conservation restriction that allows for any development, however limited, on the property to be protected, the fair market value of the property after contribution of the restriction must take into account the effect of the development. In the case of a conservation easement such as an easement on a certified historic structure, the fair market value of the property after contribution of the restriction must take into account the amount of access permitted by the terms of the easement. Additionally, if before and after valuation is used, an appraisal of the property after contribution of the restriction must take into account the effect of restrictions that will result in a reduction of the potential fair market value represented by highest and best use but will, nevertheless, permit uses of the property that will increase its fair market value above that represented by the property's current use. The value of a perpetual conservation restriction shall not be reduced by reason of the existence of restrictions on transfer designed solely to ensure that the conservation restriction will be dedicated to conservation purposes. See $\S 1.170 A-14$ (c)(3).

(iii) Allocation of basis. In the case of the donation of a qualified real property interest for conservation purposes, the basis of the property retained by the donor must be adjusted by the elimination of that part of the total basis of the property that is properly allocable to the qualified real property interest granted. The amount of the basis that is allocable to the qualified real property interest shall bear the same ratio to the total basis of the property as the fair market value of the qualified real property interest bears to the fair market value of the property before the granting of the qualified real property interest. When a taxpayer donates to a qualifying conservation organization an easement on a structure with respect to which deductions are taken for depreciation, the reduction required by this paragraph (h)(3)(ii) in the basis of the property retained by the taxpayer must be allocated between the structure and the underlying land.

(4) Examples. The provisions of this section may be illustrated by the following examples. In examples illustrating the value or deductibility of donations, the applicable restrictions and limitations of $\S 1.170 \mathrm{~A}-4$, with respect to reduction in amount of charitable contributions of certain appreciated property, and $\S 1.170 \mathrm{~A}-8$, with respect to limitations on charitable deductions by individuals. must also be taken into account.

Example 1. A owns Goldacre, a property adjacent to a state park. A wants to donate Goldacre to the state to be used as part of the park, but A wants to reserve a qualified mineral interest in the property, to exploit currently and to devise at death. The fair market value of the surface rights in Goldacre is $\$ 200,000$ and the fair market value of the mineral rights in $\$ 100.000$. In order to ensure that the quality of the park will not be degraded, restrictions must be imposed on the right to extract the minerals that reduce the fair market value of the mineral rights to $\$ 80,000$. Under this section, the value of the contribution is $\$ 200,000$ (the value of the surface rights). 
Example 2. In 1984 B, who is 62, donates a remainder interest in Greenacre to a qualifying organization for conservation purposes. Greenacre is a tract of 200 acres of undeveloped woodland that is valued at $\$ 200,000$ at its highest and best use. Under $\S 1.170 \mathrm{~A}-12(\mathrm{~b})$, the value of a remainder interest in real property following one life is determined under $\S 25.2512-5$ of this chapter (Gift Tax Regulations). (See $\S 25.2512-5 \mathrm{~A}$ of this chapter with respect to the valuation of annuities, interests for life or term of years, and remainder or reversionary interests transferred before May 1, 1999.) Accordingly, the value of the remainder interest, and thus the amount eligible for an income tax deduction under section $170(\mathrm{f})$, is $\$ 55,996$ (\$200,000 x .27998).

Example 3. Assume the same facts as in example (2), except that Greenacre is B's 200-acre estate with a home built during the colonial period. Some of the acreage around the home is cleared; the balance of Greenacre, except for access roads, is wooded and undeveloped. See section 170(f)(3)(B)(i). However, B would like Greenacre to be maintained in its current state after his death, so he donates a remainder interest in Greenacre to a qualifying organization for conservation purposes pursuant to section $170(f)(3)(B)(i i i)$ and $(h)(2)(B)$. At the time of the gift the land has a value of $\$ 200,000$ and the house has a value of $\$ 100,000$. The value of the remainder interest, and thus the amount eligible for an income tax deduction under section 170(f), is computed pursuant to $\S 1.170 A-12$. See $\S 1.170 A-12(b)(3)$.

Example 4. Assume the same facts as in example (2), except that at age 62 instead of donating a remainder interest B donates an easement in Greenacre to a qualifying organization for conservation purposes. The fair market value of Greenacre after the donation is reduced to $\$$ 110,000 . Accordingly, the value of the easement, and thus the amount eligible for a deduction under section $170(f)$, is $\$ 90,000$ (\$200,000 less $\$ 110,000)$.

Example 5. Assume the same facts as in example (4), and assume that three years later, at age 65, B decides to donate a remainder interest in Greenacre to a qualifying organization for conservation purposes. Increasing real estate values in the area have raised the fair market value of Greenacre (subject to the easement) to $\$ 130,000$. Accordingly, the value of the remainder interest, and thus the amount eligible for a deduction under section $170(f)$, is $\$ 41,639(\$ 130,000$ x.32030).

Example 6. Assume the same facts as in example (2), except that at the time of the donation of a remainder interest in Greenacre, B also donates an easement to a different qualifying organization for conservation purposes. Based on all the facts and circumstances, the value of the easement is determined to be $\$ 100,000$. Therefore, the value of the property after the easement is $\$ 100,000$ and the value of the remainder interest, and thus the amount eligible for deduction under section $170(\mathrm{f})$, is $\$ 27,998$ ( $\$ 100,000 \times$.27998).

Example 7. C owns Greenacre, a 200-acre estate containing a house built during the colonial period. At its highest and best use, for home development, the fair market value of Greenacre is $\$$ 300,000 . C donates an easement (to maintain the house and Green acre in their current state) to a qualifying organization for conservation purposes. The fair market value of Greenacre after the donation is reduced to $\$ 125,000$. Accordingly, the value of the easement and the amount eligible for a deduction under section $170(f)$ is $\$ 175.000$ ( $\$ 300,000$ less $\$ 125,000)$. 
Example 8. Assume the same facts as in example (7) and assume that three years later, C decides to donate a remainder interest in Greenacre to a qualifying organization for conservation purposes. Increasing real estate values in the area have raised the fair market value of Greenacre to $\$ 180.000$. Assume that because of the perpetual easement prohibiting any development of the land, the value of the house is $\$ 120,000$ and the value of the land is $\$ 60,000$. The value of the remainder interest, and thus the amount eligible for an income tax deduction under section 170(f), is computed pursuant to $\S 1.170 \mathrm{~A}-12$. See $\S 1.170 \mathrm{~A}-12(\mathrm{~b})(3)$.

Example 9. D owns property with a basis of $\$ 20,000$ and a fair market value of $\$ 80,000$. D donates to a qualifying organization an easement for conservation purposes that is determined under this section to have a fair market value of $\$ 60,000$. The amount of basis allocable to the easement is $\$ 15,000(\$ 60,000 / \$ 80,000=\$ 15,000 / \$ 20,000)$. Accordingly, the basis of the property is reduced to $\$ 5,000$ ( $\$ 20,000$ minus $\$ 15,000)$.

Example 10. E owns 10 one-acre lots that are currently woods and parkland. The fair market value of each of E's lots is $\$ 15,000$ and the basis of each lot is $\$ 3,000$. E grants to the county a perpetual easement for conservation purposes to use and maintain eight of the acres as a public park and to restrict any future development on those eight acres. As a result of the restrictions, the value of the eight acres is reduced to $\$ 1,000$ an acre. However, by perpetually restricting development on this portion of the land, $\mathrm{E}$ has ensured that the two remaining acres will always be bordered by parkland, thus increasing their fair market value to $\$ 22,500$ each. If the eight acres represented all of $E$ 's land, the fair market value of the easement would be $\$ 112,000$, an amount equal to the fair market value of the land before the granting of the easement $(8 \times \$ 15,000=\$$ $120,000)$ minus the fair market value of the encumbered land after the granting of the easement $(8 \times \$ 1,000=\$ 8,000)$. However, because the easement only covered a portion of the taxpayer's contiguous land, the amount of the deduction under section 170 is reduced to $\$ 97,000$ (\$150,000 - $\$ 53,000)$, that is, the difference between the fair market value of the entire tract of land before $(\$ 150,000)$ and after $((8 \times \$ 1,000)+(2 \times \$ 22,500))$ the granting of the easement.

Example 11. Assume the same facts as in example (10). Since the easement covers a portion of E's land, only the basis of that portion is adjusted. Therefore, the amount of basis allocable to the easement is $\$ 22,400((8 \times \$ 3,000) \times(\$ 112,000 / \$ 120,000))$. Accordingly, the basis of the eight acres encumbered by the easement is reduced to $\$ 1,600(\$ 24,000-\$ 22,400)$, or $\$ 200$ for each acre. The basis of the two remaining acres is not affected by the donation.

Example 12. $\mathrm{F}$ owns and uses as professional offices a two-story building that lies within a registered historic district. F's building is an outstanding example of period architecture with a fair market value of $\$ 125,000$. Restricted to its current use, which is the highest and best use of the property without making changes to the facade, the building and lot would have a fair market value of $\$ 100,000$, of which $\$ 80,000$ would be allocable to the building and $\$ 20,000$ would be allocable to the lot. F's basis in the property is $\$ 50,000$, of which $\$ 40,000$ is allocable to the building and $\$ 10,000$ is allocable to the lot. F's neighborhood is a mix of residential and commercial uses, and it is possible that $\mathrm{F}$ (or another owner) could enlarge the building for more extensive commercial use, which is its highest and best use. However, this would require changes to the facade. $\mathrm{F}$ would like to donate to a qualifying preservation organization an easement restricting any changes to the facade and promising to maintain the facade in perpetuity. The 
donation would qualify for a deduction under this section. The fair market value of the easement is $\$ 25,000$ (the fair market value of the property before the easement, $\$ 125,000$, minus the fair market value of the property after the easement, $\$ 100,000)$. Pursuant to $\S 1.170 \mathrm{~A}-14(\mathrm{~h})(3)(\mathrm{iii})$, the basis allocable to the easement is $\$ 10,000$ and the basis of the underlying property (building and lot) is reduced to $\$ 40,000$.

(i) Substantiation requirement. If a taxpayer makes a qualified conservation contribution and claims a deduction, the taxpayer must maintain written records of the fair market value of the underlying property before and after the donation and the conservation purpose furthered by the donation and such information shall be stated in the taxpayer's income tax return if required by the return or its instructions. See also $\S 1.170 \mathrm{~A}-13$ (c) (relating to substantiation requirements for deductions in excess of \$5,000 for charitable contributions made after 1984), and section 6659 (relating to additions to tax in the case of valuation overstatements).

(j) Effective date. Except as otherwise provided in $\S 1.170 \mathrm{~A}-14(\mathrm{~g})(4)(\mathrm{ii})$, this section applies only to contributions made on or after December 18, 1980. 


\section{Appendix C}

\section{Table of $\S 170(\mathrm{~h})$ Deduction Cases}

\section{Table Structure}

The Table below lists the cases involving challenges to charitable income tax deductions claimed with respect to conservation easement donations. Given that $\S 170(\mathrm{~h})$ and the Treasury Regulations are effective only for transfers made on or after December 18, $1980,{ }^{1}$ the cases are separated into two groups:

1. those involving donations made before the effective date of $\S 170(\mathrm{~h})$ (pre-§ $170(h)$ cases) and

2. those involving donations made on or after the effective date of $\S 170(\mathrm{~h})$ (post-§ 170(h) cases).

Substantial changes were made to the deduction provision with the enactment of $\S 170(\mathrm{~h})$ in 1980. Accordingly, the law in effect on the date of the donation may be an important factor in analyzing the relevance of an older case to a current controversy. ${ }^{2}$

\section{Precedential Value of Tax Court Cases}

The Tax Court issues several different types of opinions, the precedential value of which differs.

1. Summary Opinions. Certain disputes (for example, disputes involving deficiencies of $\$ 50,000$ or less for each year at issue) qualify for simplified or "S case" procedures. The Tax Court generally issues Summary Opinions in these cases, and Summary Opinions cannot be relied on as precedent or appealed.

2. Regular Opinions and Memorandum Opinions. The Tax Court generally issues two types of opinions in cases that are not " $\mathrm{S}$ " cases.

\footnotetext{
${ }^{1}$ Pub. L. 96-541, 94 Stat. 3206, §6(d). Treas. Reg. § 1.170A-14(j). The mortgage subordination, division of proceeds, baseline documentation, and donee notification, access, and enforcement rights requirements apply only to donations made after February 13, 1986. See Treas. Reg. §§ 1.170A-14(g)(2), -14(g)(6)(ii), $14(\mathrm{~g})(5)(\mathrm{i}),-14(\mathrm{~g})(5)(\mathrm{ii})$. The provision requiring a reduction in amount of the donor's deduction for any increase in the value of certain property owned by the donor or a related person as a result of the donation applies only to donations made after January 14, 1986. See id. §1.170A-14(h)(3)(i).

${ }^{2}$ For example, cases involving interpretation of the deduction provision in effect before $\S 170(\mathrm{~h})$ was enacted should not be relied upon in interpreting new requirements added to the deduction provision in 1980 to curb abuses and ensure protection of the federal investment, such as $\S 170(\mathrm{~h})(5)(\mathrm{A})$ 's new "protected-in-perpetuity" requirement. On the other, hand, some of the general rules governing valuation discussed in the older cases are still relevant to current controversies.
} 
a. Opinions, sometimes referred to as "Regular Opinions," (cited as "T.C.") are generally issued in cases that the Tax Court believes involve sufficiently important legal issues or principles. Regular Opinions can be cited as legal authority and appealed, and the Tax Court treats them as binding precedent.

b. Memorandum Opinions (cited at "T.C. Memo.") are generally issued in cases that do not involve novel legal issues and, instead, address situations where the law is settled or factually driven. Memorandum Opinions can be cited as legal authority and appealed, but the Tax Court does not treat them as binding precedent.

The Chief Judge of the Tax Court decides whether an opinion will be issued as a Regular Opinion or a Memorandum Opinion.

3. Bench Opinions. A Tax Court judge is authorized to issue a Bench Opinion in an $\mathrm{S}$ case or a regular case when the judge is "satisfied as to the factual conclusions to be reached in the case and that the law to be applied thereto is clear." To issue a Bench Opinion, the judge orally states the findings of fact and the opinion in court during the trial session and a transcript reflecting the findings of fact and opinion is sent to the parties. Bench Opinions cannot be relied upon as precedent.

\section{Tax Court Opinions}

T.C. and T.C. Memo. Opinions starting 09/25/95 and Summary Opinions starting 01/01/01 are available at https://www.ustaxcourt.gov/UstclnOp/OpinionSearch.aspx. 


\section{Pre- $\$ 170(\mathrm{~h})$ Cases (In Order of Final Opinion Date)}

Date of

Donation

Thayer v. Comm'r, T.C. Memo. 1977-370

1969

Todd v. U.S., 617 F. Supp. 253 (W.D. Pa. 1985)

1979

Hilborn v. Comm'r, 85 T.C. 677 (1985)

1979

Stanley Works v. Comm'r, 87 T.C. 389 (1986)

1977

Akers v. Comm'r, 799 F.2d 243 (6th Cir. 1986),

aff'g T.C. Memo. 1984-490

Symington v. Comm'r, 87 T.C. 892 (1986)

Stotler v. Comm'r, T.C. Memo. 1987-275

1977

Fannon v. Comm'r, 842 F.2d 1290 (4th Cir. 1988) (unpublished), modifying T.C. Memo. 1986-572

Fannon v. Comm'r, T.C. Memo. 1989-136 1979

1979

1979

Dennis v. U.S., 70 A.F.T.R. 2d 92-5946 (E.D. Va. 1992)

McLennan v. U.S., 994 F.2d 839 (Fed. Cir. 1993),

aff'g 24 Cl. Ct. 102 (1991) and 23 Cl. Ct. 99 (1991)

Post- $\S 170(\mathrm{~h})$ Cases (In Order of Final Opinion Date)

$\S 170(\mathrm{~h})$ and the Treasury Regulations are effective only for transfers made on or after Dec. 18, 1980. ${ }^{3}$

\section{8 through 2000}

Nicoladis v. Comm'r, T.C. Memo. 1988-163 1981

Losch v. Comm'r, T.C. Memo. 1988-230 Dec. 24,1980

Richmond v. U.S., 699 F. Supp. 578 (E.D. La. 1988)

Dec. 29,1980

Higgins v. Comm'r, T.C. Memo. 1990-103 1981

Dorsey v. Comm'r, T.C. Memo. 1990-242 1981

Griffin v. Comm'r, 911 F.2d 1124 (5th Cir. 1990), aff'g T.C. Memo. 1989-130

Schapiro v. Comm'r, T.C. Memo. 1991-128 1981

Clemens v. Comm'r, T.C. Memo. 1992-436 1981, 1984

Schwab v. Comm'r, T.C. Memo. 1994-232 1982

Satullo v. Comm'r, 67 F.3d 314, 76 A.F.T.R.2d 6536 (11th Cir. 1995), 1983 aff'g T.C. Memo. 1993-614

Great Northern Nekoosa v. U.S., 38 Fed. Cl. 645 (1997)

Johnston v. Comm'r, T.C. Memo. 1997-475

Browning v. Comm'r, 109 T.C. 303 (1997)

Strasburg v. Comm'r, T.C. Memo. 2000-94

1985

1981

1989

1990

1993, 1994

\footnotetext{
${ }^{3}$ See supra note 1 for exceptions to the effective date for some of the Treasury Regulation provisions.
} 


\begin{tabular}{|c|c|}
\hline \multicolumn{2}{|l|}{2006} \\
\hline Turner v. Comm'r, 126 T.C. 299 (2006) & 1999 \\
\hline Ney v. Comm'r, T.C. Summ. Op. 2006-154 (2006) & 2001 \\
\hline $\begin{array}{l}\text { Glass v. Comm'r, } 471 \text { F.3d } 698 \text { (6th Cir. 2006) (Glass II), } \\
\text { aff'g } 124 \text { T.C. } 258 \text { (2005) (Glass I) }\end{array}$ & 1992,1993 \\
\hline Goldsby v. Comm'r, T.C. Memo. 2006-274 & 2000 \\
\hline \multicolumn{2}{|l|}{2009} \\
\hline Bruzewicz v. U.S., 604 F. Supp. 2d 1197 (N.D. III. 2009) & 2002 \\
\hline Hughes v. Comm'r, T.C. Memo. 2009-94 & 2000 \\
\hline Kiva Dunes v. Comm'r, T.C. Memo. 2009-145 & 2002 \\
\hline \multicolumn{2}{|l|}{$\underline{2010}$} \\
\hline Lord v. Comm'r, T.C. Memo. 2010-196 & 1999 \\
\hline Evans v. Comm'r, T.C. Memo. 2010-207 & 2004 \\
\hline \multicolumn{2}{|l|}{2011} \\
\hline Schrimsher v. Comm'r, T.C. Memo. 2011-71 & 2004 \\
\hline Boltar v. Comm'r, 136 T.C. 326 (2011) & 2003 \\
\hline 1982 East LLC v. Comm'r, T.C. Memo. 2011-84 & 2004 \\
\hline $\begin{array}{l}\text { Comm'r v. Simmons, } 646 \text { F.3d } 6 \text { (D.C. Cir. 2011) (Simmons II), } \\
\text { aff'g Simmons v. Comm'r, T.C. Memo. 2009-208 (Simmons I) }\end{array}$ & 2003,2004 \\
\hline Didonato v. Comm'r, T.C. Memo. 2011-153 & 2004 \\
\hline $\begin{array}{l}\text { Herman v. Comm'r, T.C. Bench Op. (Sept. 22, 2011) (Herman II), } \\
\text { addressing remaining issues in T.C. Memo. 2009-205 (Herman I) }\end{array}$ & 2003 \\
\hline \multicolumn{2}{|l|}{2012} \\
\hline Butler v. Comm'r, T.C. Memo. 2012-72 & 2003,2004 \\
\hline Dunlap v. Comm'r, T.C. Memo. 2012-126 & 2003 \\
\hline Wall v. Comm'r, T.C. Memo. 2012-169 & 2003 \\
\hline Averyt v. Comm'r, T.C. Memo. 2012-198 & 2004 \\
\hline $\begin{array}{l}\text { Rothman v. Comm'r, T.C. Memo. 2012-218 (Rothman II), } \\
\text { vacating in part T.C. Memo. 2012-163 (Rothman I) }\end{array}$ & 2004 \\
\hline $\begin{array}{l}\text { Trout Ranch v. Comm'r, } 493 \text { Fed. Appx. } 944 \text { (10th Cir. 2012) } \\
\text { (unpublished) (Trout Ranch II), } \\
\text { aff'g T.C. Memo. 2010-283 (Trout Ranch I) }\end{array}$ & 2003 \\
\hline Foster v. Comm'r, T.C. Summ. Op. 2012-90 & 2003 \\
\hline Irby v. Comm'r, 139 T.C. 371 (2012) & 2003,2004 \\
\hline \multicolumn{2}{|l|}{2013} \\
\hline Pollard v. Comm'r, T.C. Memo. 2013-38 & 2003 \\
\hline
\end{tabular}




\begin{tabular}{|c|c|}
\hline Graev v. Comm'r, 140 T.C. 377 (2013) & 2004 \\
\hline $\begin{array}{l}\text { Pesky v. U.S., } 2013 \text { WL } 3457691 \text { (D. Idaho, July 8, 2013), } \\
\text { following } 2013 \text { WL } 97752 \text { (D. Idaho, Jan. 7, 2013) }\end{array}$ & 2002 \\
\hline $\begin{array}{l}\text { Carpenter v. Comm'r, T.C. Memo. 2013-172 (Carpenter II), } \\
\text { denying reconsideration of and supplementing T.C. Memo. 2012-1 } \\
\text { (Carpenter I) }\end{array}$ & 2003 \\
\hline $\begin{array}{l}\text { Friedberg v. Comm'r, T.C. Memo. 2013-224 (Friedberg II), } \\
\text { reversing in part and supplementing T.C. Memo. 2011-238 (Friedberg } \\
\text { I) }\end{array}$ & 2003 \\
\hline Gorra v. Comm'r, T.C. Memo. 2013-254 & 2006 \\
\hline 61 York Acquisition, LLC v. Comm'r, T.C. Memo. 2013-266 & 2006 \\
\hline \multicolumn{2}{|l|}{2014} \\
\hline $\begin{array}{l}\text { Esgar Corp. v. Comm'r, } 744 \text { F.3d } 648\left(10^{\text {th }} \overline{\text { Cir. 2014) (Esgar II), }}\right. \\
\text { aff'g T.C. Memo. 2012-35 (Esgar I) and Tempel v. Comm'r, 136 T.C. } \\
341 \text { (2011) }\end{array}$ & 2004 \\
\hline Wachter v. Comm'r, 142 T.C. 140 (2014) & $\begin{array}{l}2004,2005 \\
2006\end{array}$ \\
\hline Chandler v. Comm'r, 142 T.C. 279 (2014) & 2004,2005 \\
\hline $\begin{array}{l}\text { Whitehouse Hotel, LP v. Comm'r, } 755 \text { F.3d } 236 \text { (5 } 5^{\text {th }} \text { Cir. 2014) } \\
\text { (Whitehouse IV), aff'g in part and vacating in part } 139 \text { T.C. } 304 \text { (2012) } \\
\text { (Whitehouse III), on remand from } 615 \text { F.3d } 321 \text { (5th Cir. 2010) } \\
\text { (Whitehouse II), vacating and remanding } 131 \text { T.C. } 112 \text { (2008) } \\
\text { (Whitehouse I) }\end{array}$ & 1997 \\
\hline $\begin{array}{l}\text { Scheidelman v. Comm'r, } 755 \text { F.3d } 148 \text { (2d Cir. 2014) (Scheidelman IV), } \\
\text { aff'g T.C. Memo. 2013-18 (Scheidelman III), on remand from } 682 \text { F.3d } \\
189 \text { (2d Cir. 2012) (Scheidelman II), vacating and remanding T.C. } \\
\text { Memo. 2010-151 (Scheidelman I) }\end{array}$ & 2004 \\
\hline Seventeen Seventy Sherman Street v. Comm'r, T.C. Memo. 2014-124 & 2003 \\
\hline Schmidt v. Comm'r, T.C. Memo. 2014-159 & 2003 \\
\hline Zarlengo v. Comm'r, T.C. Memo. 2014-161 & 2005 \\
\hline Reisner v. Comm'r, T.C. Memo. 2014-230 & 2004 \\
\hline $\begin{array}{l}\text { Belk v. Comm'r, } 774 \text { F.3d } 221 \text { ( } 4^{\text {th }} \text { Cir. 2014) (Belk III), } \\
\text { aff'g T.C. Memo } 2013-154 \text { (Belk II), denying reconsideration of and } \\
\text { supplementing } 140 \text { T.C. } 1 \text { (2013) (Belk I) }\end{array}$ & 2004 \\
\hline \multicolumn{2}{|l|}{2015} \\
\hline $\begin{array}{l}\text { Mitchell v. Comm'r, } 775 \text { F.3d } 1243 \text { (10 }{ }^{\text {th }} \text { Cir. 2015) (Mitchell III), } \\
\text { aff'g T.C. Memo. 2013-204 (Mitchell II), } \\
\text { denying reconsideration and supplementing } 138 \text { T.C. } 324 \text { (2012) } \\
\text { (Mitchell I) }\end{array}$ & 2003 \\
\hline Balsam Mountain v. Comm'r, T.C. Memo. 2015-43 & 2003 \\
\hline
\end{tabular}




\begin{tabular}{|c|c|}
\hline SWF Real Estate LLC v. Comm'r, T.C. Memo. 2015-63 & 2005 \\
\hline $\begin{array}{l}\text { Kaufman v. Comm'r, } 784 \text { F.3d. } 56 \text { (1st Cir. 2015) (Kaufman V), } \\
\text { aff'g T.C. Memo. 2014-52 (Kaufman IV), on remand from } 687 \text { F.3d. } 21 \\
\text { (1st Cir. 2012) (Kaufman III), vacating and remanding in part 136 T.C. } \\
294 \text { (2011) (Kaufman II) and 134 T.C. } 182 \text { (2010) (Kaufman I) }\end{array}$ & 2003 \\
\hline Costello v. Comm'r, T.C. Memo. 2015-87 & 2006 \\
\hline Bosque Canyon Ranch v. Comm'r, T.C. Memo. 2015-130 & $\begin{array}{l}2005 \\
2007\end{array}$ \\
\hline $\begin{array}{l}\text { Minnick v. Comm'r, } 796 \text { F.3d } 1156 \text { (9th Cir. 2015) (Minnick III) and } 611 \\
\text { Fed. Appx. } 477 \text { (9th Cir. 2015) (unpub) (Minnick II), aff'g T.C. Memo. } \\
\text { 2012-345 (Minnick I) }\end{array}$ & 2006 \\
\hline Legg v. Comm'r, 145 T.C. No. 13 (2015) & 2007 \\
\hline Atkinson v. Comm'r, T.C. Memo. 2015-236 & 2003,2005 \\
\hline \multicolumn{2}{|l|}{2016} \\
\hline Gemperle v. Comm'r, T.C. Memo. 2016-1 & 2007 \\
\hline Mecox v. U.S., _ F. Supp. _ (S.D.N.Y. 2016) & 2004 \\
\hline $\begin{array}{l}\text { Palmer Ranch Holdings, Ltd. v. Comm'r, } 812 \text { F.3d } 982\left(11^{\text {th }} \text { Cir. 2016) }\right. \\
\text { (Palmer Ranch II), aff'g in part and reversing and remanding in part, } \\
\text { T.C. Memo 2014-79 (Palmer Ranch I) }\end{array}$ & 2006 \\
\hline French v. Comm'r, T.C. Memo. 2016-53 & 2005 \\
\hline Carroll v. Comm'r, 146 T.C. No. 13 (2016) & 2005 \\
\hline RP Golf, LLC, T.C. Memo. 2016-80 and T.C. Memo. 2012-282 & 2003 \\
\hline $\begin{array}{l}\text { Mountanos v. Comm'r, No. 14-71580 (9th Cir., June 1, 2016) } \\
\text { (unpublished) (Mountanos III), aff'g T.C. Memo. 2013-138 (Mountanos } \\
\text { I), reconsideration denied and opinion supplemented in T.C. Memo. } \\
\text { 2014-38 (Mountanos II). }\end{array}$ & 2005 \\
\hline
\end{tabular}




\section{Appendix D}

\section{Treasury Regulation § 1.170A-13(c)}

Treas. Reg. $\S 1.170 A-13(c)$. Deductions in excess of $\$ 5,000$ for certain charitable contributions of property made after December 31, 1984.

\section{(1) General rule.}

(i) In general. This paragraph applies to any charitable contribution made after December 31, 1984, by an individual, closely held corporation, personal service corporation, partnership, or $\mathrm{S}$ corporation of an item of property (other than money and publicly traded securities to which $\S 1.170 \mathrm{~A}-13(\mathrm{c})(7)(\mathrm{xi})(\mathrm{B})$ does not apply) if the amount claimed or reported as a deduction under section 170 with respect to such item exceeds $\$ 5,000$. This paragraph also applies to charitable contributions by $\mathrm{C}$ corporations (as defined in section 1361(a)(2) of the Code) to the extent described in paragraph (c)(2)(ii) of this section. No deduction under section 170 shall be allowed with respect to a charitable contribution to which this paragraph applies unless the substantiation requirements described in paragraph (c)(2) of this section are met. For purposes of this paragraph (c), the amount claimed or reported as a deduction for an item of property is the aggregate amount claimed or reported as a deduction for a charitable contribution under section 170 for such items of property and all similar items of property (as defined in paragraph (c)(7)(iii) of this section) by the same donor for the same taxable year (whether or not donated to the same donee).

\section{(2) Substantiation requirements.}

(i) In general. Except as provided in paragraph (c)(2)(ii) of this section, a donor who claims or reports a deduction with respect to a charitable contribution to which this paragraph (c) applies must comply with the following three requirements:

(A) Obtain a qualified appraisal (as defined in paragraph (c)(3) of this section) for such property contributed. If the contributed property is a partial interest, the appraisal shall be of the partial interest.

(B) Attach a fully completed appraisal summary (as defined in paragraph (c)(4) of this section) to the tax return (or, in the case of a donor that is a partnership or $S$ corporation, the information return) on which the deduction for the contribution is first claimed (or reported) by the donor. 
(C) Maintain records containing the information required by paragraph (b)(2)(ii) of this section.

\section{(3) Qualified appraisal.}

(i) In general. For purposes of this paragraph (c), the term "qualified appraisal" means an appraisal document that-

(A) Relates to an appraisal that is made not earlier than 60 days prior to the date of contribution of the appraised property nor later than the date specified in paragraph (c)(3)(iv)(B) of this section;

(B) Is prepared, signed, and dated by a qualified appraiser (within the meaning of paragraph (c)(5) of this section);

(C) Includes the information required by paragraph (c)(3)(ii) of this section; and

(D) Does not involve an appraisal fee prohibited by paragraph (c)(6) of this section.

(ii) Information included in qualified appraisal. A qualified appraisal shall include the following information:

(A) A description of the property in sufficient detail for a person who is not generally familiar with the type of property to ascertain that the property that was appraised is the property that was (or will be) contributed;

(B) In the case of tangible property, the physical condition of the property;

(C) The date (or expected date) of contribution to the donee;

(D) The terms of any agreement or understanding entered into (or expected to be entered into) by or on behalf of the donor or donee that relates to the use, sale, or other disposition of the property contributed, including, for example, the terms of any agreement or understanding that-

(1) Restricts temporarily or permanently a donee's right to use or dispose of the donated property, 
(2) Reserves to, or confers upon, anyone (other than a donee organization or an organization participating with a donee organization in cooperative fundraising) any right to the income from the contributed property or to the possession of the property, including the right to vote donated securities, to acquire the property by purchase or otherwise, or to designate the person having such income, possession, or right to acquire, or

(3) Earmarks donated property for a particular use;

(E) The name, address, and (if a taxpayer identification number is otherwise required by section 6109 and the regulations thereunder) the identifying number of the qualified appraiser; and, if the qualified appraiser is acting in his or her capacity as a partner in a partnership, an employee of any person (whether an individual, corporation, or partnerships), or an independent contractor engaged by a person other than the donor, the name, address, and taxpayer identification number (if a number is otherwise required by section 6109 and the regulations thereunder) of the partnership or the person who employs or engages the qualified appraiser;

(F) The qualifications of the qualified appraiser who signs the appraisal, including the appraiser's background, experience, education, and membership, if any, in professional appraisal associations;

(G) A statement that the appraisal was prepared for income tax purposes;

(H) The date (or dates) on which the property was appraised;

(I) The appraised fair market value (within the meaning of $\$ 1.170 \mathrm{~A}$ 1 (c)(2)) of the property on the date (or expected date) of contribution;

(J) The method of valuation used to determine the fair market value, such as the income approach, the market-data approach, and the replacement-cost-less-depreciation approach; and

(K) The specific basis for the valuation, such as specific comparable sales transactions or statistical sampling, including a justification for using sampling and an explanation of the sampling procedure employed.

(iii) Effect of signature of the qualified appraiser. Any appraiser who falsely or fraudulently overstates the value of the contributed property referred to in a qualified appraisal or appraisal summary (as defined in paragraphs (c)(3) and (4), respectively, of this section) that the appraiser has signed may be subject to a 
civil penalty under section 6701 for aiding and abetting an understatement of tax liability and, moreover, may have appraisals disregarded pursuant to 31 U.S.C. $330(c)$.

(iv) Special rules.

(A) Number of qualified appraisals. For purposes of paragraph (c)(2)(i)(A) of this section, a separate qualified appraisal is required for each item of property that is not included in a group of similar items of property. See paragraph (c)(7)(iii) of this section for the definition of similar items of property. Only one qualified appraisal is required for a group of similar items of property contributed in the same taxable year of the donor, although a donor may obtain separate qualified appraisals for each item of property. A qualified appraisal prepared with respect to a group of similar items of property shall provide all the information required by paragraph (c)(3)(ii) of this section for each item of similar property, except that the appraiser may select any items whose aggregate value is appraised at $\$ 100$ or less and provide a group description of such items.

(B) Time of receipt of qualified appraisal. The qualified appraisal must be received by the donor before the due date (including extensions) of the return on which a deduction is first claimed (or reported in the case of a donor that is a partnership or S corporation) under section 170 with respect to the donated property, or, in the case of a deduction first claimed (or reported) on an amended return, the date on which the return is filed.

(C) Retention of qualified appraisal. The donor must retain the qualified appraisal in the donor's records for so long as it may be relevant in the administration of any internal revenue law.

(D) Appraisal disregarded pursuant to 31 U.S.C. 330(c). If an appraisal is disregarded pursuant to 31 U.S.C. 330(c) it shall have no probative effect as to the value of the appraised property. Such appraisal will, however, otherwise constitute a "qualified appraisal" for purposes of this paragraph (c) if the appraisal summary includes the declaration described in paragraph (c)(4)(ii)(L)(2) and the taxpayer had no knowledge that such declaration was false as of the time described in paragraph (c)(4)(i)(B) of this section. 


\section{(4) Appraisal summary.}

(i) In general. For purposes of this paragraph (c), except as provided in paragraph (c)(4)(iv)(A) of this section, the term "appraisal summary" means a summary of a qualified appraisal that-

(A) Is made on the form prescribed by the Internal Revenue Service;

(B) Is signed and dated (as described in paragraph (c)(4)(iii) of this section) by the donee (or presented to the donee for signature in cases described in paragraph (c)(4)(iv)(C)(2) of this section);

(C) Is signed and dated by the qualified appraiser (within the meaning of paragraph (c)(5) of this section) who prepared the qualified appraisal (within the meaning of paragraph (c)(3) of this section); and

(D) Includes the information required by paragraph (c)(4)(ii) of this section.

(ii) Information included in an appraisal summary. An appraisal summary shall include the following information:

(A) The name and taxpayer identification number of the donor (social security number if the donor is an individual or, employer identification number if the donor is a partnership or corporation);

(B) A description of the property in sufficient detail for a person who is not generally familiar with the type of property to ascertain that the property that was appraised is the property that was contributed;

(C) In the case of tangible property, a brief summary of the overall physical condition of the property at the time of the contribution;

(D) The manner of acquisition (e.g., purchase, exchange, gift, or bequest) and the date of acquisition of the property by the donor, or, if the property was created, produced, or manufactured by or for the donor, a statement to that effect and the approximate date the property was substantially completed;

(E) The cost or other basis of the property adjusted as provided by section 1016;

(F) The name, address, and taxpayer identification number of the donee; 
(G) The date the donee received the property;

(H) For charitable contributions made after June 6 1988, a statement explaining whether or not the charitable contribution was made by means of a bargain sale and the amount of any consideration received from the donee for the contribution;

(I) The name, address, and (if a taxpayer identification number is otherwise required by section 6109 and the regulations thereunder) the identifying number of the qualified appraiser who signs the appraisal summary and of other persons as required by paragraph (c)(3)(ii)(E) of this section;

(J) The appraised fair market value of the property on the date of contribution;

(K) The declaration by the appraiser described in paragraph (c)(5)(i) of this section;

(L) A declaration by the appraiser stating that-

(1) The fee charged for the appraisal is not of a type prohibited by paragraph $(e)(6)$ of this section; and

(2) Appraisals prepared by the appraiser are not being disregarded pursuant to 31 U.S.C. 330(c) on the date the appraisal summary is signed by the appraiser; and

(M) Such other information as may be specified by the form.

(iii) Signature of the original donee. The person who signs the appraisal summary for the donee shall be an official authorized to sign the tax or information returns of the donee, or a person specifically authorized to sign appraisal summaries by an official authorized to sign the tax or information returns of such done. In the case of a donee that is a governmental unit, the person who signs the appraisal summary for such donee shall be the official authorized by such donee to sign appraisal summaries. The signature of the donee on the appraisal summary does not represent concurrence in the appraised value of the contributed property. Rather, it represents acknowledgment of receipt of the property described in the appraisal summary on the date specified in the appraisal summary and that the donee understands the information reporting requirements imposed by section $6050 \mathrm{~L}$ and $\S 1.6050 \mathrm{~L}-1$. In general, $\$ 1.6050 \mathrm{~L}-1$ requires the donee to file an information return with the Internal Revenue Service in the event the donee sells, exchanges, consumes, or otherwise disposes 
of the property (or any portion thereof) described in the appraisal summary within 2 years after the date of the donor's contribution of such property.

(iv) Special rules.

(B) Number of appraisal summaries. A separate appraisal summary for each item of property described in paragraph (c)(1) of this section must be attached to the donor's return. If, during the donor's taxable year, the donor contributes similar items of property described in paragraph (c)(1) of this section to more than one donee, the donor shall attach to the donor's return a separate appraisal summary for each donee. See paragraph (c)(7)(iii) of this section for the definition of similar items of property. If, however, during the donor's taxable year, a donor contributes similar items of property described in paragraph (c)(1) of this section to the same donee, the donor may attach to the donor's return a single appraisal summary with respect to all similar items of property contributed to the same donee. Such an appraisal summary shall provide all the information required by paragraph (c)(4)(ii) of this section for each item of property, except that the appraiser may select any items whose aggregate value is appraised at $\$ 100$ or less and provide a group description for such items.

(C) Manner of acquisition, cost basis and donee's signature.

(1) If a taxpayer has reasonable cause for being unable to provide the information required by paragraph (c)(4)(ii)(D) and (E) of this section (relating to the manner of acquisition and basis of the contributed property), an appropriate explanation should be attached to the appraisal summary. The taxpayer's deduction will not be disallowed simply because of the inability (for reasonable cause) to provide these items of information.

(2) In rare and unusual circumstances in which it is impossible for the taxpayer to obtain the signature of the donee on the appraisal summary as required by paragraph $(c)(4)(i)(B)$ of this section, the taxpayer's deduction will not be disallowed for that reason provided that the taxpayer attaches a statement to the appraisal summary explaining, in detail, why it was not possible to obtain the donee's signature. For example, if the donee ceases to exist as an entity subsequent to the date of the contribution and prior to the date when the appraisal summary must be signed, and the donor acted reasonably in not obtaining the donee's signature at 
the time of the contribution, relief under this paragraph (c)(4)(iv)(C)(2) would generally be appropriate.

(D) Information excluded from certain appraisal summaries. The information required by paragraph (c)(4)(i)(C), paragraph (c)(4)(ii)(D), (E), $(\mathrm{H})$ through $(\mathrm{M})$, and paragraph $(\mathrm{c})(4)(\mathrm{iv})(\mathrm{A})(3)$, and the average trading price referred to in paragraph (c)(4)(iv)(A)(4) of this section do not have to be included on the appraisal summary at the time it is signed by the donee or a copy is provided to the donee pursuant to paragraph (c)(4)(iv)(E) of this section.

(E) Statement to be furnished by donors to donees. Every donor who presents an appraisal summary to a donee for signature after June 6, 1988, in order to comply with paragraph (c)(4)(i)(B) of this section shall furnish a copy of the appraisal summary to such donee.

(F) Appraisal summary required to be provided to partners and $S$ corporation shareholders. If the donor is a partnership or S corporation, the donor shall provide a copy of the appraisal summary to every partner or shareholder, respectively, who receives an allocation of a charitable contribution deduction under section 170 with respect to the property described in the appraisal summary.

(G) Partners and S corporation shareholders. A partner of a partnership or shareholder of an $\mathrm{S}$ corporation who receives an allocation of a deduction under section 170 for a charitable contribution of property to which this paragraph (c) applies must attach a copy of the partnership's or S corporation's appraisal summary to the tax return on which the deduction for the contribution is first claimed. If such appraisal summary is not attached, the partner's or shareholder's deduction shall not be allowed except as provided for in paragraph (c)(4)(iv)(H) of this section.

(H) Failure to attach appraisal summary. In the event that a donor fails to attach to the donor's return an appraisal summary as required by paragraph $(\mathrm{c})(2)(\mathrm{i})(\mathrm{B})$ of this section, the Internal Revenue Service may request that the donor submit the appraisal summary within 90 days of the request. If such a request is made and the donor complies with the request within the 90-day period, the deduction under section 170 shall not be disallowed for failure to attach the appraisal summary, provided that the donor's failure to attach the appraisal summary was a good faith omission and the requirements of paragraph (c)(3) and (4) of this section are met (including the completion of the qualified appraisal prior to the date specified in paragraph (c)(3)(iv)(B) of this section). 


\section{(5) Qualified appraiser.}

(i) In general. The term "qualified appraiser" means an individual (other than a person described in paragraph (c)(5)(iv) of this section) who includes on the appraisal summary (described in paragraph (c)(4) of this section), a declaration that-

(A) The individual either holds himself or herself out to the public as an appraiser or performs appraisals on a regular basis;

(B) Because of the appraiser's qualifications as described in the appraisal (pursuant to paragraph (c)(3)(ii)(F) of this section), the appraiser is qualified to make appraisals of the type of property being valued;

(C) The appraiser is not one of the persons described in paragraph (c)(5)(iv) of this section; and

(D) The appraiser understands that an intentionally false or fraudulent overstatement of the value of the property described in the qualified appraisal or appraisal summary may subject the appraiser to a civil penalty under section 6701 for aiding and abetting an understatement of tax liability, and, moreover, the appraiser may have appraisals disregarded pursuant to 31 U.S.C. 330(c) (see paragraph (c)(3)(iii) of this section).

(ii) Exception. An individual is not a qualified appraiser with respect to a particular donation, even if the declaration specified in paragraph (c)(5)(i) of this section is provided in the appraisal summary, if the donor had knowledge of facts that would cause a reasonable person to expect the appraiser falsely to overstate the value of the donated property (e.g., the donor and the appraiser make an agreement concerning the amount at which the property will be valued and the donor knows that such amount exceeds the fair market value of the property).

(iii) Numbers of appraisers. More than one appraiser may appraise the donated property. If more than one appraiser appraises the property, the donor does not have to use each appraiser's appraisal for purposes of substantiating the charitable contribution deduction pursuant to this paragraph (c). If the donor uses the appraisal of more than one appraiser, or if two or more appraisers contribute to a single appraisal, each appraiser shall comply with the requirements of this paragraph (c), including signing the qualified appraisal and appraisal summary as required by paragraphs $(c)(3)(i)(B)$ and $(c)(4)(i)(C)$ of this section, respectively. 
(iv) Qualified appraiser exclusions. The following persons cannot be qualified appraisers with respect to particular property:

(A) The donor or the taxpayer who claims or reports a deductions under section 170 for the contribution of the property that is being appraised.

(B) A party to the transaction in which the donor acquired the property being appraised (i.e., the person who sold, exchanged, or gave the property to the donor, or any person who acted as an agent for the transferor or for the donor with respect to such sale, exchange, or gift), unless the property is donated within 2 months of the date of acquisition and its appraised value does not exceed its acquisition price.

(C) The donee of the property.

(D) Any person employed by any of the foregoing persons (e.g., if the donor acquired a painting from an art dealer, neither the art dealer nor persons employed by the dealer can be qualified appraisers with respect to that painting).

(E) Any person related to any of the foregoing persons under section $267(b)$, or, with respect to appraisals made after June 6, 1988, married to a person who is in a relationship described in section 267 (b) with any of the foregoing persons.

(F) An appraiser who is regularly used by any person described in paragraph (c)(5)(iv)(A), (B), or (C) of this section and who does not perform a majority of his or her appraisals made during his or her taxable year for other persons.

\section{(6) Appraisal fees.}

(i) In general. Except as otherwise provided in paragraph (c)(6)(ii) of this section, no part of the fee arrangement for a qualified appraisal can be based, in effect, on a percentage (or set of percentages) of the appraised value of the property. If a fee arrangement for an appraisal is based in whole or in part on the amount of the appraised value of the property, if any, that is allowed as a deduction under section 170, after Internal Revenue Service examination or otherwise, it shall be treated as a fee based on a percentage of the appraised value of the property. For example, an appraiser's fee that is subject to reduction by the same percentage as the appraised value may be reduced by the Internal Revenue Service would be treated as a fee that violates this paragraph (c)(6). 
(ii) Exception. Paragraph (c)(6)(i) of this section does not apply to a fee paid to a generally recognized association that regulates appraisers provided all of the following requirements are met:

(A) The association is not organized for profit and no part of the net earnings of the association inures to the benefit of any private shareholder or individual (these terms have the same meaning as in section 501(c)),

(B) The appraiser does not receive any compensation from the association or any other persons for making the appraisal, and

(C) The fee arrangement is not based in whole or in part on the amount of the appraised value of the donated property, if any, that is allowed as a deduction under section 170 after Internal Revenue Service examination or otherwise.

(7) Meaning of terms. For purposes of this paragraph(c)- 
Appendix E

Internal Revenue Code $\S 170(f)(11)$

IRC $\S 170$ Charitable, etc., contributions and gifts.

$\cdots$

(f) Disallowance of deduction in certain cases and special rules.

- .

(11) Qualified appraisal and other documentation for certain contributions.

(A) In general.

(i) Denial of deduction. In the case of an individual, partnership, or corporation, no deduction shall be allowed under subsection (a) for any contribution of property for which a deduction of more than $\$ 500$ is claimed unless such person meets the requirements of subparagraphs (B), (C), and (D), as the case may be, with respect to such contribution.

(ii) Exceptions.

(I) Readily valued property. Subparagraphs (C) and (D) shall not apply to cash, property described in subsection (e)(1)(B)(iii) or section 1221(a)(1), publicly traded securities (as defined in section $6050 \mathrm{~L}(\mathrm{a})(2)(\mathrm{B}))$, and any qualified vehicle described in paragraph (12)(A)(ii) for which an acknowledgement under paragraph (12)(B)(iii) is provided.

(II) Reasonable cause. Clause (i) shall not apply if it is shown that the failure to meet such requirements is due to reasonable cause and not to willful neglect.

(B) Property description for contributions of more than $\$ 500$. In the case of contributions of property for which a deduction of more than $\$ 500$ is claimed, the requirements of this subparagraph are met if the individual, partnership or corporation includes with the return for the taxable year in which the contribution is made a description of such property and such other information as the Secretary may require. The requirements of this subparagraph shall not apply to a $\mathrm{C}$ corporation which is not a personal service corporation or a closely held $\mathrm{C}$ corporation.

(C) Qualified appraisal for contributions of more than $\$ 5,000$. In the case of contributions of property for which a deduction of more than $\$ 5,000$ is claimed, 
the requirements of this subparagraph are met if the individual, partnership, or corporation obtains a qualified appraisal of such property and attaches to the return for the taxable year in which such contribution is made such information regarding such property and such appraisal as the Secretary may require.

(D) Substantiation for contributions of more than $\$ 500,000$. In the case of contributions of property for which a deduction of more than $\$ 500,000$ is claimed, the requirements of this subparagraph are met if the individual, partnership, or corporation attaches to the return for the taxable year a qualified appraisal of such property.

(E) Qualified appraisal and appraiser. For purposes of this paragraph-

(i) Qualified appraisal. The term 'qualified appraisal' means, with respect to any property, an appraisal of such property which-

(I) is treated for purposes of this paragraph as a qualified appraisal under regulations or other guidance prescribed by the Secretary, and

(II) is conducted by a qualified appraiser in accordance with generally accepted appraisal standards and any regulations or other guidance prescribed under subclause (I).

(ii) Qualified appraiser. Except as provided in clause (iii), the term 'qualified appraiser' means an individual who-

(I) has earned an appraisal designation from a recognized professional appraiser organization or has otherwise met minimum education and experience requirements set forth in regulations prescribed by the Secretary,

(II) regularly performs appraisals for which the individual receives compensation, and

(III) meets such other requirements as may be prescribed by the Secretary in regulations or other guidance.

(iii) Specific appraisals. An individual shall not be treated as a qualified appraiser with respect to any specific appraisal unless-

(I) the individual demonstrates verifiable education and experience in valuing the type of property subject to the appraisal, and

(II) the individual has not been prohibited from practicing before the Internal Revenue Service by the Secretary under section 330(c) of title 31, United States Code, at any time during the 3year period ending on the date of the appraisal.

(F) Aggregation of similar items of property. For purposes of determining 
thresholds under this paragraph, property and all similar items of property donated to 1 or more donees shall be treated as 1 property.

(G) Special rule for pass-thru entities. In the case of a partnership or $S$ corporation, this paragraph shall be applied at the entity level, except that the deduction shall be denied at the partner or shareholder level.

(H) Regulations. The Secretary may prescribe such regulations as may be necessary or appropriate to carry out the purposes of this paragraph, including regulations that may provide that some or all of the requirements of this paragraph do not apply in appropriate cases. 


\section{Appendix F}

\section{IRS Form 8283 (appraisal summary) and Supplemental Statement}

\section{Rule 1: Contiguous Parcel}

Treas. Reg. § 1.170A-14(h)(3)(i) - $4^{\text {th }}$ sentence

If land contiguous to the land encumbered by the easement is owned by the donor or a member of the donor's family, the deduction is equal to the difference between the before-easement and aftereasement values of the entire contiguous parcel.

The family of an individual shall include only his brothers and sisters (whether by the whole or half blood), spouse, ancestors, and lineal descendants. 


\section{Rule 2: Enhancement}

Treas. Reg. § 1.170A-14(h)(3)(i) - $5^{\text {th }}$ sentence.

If the easement enhances the value of any other property owned by the donor or a "related person," the donor's deduction must be reduced by an amount equal to the value of any such enhancement, whether or not such other property is contiguous.

"Related person" is defined to include family members and certain entities

\section{IRS Form 8283 \\ Noncash Charitable Contributions}

Filling out the form correctly and completely ...

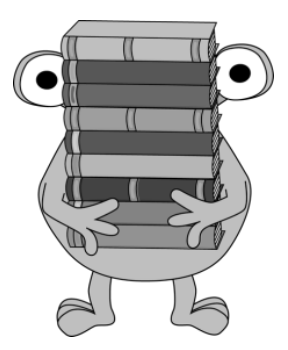

Appendix F 


\section{Example 1: Simple Donation}

\begin{tabular}{|l|}
\hline \multicolumn{2}{|c|}{ CE Protected Land } \\
\hline \begin{tabular}{lll}
\hline Before easement value: & $\$ 1,000,000$ \\
After easement value: & $\$ 700,000$ \\
\hline Easement value: & $\$ 300,000$ \\
\hline
\end{tabular} \\
\hline
\end{tabular}

Deduction is

$\$ 300,000$

\section{Example 1: Simple Donation}

Before easement value: $\$ 1,000,000$

After easement value: $\$ 700,000$

Easement value: $\$ 300,000$

Part I Information on Donated Property-To be completed by the taxpayer and/or the appraiser.

4 Check the box that describes the type of property donated:

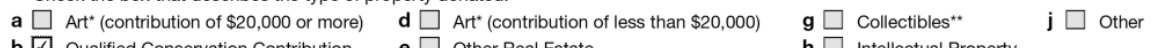

b $\square$ Qualified Conservation Contribution $\quad$ e $\square$ Other Real Estate $\quad \mathbf{h} \square$ Intellectual Property

c $\square$ Equipment $\quad$ f $\square$ Securities $\quad$ i $\square$ Vehicles

"Art includes paintings, sculptures, watercolors, prints, drawings, ceramics, antiques, decorative arts, textiles, carpets, silver, rare manuscripts, historical memorabilia, and other similar objects.

"Collectibles include coins, stamps, books, gems, jewelry, sports memorabilia, dolls, etc., but not art as defined above.

Note. In certain cases, you must attach a qualified appraisal of the property. See instructions.

\begin{tabular}{|c|c|c|c|c|c|c|}
\hline 5 & \multicolumn{2}{|c|}{$\begin{array}{l}\text { (a) Description of donated property (if you need } \\
\text { more space, attach a separate statement) }\end{array}$} & \multicolumn{3}{|c|}{$\begin{array}{l}\text { (b) If tangible property was donated, give a brief summary of the overall } \\
\text { physical condition of the property at the time of the gift }\end{array}$} & $\begin{array}{l}\text { (c) Appraised fair } \\
\text { market value }\end{array}$ \\
\hline A & \multicolumn{5}{|c|}{ Conservation easement (IRC 170(h)) on 300 acres } & $\$ 300,000$ \\
\hline B & \multicolumn{6}{|c|}{ in Bath County, VA to protect open space. } \\
\hline C & \multicolumn{6}{|c|}{ See attached supplemental statement and Deed } \\
\hline \multirow[t]{3}{*}{ D } & \multicolumn{6}{|l|}{ of Easement } \\
\hline & \multirow{2}{*}{$\begin{array}{l}\text { (d) Date acquired } \\
\text { by donor (mo., yr.) }\end{array}$} & \multirow{2}{*}{ (e) How acquired by donor } & \multirow{2}{*}{$\begin{array}{l}\text { (f) Donor's cost or } \\
\text { adjusted basis }\end{array}$} & \multirow{2}{*}{\begin{tabular}{|c|} 
(g) For bargain sales, enter \\
amount received
\end{tabular} \mid} & \multicolumn{2}{|c|}{ See instructions } \\
\hline & & & & & $\begin{array}{l}\text { (h) Amount claimed as a } \\
\text { deduction as }\end{array}$ & (i) Date of contribution \\
\hline A & August 2005 & Purchase & $\$ 750,000$ & & & \\
\hline B & (date donor & (how donor acquired the (pr & e-contrib. basis & & & \\
\hline C & acquired the & underlying property) & underlying prop & & & \\
\hline D & underlying prop.) & & see supp. stmt) & & & \\
\hline
\end{tabular}

Appendix F 


\section{Example 2: Simple Bargain Sale}

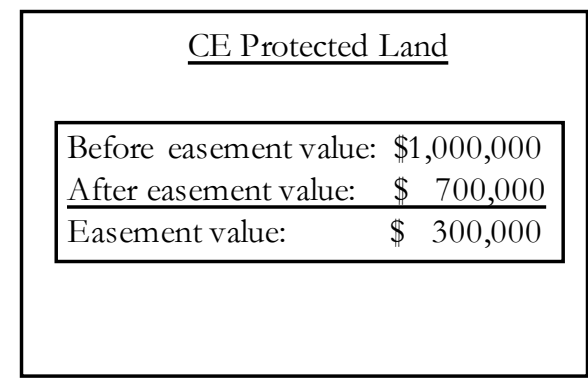

Landowner is paid $\$ 150,000$ for easement

Deduction is $\$ 150,000$

\section{Example 2: Simple Bargain Sale}

\begin{tabular}{|l|l|}
\hline Before easement value: & $\$ 1,000,000$ \\
After easement value: & $\$ 700,000$ \\
\hline Easement value: & $\$ 300,000$ \\
\hline
\end{tabular}

Landowner is paid $\$ 150,000$ for easement

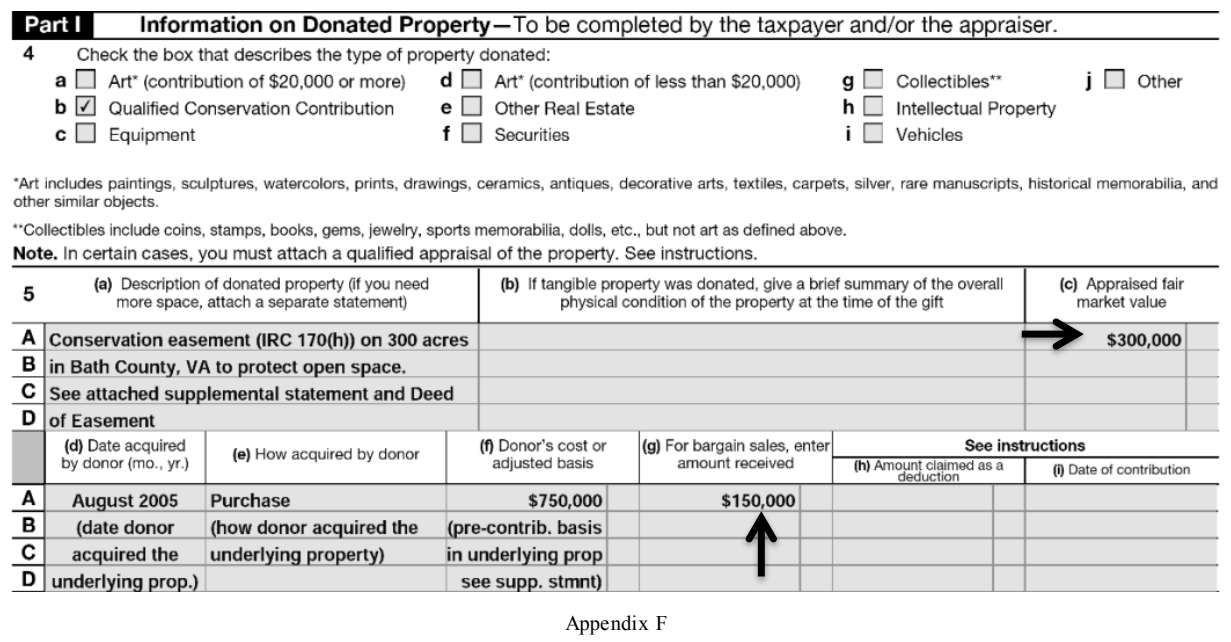




\title{
Example 3: Rule 1 Contiguous Parcel
}

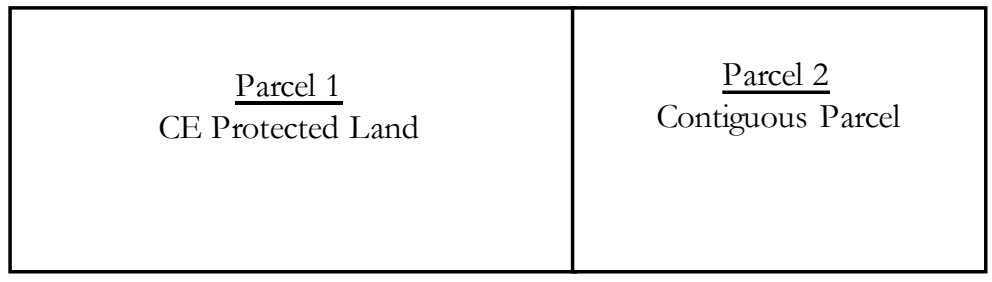

Before-easement value of entire contiguous parcel: $\$ 1,500,000$

After-easement value of entire contiguous parcel: \$ $\$ 900,000$

Easement value: $\$ 600,000$

Deduction is

$\$ 600,000$

Appendix

\section{Example 3: Rule 1 Contiguous Parcel}

\author{
Before easement value of entire contiguous parcel: $\$ 1,500,000$ \\ After easement value of entire contiguous parcel: \$900,000 \\ Easement value: $\$ 600,000$
}

Part I Information on Donated Property-To be completed by the taxpayer and/or the appraiser.

$4 \quad$ Check the box that describes the type of property donated:

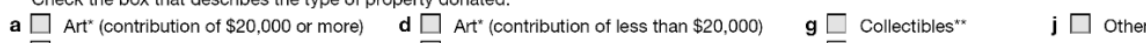

b $\square$ Qualified Conservation Contribution $\quad$ e $\square$ Other Real Estate $\quad$ h $\square$ Intellectual Property

c $\square$ Equipment $\quad$ f $\square$ Securities $\quad$ i $\square$ Vehicles

-Art includes paintings, sculptures, watercolors, prints, drawings, ceramics, antiques, decorative arts, textles, carpets, silver, rare manuscripts, historical memorabilia, and ther similar objects.

"Collectibles include coins, stamps, books, gems, jewelry, sports memorabilia, dolls, etc., but not art as defined above. Note. In certain cases, you must attach a qualified appraisal of the property. See instructions.

\begin{tabular}{|c|c|c|c|c|c|c|c|}
\hline 5 & \multicolumn{3}{|c|}{$\begin{array}{l}\text { (a) Description of donated property (if you need } \\
\text { more space, attach a separate statement) }\end{array}$} & \multicolumn{3}{|c|}{$\begin{array}{l}\text { (b) If tangible property was donated, give a brief summary of the overall } \\
\text { physical condition of the property at the time of the gift }\end{array}$} & $\begin{array}{l}\text { (c) Appraised fair } \\
\text { market value }\end{array}$ \\
\hline A & \multicolumn{3}{|c|}{ Conservation easement (IRC 170(h)) on 300 acres } & & & & $\$ 600,000$ \\
\hline B & \multicolumn{3}{|c|}{ in Bath County, VA to protect open space. } & & & & \\
\hline C & \multicolumn{3}{|c|}{ See attached supplemental statement and Deed } & & & & \\
\hline \multirow[t]{3}{*}{ D } & \multicolumn{3}{|l|}{ of Easement } & & & & \\
\hline & \multirow{2}{*}{$\begin{array}{l}\text { (d) Date acquired } \\
\text { by donor (mo., yr.) }\end{array}$} & \multirow{2}{*}{ (e) How acquired by donor } & \multirow{2}{*}{\multicolumn{2}{|c|}{$\begin{array}{l}\text { (f) Donor's cost or } \\
\text { adjusted basis }\end{array}$}} & \multirow{2}{*}{$\begin{array}{c}\text { (g) For bargain sales, enter } \\
\text { amount received }\end{array}$} & \multicolumn{2}{|c|}{ See instructions } \\
\hline & & & & & & $\begin{array}{l}\text { (h) Amount claimed as a } \\
\text { deduction }\end{array}$ & (i) Date of contribution \\
\hline A & August 2005 & Purchase & & $\$ 750,000$ & & & \\
\hline B & (date donor & (how donor acquired the & (pre & -contrib. basis & & & \\
\hline C & acquired the & underlying property) & in $u$ & nderlying prop & & & \\
\hline D & underlying prop.) & & & supp. stmnt) & & & \\
\hline
\end{tabular}




\section{IRS Chief Counsel Memorandum 201334039 Footnote 1}

"Whether the entire contiguous parcel is valued as one large property or as separate properties depends on the [HBU] of the entire contiguous parcel."

\section{Example 4: Rule 2 Enhancement}

\begin{tabular}{|l|}
\hline \multicolumn{2}{|c|}{ CE Protected Land } \\
\hline \begin{tabular}{ll}
\hline Before easement value: & $\$ 1,000,000$ \\
After easement value: & $\$ 700,000$ \\
\hline Easement value: $\quad \$ \quad 300,000$ \\
\hline
\end{tabular} \\
\hline
\end{tabular}

Noncontiguous Parcel

value enhanced $\$ 50,000$ by easement donation

Deduction is $\$ 250,000$ 


\section{Example 4: Rule 2 Enhancement}

\begin{tabular}{|ll|}
\hline Before easement value: & $\$ 1,000,000$ \\
After easement value: & $\$ 700,000$ \\
\hline Easement value: & $\$ 300,000$ \\
\hline
\end{tabular}

CE enhances value

of noncontiguous

parcel by $\$ 50,000$
*Address $\$ 50,000$

Enhancement in

Supplemental Statement

Part I Information on Donated Property-To be completed by the taxpayer and/or the appraiser.

4 Check the box that describes the type of property donated:

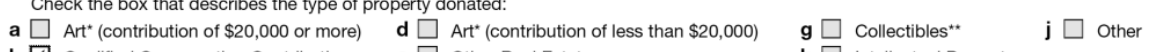

b $\square$ Qualified Conservation Contribution $\quad$ e $\square$ Other Real Estate $\quad$ h $\square$ Intellectual Property

c $\square$ Equipment $\quad$ f $\square$ Securities $\quad$ i $\square$ Vehicles

"Art includes paintings, sculptures, watercolors, prints, drawings, ceramics, antiques, decorative arts, textiles, carpets, silver, rare manuscripts, historical memorabilia, and other similar objects.

"Collectibles include coins, stamps, books, gems, jewelry, sports memorabilia, dolls, etc., but not art as defined above. Note. In certain cases, you must attach a qualified appraisal of the property. See instructions.

\begin{tabular}{|c|c|c|c|c|c|c|c|}
\hline 5 & \multicolumn{3}{|c|}{$\begin{array}{l}\text { (a) Description of donated property (if you need } \\
\text { more space, attach a separate statement) }\end{array}$} & \multicolumn{3}{|c|}{$\begin{array}{l}\text { (b) If tangible property was donated, give a brief summary of the overall } \\
\text { physical condition of the property at the time of the gift }\end{array}$} & $\begin{array}{l}\text { (c) Appraised fair } \\
\text { market value }\end{array}$ \\
\hline A & \multicolumn{3}{|c|}{ Conservation easement (IRC 170(h)) on 300 acres } & & & & $\$ 300,000$ \\
\hline B & \multicolumn{3}{|c|}{ in Bath County, VA to protect open space. } & & & & \\
\hline C & \multicolumn{3}{|c|}{ See attached supplemental statement and Deed } & & & & \\
\hline \multirow[t]{3}{*}{ D } & \multicolumn{3}{|l|}{ of Easement } & & & & \\
\hline & \multirow{2}{*}{$\begin{array}{l}\text { (d) Date acquired } \\
\text { by donor (mo., yr.) }\end{array}$} & \multirow{2}{*}{ (e) How acquired by donor } & \multirow{2}{*}{\multicolumn{2}{|c|}{$\begin{array}{l}\text { (f) Donor's cost or } \\
\text { adjusted basis }\end{array}$}} & \multirow{2}{*}{$\begin{array}{c}\text { (g) For bargain sales, enter } \\
\text { amount received }\end{array}$} & \multicolumn{2}{|c|}{ See instructions } \\
\hline & & & & & & (h) Amount claimed as a & (i) Date of contribution \\
\hline A & August 2005 & Purchase & & $\$ 750,000$ & & & \\
\hline B & (date donor & (how donor acquired the & (pr & e-contrib. basis & & & \\
\hline C & acquired the & underlying property) & in 4 & underlying prop & & & \\
\hline D & underlying prop.) & & & see supp. stmt) & & & \\
\hline
\end{tabular}

Appendix F

Part III Declaration of Appraiser

declare that I am not the donor, the donee, a party to the transaction in which the donor acquired the property, employed by, or related to any of the foregoing persons, or married to any person who is related to any of the foregoing persons. And, if regularly used by the donor, donee, or party to the transaction, I performed the majority of my eppraisals during my tax year for other persons.

Also, I declare that I perform appraisals on a regular basis; and that because of my qualifications as described in the appraisal, I am qualified to make appraisals of the type of property being valued. I certify that the appraisal fees were not based on a percentage of the appraised property value. Furthermore, I Inderstand that a false or fraudulent overstatement of the property
alue as described in the qualified appraisal or this Form 8283 may subiect me to the penalty under section 6701 (a) (aiding and abetting the understatement of tax liability). In addition, I

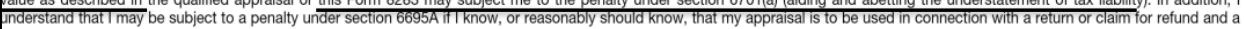
substantial or gross valuation misstatement results from my appraisal. I affirm that I have not been barred from presenting evidence or testimony by the Office of Professional Responsibility. Sign Mike Roman Sam Roman

Here Signature Mike Roman SamRoman Title President; Associate Darch 14, 2015 \begin{tabular}{|l|l|l|l|l|l}
\hline Pusiness address (including room or suite no.) & Identifying number \\
\hline
\end{tabular}

\begin{tabular}{|r|r|}
\hline M. Roman \& Associates Appraisal Co., 5 Main Street & $12-1234567$
\end{tabular} City or town, state, and ZIP code

lexington, Virginia 24450

Treas. Reg. § 1.170A-13(c)(5)(iii)

If two or more appraisers contribute to a single appraisal, each appraiser must comply with the [Treasury Regulation requirements] ..., including signing the qualified appraisal and appraisal summary. 


\section{Appendix G}

Name(s) shown on income tax return

Identifying Number

Robert T. Landowner

021-34-1234

Susan B. Landowner

083-23-5555

\section{IRS FORM 8283 \\ SUPPLEMENTAL STATEMENT DONATION OF CONSERVATION EASEMENT}

On November 12, 2010, the taxpayers/donors completed the donation of a conservation easement (in Massachusetts, a "conservation restriction") under the provisions of Section 170(h) of the Internal Revenue Code of 1986, as amended, and the regulations thereunder (the "Code"). The conservation restriction encumbers 55 acres, more or less (the "Property"), of a larger parcel of 65 acres, more or less, owned by the taxpayers in the Town of Barnstable, Barnstable County, Massachusetts.

Pursuant to the Treasury Regulations, the value of the conservation restriction was determined by appraising all of the contiguous property owned by the donors before and after the conservation restriction.

There are currently no residences or other habitable dwellings on the encumbered Property. The conservation restriction prohibits any commercial or industrial activities, or the construction of any new residence or habitable dwelling, on the Property. The donation was made to the Barnstable Land Trust (the "donee"), a "qualified organization" as defined at Section 170(h) of the Code.

The Property is within (i) the Barnstable Harbor/Sandy Neck Area of Critical Environmental Concern; (ii) a Massachusetts Natural Heritage and Endangered Species Program Priority Habitat for rare and endangered species; and (iii) a Massachusetts Department of Fisheries, Wildlife and Environmental Law Enforcement BioMap Core Habitat area and a BioMap Supporting Natural Landscape area, all as further described below. Further, the Property is within areas declared by the Town of Barnstable and the Cape Cod Regional Policy Plan as important and deserving of protection and preservation, as further described below.

The donation will protect a number of important conservation values, including the following:

according to the Baseline Documentation Report, certified by the donors and the donee as accurate as of the effective date of the conservation restriction, the Property encompasses salt marsh, tidal creek, coastal bank, cultural field, pine-oak woodland and maple/blueberry swamp habitats; and 
the Commonwealth of Massachusetts, through the authority of the Secretary of Energy and Environmental Affairs under General Law Chapter 21A, Section 2(7) may designate Areas of Critical Environmental Concern ("ACEC"), which are places in Massachusetts that receive special recognition because of the quality, uniqueness and significance of their natural and cultural resources; and,

the 1997 Massachusetts Coastal Zone Management Plan promotes a Protected Areas Policy \#1 to preserve, restore, and enhance complexes of coastal resources of regional or statewide significance through the Areas of Critical Environmental Concern program; and,

in 1978, the Barnstable Harbor/Sandy Neck ecosystem in the Towns of Barnstable and Sandwich was designated as an Area of Critical Environmental Concern (ACEC); and,

the Property is located within the Barnstable Harbor/Sandy Neck ACEC, and a copy of the Massachusetts Geographic Information System (MassGIS) map of such ACEC, showing the location of the Property, is included in the Baseline Documentation; and,

the Massachusetts Endangered Species Act, M.G.L. c. 131A, protects rare species and their habitats, and the Massachusetts Natural Heritage and Endangered Species Program ("MNHESP") has designated as Priority Habitats the known geographical extent of habitat for state-listed rare plant and animal species; and,

the Property is located within an MNHESP Priority Habitat for rare and endangered species, and a copy of the MassGIS map of such Priority Habitats, showing the location of the Property, is included in the Baseline Documentation; and,

in 2001 the Massachusetts Department of Fisheries, Wildlife and Environmental Law Enforcement published a report entitled BioMap: Guiding Land Conservation for Biodiversity in Massachusetts, which identified critical habitat "areas, that if protected, would provide suitable habitat over the long term for the maximum number of Massachusetts' terrestrial and wetland plant, animal species, and natural communities;" and developed a BioMap to identify the areas most in need of protection in order to protect the native biodiversity of the Commonwealth; and,

the BioMap contains Core Habitat areas, which depict the most viable habitats for rare species and natural communities in Massachusetts, and Supporting Natural Landscape areas, which buffer and connect Core Habitat areas and which identify large, naturally vegetated blocks that are relatively free from the impact of roads and other development; and,

the Property is located within a BioMap Core Habitat area and a BioMap Supporting Natural Landscape area, and a copy of the MassGIS map of such BioMap areas, showing the location of the Property, is included in the Baseline Documentation; and, 
in 1998, MNHESP published a report entitled Our Irreplaceable Heritage: Protecting Biodiversity in Massachusetts, which stated, "We believe that [there are] eight ecosystem types or natural community assemblages [that are] the most important targets for biodiversity conservation. They represent the most threatened or ecologically essential areas for rare plants and animals in Massachusetts," (p. 29) and specifically identified coastal natural communities as standing out "as some of the most biologically diverse lands in the Commonwealth" and singled out salt marsh in particular as important to conserve and restore (p. 30), and the Property contains approximately 4.49 acres of salt marsh habitat; and,

in 2003, a Statewide Land Conservation Plan was drafted, which identifies the most significant available, undeveloped and unprotected open space lands needed to protect, among other things, biodiversity habitats; and,

the Property is included in the Statewide Land Conservation Plan, and a copy of the MassGIS map of such Statewide Land Conservation Plan, showing the location of the Property, is included in the Baseline Documentation; and,

the 1997 Massachusetts Coastal Zone Management Plan promotes a Coastal Hazards Policy\#1 to preserve, protect, restore, and enhance the beneficial functions of storm damage prevention and flood control provided by natural coastal landforms, such as dunes, beaches, barrier beaches, coastal banks, land subject to coastal storm flowage, salt marshes, and land under the ocean; and,

the Property consists of coastal banks, land subject to coastal storm flowage, salt marshes and land under the ocean and lies partially within FEMA Zone $\mathrm{A}$ and Zone $\mathrm{V}$ coastal floodplain, a high hazard area, and a copy of the official FEMA flood insurance rate map, showing the location of the Property, is included in the Baseline Documentation; and,

in August 2001, the Association for the Preservation of Cape Cod (APCC) produced a map depicting, among other things, residential land of 2.5 acres or more on which a potential conservation restriction could be placed, and the Property is identified on APCC's map as falling within this category; and,

in 2003, The Compact of Cape Cod Conservation Trusts, Inc. completed its Cape Cod Wildlife Conservation Project ("Wildlife Project"), a wildlife habitat analysis and parcel ranking for all vacant or underdeveloped parcels on Cape Cod, Massachusetts; and,

the Property was included in the Wildlife Project, and was ranked "High" in terms of its habitat protection priority, and "Maximum," the highest possible ranking, in terms of its wildlife habitat value; and, 
the Town of Barnstable developed a Local Comprehensive Plan, approved by the Cape Cod Commission in 1998, which plan's stated objectives included, among other things:

- To "preserve and improve the ecological integrity of fresh surface water bodies and marine waters" (Goal 2.1.1; p.2-13);

- To "minimize contamination of water resources with nitrogen, in order to maintain...the ecological integrity of streams, ponds and coastal embayments" (Goal 2.1.3; p. 2-23);

- To "preserve and restore the area, quality and functions of Barnstable's coastal and inland wetlands" (Goal 2.3.1; p.2-86);

- To "prevent loss or degradation of critical wildlife and plant habitat, to minimize the impact of new development on wildlife and plant habitat, to maintain existing populations and species diversity, and to maintain areas which will support wildlife's natural breeding, feeding and migration patterns" (Goal 2.4.1; p.2-93);

- To "protect and increase the wildlife population and habitats of Barnstable" (Goal 6.5; p.6-22) and "preserve those wildlife corridors that foster diversity of habitat and link known wildlife resource areas"(Policy 6.5.1; p. 6-22);

- To "encourage the preservation of open space...through creative means of conservation restrictions"(Goal 6.1.2; p. 6-13); and

- To "identify, protect and preserve Barnstable's historic...landscapes and archaeological resources" (Goal 7.5; page 7-24); and,

the Local Comprehensive Plan included a Greenbelt and Fingerlinks Corridors Map identifying potential parcels of vacant and underdeveloped land for its creation, and a map identifying Archaeological Sensitivity Areas; and,

the Property is identified on the Greenbelt and Fingerlinks Corridors Map as one of the potential parcels for the creation of such corridor within the Town of Barnstable; and,

the Property is located within a Town of Barnstable primary area of archaeological sensitivity, defined as an area within 1000 feet of a marine or marine related ecosystem and which has a high probability of containing prehistoric archaeological sites; and,

the Town of Barnstable developed an Open Space Plan (1984, amended 1987, 1998, and 2005) with a goal of preserving "quality open spaces throughout the Town which protect and enhance its visual heritage..." and which identified, among other things, the following community objectives:

- To acquire, retain, preserve and protect a maximum amount of open space for 
the community and its natural and wildlife habitats (Goal 1, 2005), with priorities focused on, among things, lands adjacent to designated protected or potential open space, lands adjacent to wetlands, and lands providing wildlife corridors, including areas within and abutting Core Habitats identified by the Massachusetts Natural Heritage and Endangered Species Program, and encourage the use of creative regulatory and non-regulatory land protection tools such as conservation restrictions;

- To protect the environmental health of Barnstable's surface water resources (Goal 2, 2005);

- To protect and enhance Barnstable's unique and fragile natural and cultural resources including scenic beauty, historic areas and unique habitats (Goal 6, 2005);

- To protect and increase wildlife population and habitats (Goal 10, 2005); and,

in 1981 the Town of Barnstable adopted a Conservation Restriction Program consisting of policies and guidelines, in particular an Open Space Policy, approved by the Board of Selectmen, Assessors and Conservation Commission, which encourages the use of conservation restrictions in perpetuity to protect natural resources in accordance with the purposes of the Open Space Plan, and which further specified that purposes of a conservation restriction could include the following:

- prevent disturbance of wetlands,

- preserve open space,

- preserve important natural habitats of fish, wildlife or plants,

- protect marine water quality,

- limit or prevent construction on land of natural resource value; and,

in July, 1991, the Barnstable Assembly of Delegates, pursuant to the Cape Cod Commission Act (Chapter 716 of the Acts of 1989), adopted a Regional Policy Plan, amended in 1996 and further amended in 2002 and 2009 , which provided, inter alia (references are to the 2009 Plan):

- a Wetlands Goal to "preserve and restore the quality and quantity of inland and coastal wetlands and their buffers on Cape Cod" (p.52);

- a Wildlife and Plant Habitat Goal to "prevent loss or degradation of critical wildlife and plant habitat, to minimize the adverse impact of new development on wildlife and plant habitat and to maintain existing populations and species diversity" (p. 55), stating that "renewed commitment to protect the most ecologically sensitive undeveloped lands through land acquisition and other permanent conservation measures is also warranted"; 
- an Open Space and Recreation Goal to "preserve and enhance the availability of open space that provides wildlife habitat...and protects the region's natural resources and character" (p.57), with a recommended Town Action of working with "local land conservation organizations to identify, acquire by fee simple or conservation restriction, and manage open space to meet projected community needs. Priority should be given "to the protection of significant natural and fragile areas as identified on the Cape Cod Significant Natural Resources Areas map." (p.58); and,

- a Heritage Preservation/Community Character Goal to "protect and preserve the important historic and cultural features of Cape Cod's landscape...that are critical components of the region's heritage and economy" (p. 80); and,

the Regional Policy Plan includes a Significant Natural Resources Areas Map, which shows, among other things, rare species habitat, priority natural communities, wetlands, and critical upland areas; and,

the Property is located within a Regional Policy Plan Significant Natural Resource Area, and a copy of the map, showing the location of the Property, is included in the Baseline Documentation; and,

the Great and General Court of Massachusetts established the Old Kings Highway Regional Historic District on the northern shore of Barnstable County through Chapter 740 of the Acts of 1973; and,

the Property is located on the north side of Route $6 \mathrm{~A}$ within the Old Kings Highway Regional Historic District; and,

the Property is visible from Barnstable Harbor, the Great Marsh and Sandy Neck, and therefore is seen by Barnstable residents and tourists on a regular basis; and,

the Property is a substantial contributing element to the overall scenic and cultural character of the area by maintaining the land predominantly in its natural condition.

Therefore, the conservation purposes under Section $170(\mathrm{~h})$ of the Code furthered by the donation of the conservation restriction include the following: (i) the preservation of significant relatively natural habitat of plants and similar ecosystems, under Section 170(h)(4)(A)(ii); (ii) the preservation of open space for the scenic enjoyment of the general public, which yields a significant public benefit, under Section $170(\mathrm{~h})(4))(\mathrm{A})(\mathrm{iii})(\mathrm{I})$; and (iii) the preservation of open space pursuant to clearly delineated local governmental policy, which yields a significant public benefit, under Section 170(h)(4)(A)(iii)(II). 
The taxpayers acquired a portion of the property by purchase in 1996, and other portions of the property by gift, beginning in the 1970s. Therefore, the taxpayers are unable at this time to determine with accuracy the basis of the Property.

Applying the Direct Sales Comparison Approach combined with the Cost of Development or "Subdivision" Approach, the appraisers concluded that the market value of the conservation restriction was derived as follows:

a. Market value of the entire contiguous 65 acres before donation of the conservation restriction: $\$$

b. Market value of the entire contiguous 65 acres after donation of the conservation restriction: $\$$

c. Market value of the conservation restriction: $\$$

A copy of the qualified appraisal that substantiates these values and verifies the appraisal methodology is filed with this Form 8283 and the donor's tax return. A copy of the recorded conservation restriction is included in the appraisal report.

Neither the donors, related family members, nor related entities (as defined by the Treasury Regulations) own any other contiguous property or nearby property the value of which is enhanced by the donation of this conservation restriction, so no further adjustment was required to the conclusion of value. The donation of the conservation restriction was not made to obtain a permit or other approval from a local or other governing authority, nor was the donation required by any contractual obligation. The Property was not encumbered by a mortgage at the time of the donation of the conservation restriction.

The condition of the Property was documented and established through extensive baseline documentation acknowledged by the donors and the donee as an accurate representation of the condition of the Property on the effective date of the donation. The Baseline Documentation Report is filed with this Form 8283 and the donor's tax return, as is a copy of the letter from the donee to the taxpayers sent pursuant to the provisions of Section 170(f)(8) of the Code.

The conservation restriction was recorded on November 12, 2010, at the Barnstable County Registry of Deeds, Barnstable County, Massachusetts. 


\section{Appendix H}

\section{McLaughlin Blog Posts on Case Law and Other Developments (with live links to sources)}

\section{$\S 170(h)$ Deduction Cases}

Atkinson v. Comm'r-Golf Course Conservation Easements Not Deductible http://bit.ly/1RHkbyN

Balsam Mountain v. Comm'r-Conservation Easement Authorizing Limited Swaps Not Deductible

http://bit.ly/1VMeyyh

Belk v. Comm'r-4th Circuit Confirms Swappable Conservation Easements Are Not Deductible http://bit.ly/1SGLYPI

Bosque Canyon Ranch v. Comm'r-Partnerships Denied Deductions for Conservation Easements Allowing Movable Homesites and Taxed on Disguised Sales of Homesites http://bit.ly/1V3PVPb

Carroll v. Comm'r-Conservation Easement Deduction Denied for Noncompliant "Proceeds" Clause http://bit.ly/1QFURnr

Carpenter v. Comm'r Revisited-Federally-Deductible Conservation Easements Extinguishable Only in a Judicial Proceeding http://bit.ly/1mDKVDj

Chandler v. Comm'r-Façade Easements Had No Value and Strict Liability Penalty Applied for 2006

http://bit.ly/1oi4L8n

Esgar v. Comm'r-10th Circuit Affirms Tax Court: Conservation Easements Were Overvalued, Income From State Tax Credit Sales Was Short Term Capital Gain http://bit.ly/1okBOZU

French v. Comm'r-Conservation Easement Deduction Denied for Lack of Contemporaneous Written Acknowledgment http://bit.ly/1RjMJxP

Friedberg v. Comm'r Revisited-Questionable Appraisal Can Be a "Qualified Appraisal" http://bit.ly/1LqltHU 
Gemperle v. Comm'r-Tax Court Denies Deduction for Façade Easement Donation For Failure to Include Appraisal In Tax Return Filing

http://bit.ly/1SPSPrR

Gorra v. Comm'r-Facade Easement Deductible but Gross Valuation Misstatement Penalty Applied http://bit.ly/1KSn7qO

Graev v. Comm'r -Side Letter Kills Deductions for a Façade Easement Donation http://bit.ly/1QhD4sW

Kaufman v. Comm'r (Again)-Façade Easement Had No Value and Penalties Imposed http://bit.ly/245TpoA

Legg v. Comm'r-Conservation Easement Donor Liable for Gross Valuation Misstatement Penalties

http://bit.ly/1PXxj1t

Mecox v. U.S-District Court Denies Deduction for Façade Easement Donation; Deed Recorded in Wrong Year and Appraisal Untimely

http://bit.ly/1PWHK7t

Minnick v. Comm'r - 9th Circuit Affirms Tax Court, Mortgages Must Be Subordinated When Conservation Easement is Donated http://bit.ly/1oOOrNa

Minnick v. Comm'r-9th Circuit's Unpublished Holdings in Conservation Easement Donation Case

http://bit.ly/24uler2

Mitchell v. Comm'r - 10th Circuit Affirms Tax Court, Mortgages Must Be Subordinated When Conservation Easement is Donated http://bit.ly/1UqGae3

Mitchell v. Comm'r Revisited-170(h) Requires Perpetuation of Conservation Easement Itself, Not Just Conservation Purposes

http://bit.ly/1Ralthg

Mountanos v. Comm'r-9th Circuit Affirmed Tax Court's Denial of Conservation Easement Donation Deductions and Imposition of Penalties

http://bit.ly/1Ultilv 
Palmer Ranch v. Comm'r-11th Circuit Remands Conservation Easement Valuation to Tax Court

http://bit.ly/1U4cJOQ

Pesky v. U.S. -Deduction for Conservation Easement Donation Not Fraudulent http://bit.ly/1Qk55OB

Pollard v. Comm'r-Conservation Easement Conveyed For Quid Pro Quo Not Deductible http://bit.ly/21q7Dlx

Reisner v. Comm'r -Strict Liability Penalty for Facade Easement Deduction http://bit.ly/1QNPV6y

RP Golf, LLC v. Comm'r-Conservation Easement Deduction Denied Because Mortgages Not Subordinated at Time of Donation

http://bit.ly/1TIfzL3

Scheidelman v. Comm'r (Again)-Second Circuit Affirms Tax Court's Holding that Façade Easement Had No Value http://bit.ly/1Qk5fpm

Scheidelman v. Comm'r-A Long Journey to the Denial of a Deduction for a Facade Easement Donation http://bit.ly/1pfAFDg

Schmidt v. Comm'r-Conservation Easement Overvalued But No Penalties Imposed http://bit.ly/1n4TdUY

Seventeen Seventy Sherman Street, LLC v. Comm'r -Conservation Easement Conveyed for Quid Pro Quo Not Deductible and Negligence Penalty Applied http://bit.ly/1QmGQw3

SWF Real Estate v. Comm'r-Special Allocation of Tax Credit Generated by Conservation Easement Donation was Disguised Sale, but Easement Valuation Largely Upheld http://bit.ly/1ODrHEq

Wachter v. Comm'r - North Dakota Conservation Easements Not Deductible http://bit.ly/1Qb3MR0

Whitehouse Hotel v. Comm'r (Again) - 5th Circuit Affirms Tax Court's Façade Easement Valuation But Vacates on Penalties http://bit.ly/1Ramk1n 
Zarlengo v. Comm'r-Conservation Easement Overvalued and Not Protected In Perpetuity Until Recorded

http://bit.ly/1TJVUJO

61 York Acquisition, LLC v. Comm'r $-\$ 10.7 m$ Facade Easement Deduction Denied for Failure to Restrict Entire Exterior

http://bit.ly/21q8fHQ

Other Federal Tax-Related Issues

Conservation Easements and the Valuation Conundrum

http://bit.ly/1S8qThA

Enhanced Incentives for Easement Donations Made Permanent Without Reforms http://bit.ly/1oOPJb1

IRS on Conservation Easement Appraisals

http://bit.ly/1UqHbTI

IRS Chief Counsel Memorandum Addresses Conservation Easement Valuation http://bit.ly/1pfBQ5t

IRS Rules Tax-Exempt Status of Organization Accepting Conservation Easements Should be Revoked

http://bit.ly/1XRv4ic

IRS Bars Appraisers from Valuing Facade Easements for Five Years http://bit.ly/1Ran1rs

Façade Easement Appraiser Barred From Preparing Appraisal Reports and Ordered to Turn Over List of Clients

http://bit.ly/1n4UDPt

Income From Charitable Organization's Sale of Mitigation Bank Credits is not Unrelated Business Taxable Income

http://bit.ly/1WQSF1g

Route 231, LLC v. Comm'r-4th Circuit Affirms Allocation of $97 \%$ of Tax Credits Generated by Conservation Donations to $1 \%$ Partner Was Disguised Sale http://bit.ly/1JZOJvQ 
Keeping the Perpetual in Perpetual Conservation Easements http://bit.ly/1Qk6pB5

Montana Trial Court Upholds TNC's Enforcement of a Conservation Easement http://bit.ly/1KSEOSF

Conservation Easement Valid Despite Referencing Incorrect Grantor http://bit.ly/1n4UZp9

Register v. TNC - \$1 Million Donation Constituted a Restricted Charitable Gift http://bit.ly/24umlad

Maryland Appellate Court Upholds Conservation Easement http://bit.ly/1RanqKo

Maryland Land Trust and Attorney General Enforce a Conservation Easement http://bit.ly/1RanvxJ

ME Supreme Court: Conservation Lands Open to Public Exempt from Property Tax http://bit.ly/1Qb4dul

MA Supreme Court: Conservation Land Open to Public Exempt from Property Tax http://bit.ly/1Rvro2T

Glass v. Van Lokeren-Conservation Easement Donors Sue Land Trust http://bit.ly/1Qb4a1I

Growing Marijuana as "Agriculture" on Conservation-Easement Protected Land http://bit.ly/1S8qH10

Federally-Funded Conservation Easement Thwarts Marijuana Production http://bit.ly/1Qk5KzR

Symposium

Perpetual Conservation Easements: What Have We Learned and Where Should We Go From Here?

http://bit.ly/1KSDeVJ 